Prepared in cooperation with the National Park Service

\title{
Ambient and Potential Denitrification Rates in Marsh Soils of Northeast Creek and Bass Harbor Marsh Watersheds, Mount Desert Island, Maine
}

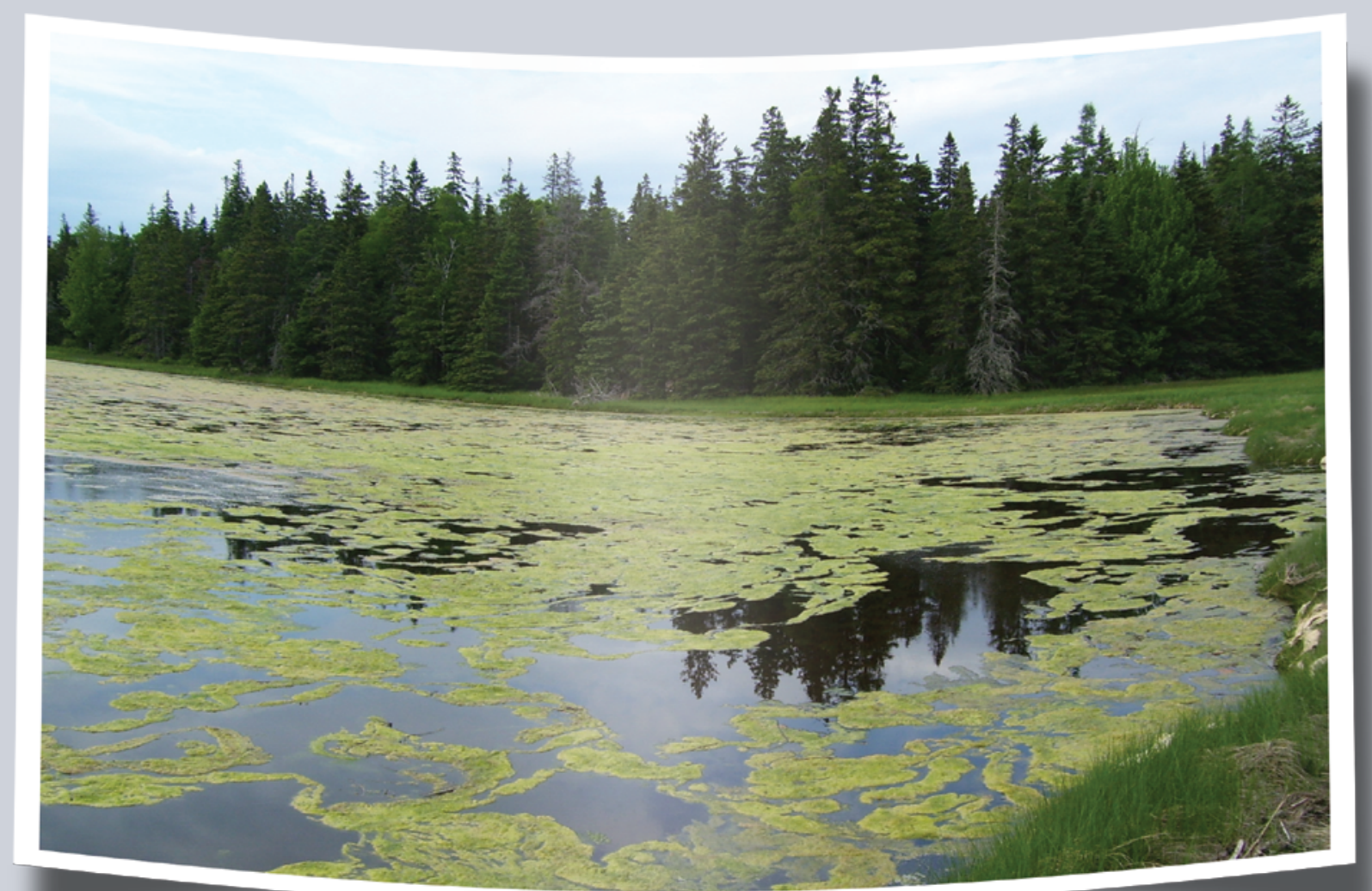

Scientific Investigations Report 2012-5166 
Cover. Extensive nuisance algal bloom in the Bass Harbor Marsh estuary on June 9, 2008. (Photograph by Thomas G. Huntington) 


\section{Ambient and Potential Denitrification Rates in Marsh Soils of Northeast Creek and Bass Harbor Marsh Watersheds, Mount Desert Island, Maine}

By Thomas G. Huntington, Charles W. Culbertson, and John H. Duff

Prepared in cooperation with the National Park Service

Scientific Investigations Report 2012-5166 


\title{
U.S. Department of the Interior \\ KEN SALAZAR, Secretary \\ U.S. Geological Survey \\ Marcia K. McNutt, Director
}

\author{
U.S. Geological Survey, Reston, Virginia: 2012
}

For more information on the USGS - the Federal source for science about the Earth, its natural and living resources, natural hazards, and the environment, visit http://www.usgs.gov or call 1-888-ASK-USGS.

For an overview of USGS information products, including maps, imagery, and publications, visit http://www.usgs.gov/pubprod

To order this and other USGS information products, visit http://store.usgs.gov

Any use of trade, firm, or product names is for descriptive purposes only and does not imply endorsement by the U.S. Government.

Although this information product, for the most part, is in the public domain, it also may contain copyrighted materials as noted in the text. Permission to reproduce copyrighted items must be secured from the copyright owner.

Suggested citation:

Huntington, T.G., Culbertson, C.W., and Duff, J.H., 2012, Ambient and potential denitrification rates in marsh soils of Northeast Creek and Bass Harbor Marsh watersheds, Mount Desert Island, Maine: U.S. Geological Survey Scientific Investigations Report 2012-5166, 40 p., at http://pubs.usgs.gov/sir/2012/5166/. 


\section{Contents}

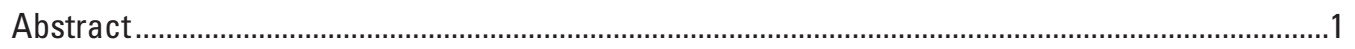

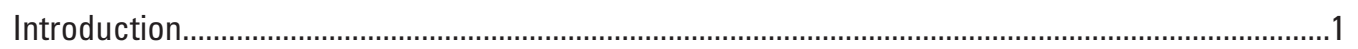

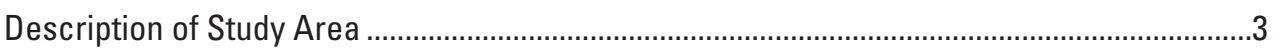

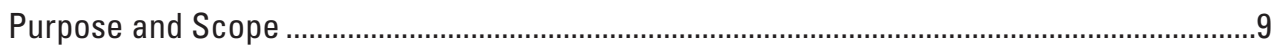

Field Denitrification Methods...................................................................................................

Laboratory Denitrification Methods ………………............................................................11

Laboratory $\mathrm{N}_{2} \mathrm{O}$ Analytical Methods and Computation of $\mathrm{N}_{2} \mathrm{O}$ Release Rate ..................................12

Field Methods for Water Quality Sampling and Measurements.....................................................12

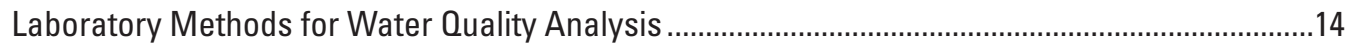

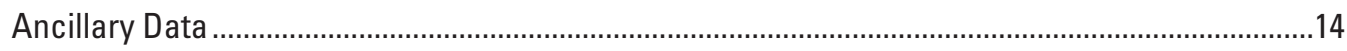

Laboratory Denitrification Experiments to Determine $\mathrm{N}_{2}$ to $\mathrm{N}_{2} \mathrm{O}$ Ratios ..........................................15

Laboratory Denitrification Experiments to Determine Response to Nitrate and

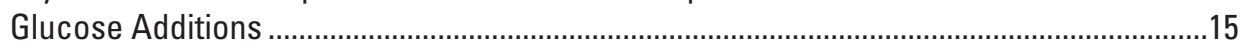

Field Measurements of Denitrification Under Ambient Conditions...............................................19

Field Measurements of Denitrification Following Nitrate and Glucose Addition Treatments ........23

Field Denitrification Rate in Relation to Environmental Variables .................................................35

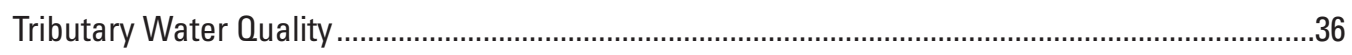

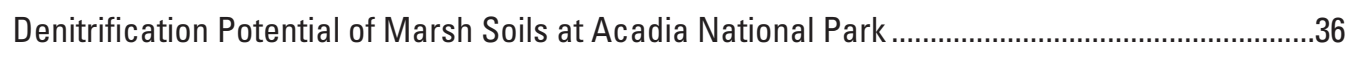

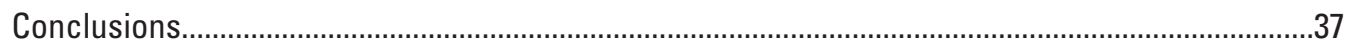

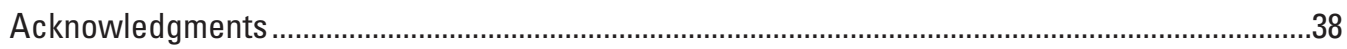

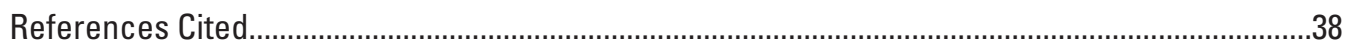

\section{Figures}

1. Shaded relief map showing the locations of the study areas, including the Northeast Creek (NEC) and Bass Harbor Marsh (BHM) watersheds on Mount Desert Island, Maine.

2. Map showing Northeast Creek watershed area, Mount Desert Island, Maine, and surface-water sampling locations on the major tributaries and the location of a groundwater monitoring well

3. Aerial map showing the locations of denitrification measurement sites and groundwater sampling wells in Northeast Creek watershed, Mount Desert Island, Maine...

4. Map showing the location of Bass Harbor Marsh watershed, Mount Desert Island, Maine, and surface-water sampling locations on the major tributaries.

5. Aerial map showing the locations of denitrification measurement sites and groundwater sampling wells in Bass Harbor Marsh watershed, Mount Desert Island, Maine.

6. Bar graphs showing production rates of nitrous oxide in the laboratory determined after the indicated incubation intervals with $A$, no glucose added and $B$, glucose added at 3.6 grams per square meter of fresh soil

7. Boxplots showing laboratory nitrous oxide production rates following nitrate, glucose, and acetylene addition treatment additions after the indicated incubation intervals for $A$, Northeast Creek watershed sites GW2, GW3, and GW5 and $B$, Bass Harbor Marsh watershed sites GW1, GS2, and GW3 
8. Boxplots showing $A$, average of the field denitrification rates for sites GW4 and GW2, July 2008 in the Northeast Creek watershed. $B$, Average of the field denitrification rates for sites GW1-GW6, July and August 2009 in the Bass Harbor Marsh watershed.

9. Graphs showing $A$, water levels in the Fresh Meadow Marsh, Northeast Creek watershed, Mount Desert Island, Maine, and discharge at Otter Creek U.S. Geological Survey (USGS) streamgage 01022840; and B, daily precipitation at the McFarland Hill weather station, near Bar Harbor, Mount Desert Island, Maine..

10. Graph showing average rate of denitrification over the measurement period from 3 hours 5 minutes to 20 hours 32 minutes after sealing chamber to marsh sediment surface at Bass Harbor Marsh watershed site GW2 in June 2009

11. Graph showing average rate of denitrification over measurement period from 4 hours 33 minutes to 22 hours 32 minutes after sealing chamber to marsh sediment surface at Bass Harbor Marsh watershed site GW3 in June 2009

12. Graph showing average rate of denitrification over measurement period from 4 hours 22 minutes to 22 hours 01 minutes after sealing chamber to marsh sediment surface on Bass Harbor Marsh watershed site GW4 in July 2009.

13. Graph showing average rate of denitrification over measurement period from 5 hours 8 minutes to 22 hours 43 minutes after sealing chamber to marsh sediment surface on Bass Harbor Marsh watershed site GW6 in July 2009.

14. Graph showing average rate of denitrification over measurement period from 4 hours 27 minutes to 19 hours 32 minutes after sealing chamber to marsh sediment surface at Bass Harbor Marsh watershed site GW5 in August 2009.

15. Graph showing average rate of denitrification over measurement period from 2 hours 51 minutes to 26 hours 16 minutes after sealing chamber to marsh sediment surface at Northeast Creek watershed site GW4 in September 2009.

16. Graphs showing relation between field denitrification rate and headspace nitrous oxide concentration and the varying incubation intervals once the chamber was sealed to the marsh surface at the Northeast Creek watershed site GW4 in September 2009, immediately following the following treatment additions: $A, 1.1$ grams of nitrogen per square meter only; $B, 1.1$ grams of nitrogen per square meter plus 3.6 grams of glucose per square meter; $C, 5.5$ grams of nitrogen per square meter only; $D, 5.5$ grams of nitrogen per square meter plus 3.6 grams of glucose per square meter; $E, 11$ grams of nitrogen per square meter; $F, 11$ grams of nitrogen per square meter plus 3.6 grams of glucose per square meter; $G, 22$ grams of nitrogen per square meter; $H, 22$ grams of nitrogen per square meter plus 3.6 grams of glucose per square meter; $I, 55$ grams of nitrogen per square meter; and $J, 55$ grams of nitrogen per square meter plus 3.6 grams of glucose per square meter

17. Graphs showing relation between field denitrification rate and headspace nitrous oxide concentration and the varying incubation intervals once the chamber was sealed to the marsh surface at the Bass Harbor Marsh watershed site GW4 in September 2009, immediately following the following treatment additions: $A, 1.1$ grams of nitrogen per square meter only; $B, 1.1$ grams of nitrogen per square meter plus 3.6 grams of glucose per square meter; $C, 5.5$ grams of nitrogen per square meter only; $D, 5.5$ grams of nitrogen per square meter plus 3.6 grams of glucose per square meter; $E, 11$ grams of nitrogen per square meter; $F, 11$ grams of nitrogen per square meter plus 3.6 grams of glucose per square meter; $G, 22$ grams of nitrogen per square meter; $H, 22$ grams of nitrogen per square meter plus 3.6 grams of glucose per square meter; I, 55 grams of nitrogen per square meter; $J, 55$ grams of nitrogen per square meter plus 3.6 grams of glucose per square meter; $K, 110$ grams of nitrogen per square meter; and $L, 110$ grams of nitrogen per square meter plus 3.6 grams of glucose per square meter 


\section{Tables}

1. Dates of field (in situ) denitrification rate measurements, locations of measurements, and treatments applied on measurement dates...........................................................10

2. Surface water and groundwater water-quality monitoring stations in Northeast Creek and Bass Harbor Marsh watersheds sampled in 2008 and 2009.

3. Constituent name, U.S. Geological Survey National Water Information System parameter codes and method codes, and minimum reporting limits for temperature, specific conductance, dissolved oxygen, and nutrients...

4. Ratios of $\mathrm{N}_{2}$ to $\mathrm{N}_{2} \mathrm{O}$ denitrification products measured in laboratory incubation experiments using acetylene to block production of $\mathrm{N}_{2}$

5. Denitrification rates for each month, year, and site under ambient (no treatment additions) and following treatments where nitrate was added alone or in combination with glucose

6. Denitrification rates in paired measurements under ambient or glucose only addition.

7. Pearson correlation coefficients between denitrification rate and the noted variables under experimental conditions where low levels of nitrate were added and no glucose was added..

8. Mean and standard errors of nutrient concentrations in tributaries to Northeast

Creek and Bass Harbor Marsh.

\section{Conversion Factors, Datum, and Abbreviations}

Inch/Pound to SI

\begin{tabular}{|c|c|c|}
\hline Multiply & By & To obtain \\
\hline \multicolumn{3}{|c|}{ Length } \\
\hline foot (ft) & 0.3048 & meter $(\mathrm{m})$ \\
\hline inch (in.) & $3.937 \times 10^{-5}$ & micrometer $(\mu)$ \\
\hline inch (in.) & 25.4 & millimeter (mm) \\
\hline inch (in.) & 2.54 & centimeter $(\mathrm{cm})$ \\
\hline mile (mi) & 1.609 & kilometer (km) \\
\hline \multicolumn{3}{|c|}{ Area } \\
\hline acre & 4,047 & square meter $\left(\mathrm{m}^{2}\right)$ \\
\hline square mile $\left(\mathrm{mi}^{2}\right)$ & 2.590 & square kilometer $\left(\mathrm{km}^{2}\right)$ \\
\hline square foot $\left(\mathrm{ft}^{2}\right)$ & 0.09290 & square meter $\left(\mathrm{m}^{2}\right)$ \\
\hline \multicolumn{3}{|c|}{ Volume } \\
\hline gallon (gal) & 3.785 & liter (L) \\
\hline ounce, fluid (fl. oz) & 29.57 & milliliter $(\mathrm{mL})$ \\
\hline cubic inch $\left(\right.$ in $\left.^{3}\right)$ & 16.39 & cubic centimeter $\left(\mathrm{cm}^{3}\right)$ \\
\hline \multicolumn{3}{|c|}{ Mass } \\
\hline ounce, avoirdupois (oz) & 28.35 & gram (g) \\
\hline ounce, avoirdupois (oz) & 0.02835 & milligram (mg) \\
\hline \multicolumn{3}{|c|}{ Application rate } \\
\hline $\begin{array}{l}\text { ounce, avoirdupois per square yard } \\
\left(\mathrm{oz} / \mathrm{yd}^{2}\right)\end{array}$ & 0.02949 & $\begin{array}{l}\text { grams per square meter } \\
\left(\mathrm{g} / \mathrm{m}^{2}\right)\end{array}$ \\
\hline
\end{tabular}


Temperature in degrees Celsius $\left({ }^{\circ} \mathrm{C}\right)$ may be converted to degrees Fahrenheit $\left({ }^{\circ} \mathrm{F}\right)$ as follows:

$$
{ }^{\circ} \mathrm{F}=\left(1.8 x^{\circ} \mathrm{C}\right)+32
$$

Temperature in degrees Fahrenheit $\left({ }^{\circ} \mathrm{F}\right)$ may be converted to degrees Celsius $\left({ }^{\circ} \mathrm{C}\right)$ as follows:

$$
{ }^{\circ} \mathrm{C}=\left({ }^{\circ} \mathrm{F}-32\right) / 1.8
$$

Vertical coordinate information is referenced to the North American Vertical Datum of 1988 (NAVD 88).

Horizontal coordinate information is referenced to the North American Datum of 1983 (NAD 83).

Specific conductance is given in microsiemens per centimeter at 25 degrees Celsius $(\mu \mathrm{S} / \mathrm{cm}$ at $\left.25^{\circ} \mathrm{C}\right)$.

Concentrations of chemical constituents in water are given either in milligrams per liter ( $\mathrm{mg} / \mathrm{L}$ ) or micrograms per liter ( $\mu \mathrm{g} / \mathrm{L})$.

\section{Abbreviations}

BMH Bass Harbor Marsh

NADP National Atmospheric Deposition Program

NEC Northeast Creek Estuary

NPS National Park Service

USGS U.S. Geological Survey 


\title{
Ambient and Potential Denitrification Rates in Marsh Soils of Northeast Creek and Bass Harbor Marsh Watersheds, Mount Desert Island, Maine
}

\author{
By Thomas G. Huntington, Charles W. Culbertson, and John H. Duff
}

\section{Abstract}

Nutrient enrichment from atmospheric deposition, agricultural activities, wildlife, and domestic sources is a concern at Acadia National Park on Mount Desert Island, Maine, because of the potential problems of degradation of water quality and eutrophication in estuaries. Degradation of water quality has been observed at Bass Harbor Marsh estuary in the park but only minimally in Northeast Creek estuary. Previous studies at Acadia National Park have estimated nutrient inputs to estuaries from atmospheric deposition and surface-water runoff, and have identified shallow groundwater as an additional potential source of nutrients. Previous studies at Acadia National Park have assumed that a certain fraction of the nitrogen input was removed through microbial denitrification, but rates of denitrification (natural or maximum potential) in marsh soils have not been determined. The U.S. Geological Survey, in cooperation with Acadia National Park, measured in-place (in-situ) denitrification rates in marsh soils in Northeast Creek and in Bass Harbor Marsh watersheds during summer 2008 and summer 2009. Denitrification was measured under ambient conditions as well as after additions of inorganic nitrogen and glucose.

In-place denitrification rates under ambient conditions were similar to those reported for other coastal wetlands, although they were generally lower than those reported for salt marshes having high ambient concentrations of nitrate $\left(\mathrm{NO}_{3}\right)$. Denitrification rates generally increased by at least an order of magnitude following $\mathrm{NO}_{3}$ additions, with or without glucose (as the carbohydrate) additions, compared with the ambient treatments that received no nutrient additions. The treatment that added both glucose and $\mathrm{NO}_{3}$ resulted in a variety of denitrification responses when compared with the addition of $\mathrm{NO}_{3}$ alone. In most cases, the addition of glucose to a given rate of $\mathrm{NO}_{3}$ addition resulted in higher rates of denitrification. These variable responses indicate that the amount of labile carbohydrates can limit denitrification even if $\mathrm{NO}_{3}$ is present. For most sites in both watersheds, the maximum denitrification rates ranged from 150 to 900 micromoles of nitrous oxide per square meter per hour. These rates were equivalent to the release of 37 to 221 grams of nitrogen per square meter per year. Weak positive correlations were observed between denitrification rate and soil temperature and measured ammonium concentration in groundwater. Weak negative correlations were observed between denitrification rate and water level and specific conductance.

The rates of denitrification in Bass Harbor Marsh and Northeast Creek under ambient conditions, both of which were relatively low, indicate that $\mathrm{NO}_{3}$ availability is low in both systems. It is evident from the addition of combined treatments of $\mathrm{NO}_{3}$ and glucose that these marsh soils are capable of comparatively high rates of denitrification, therefore, estuarine eutrophication is not a result of nitrogen inputs to marsh soils that are in excess of the denitrification capacity in these systems. If terrestrial inputs to the estuary are the cause of the observed eutrophic condition in Bass Harbor Marsh, then these inputs to the estuary must bypass the marsh in channelized surface flow, or perhaps they circumvent the marsh in shallow groundwater seepage along subsurface pathways that enter the estuary directly.

\section{Introduction}

Acadia National Park was created to protect the natural beauty of the only rocky headlands along the Atlantic coast of the United States. Fundamental to this purpose is protection of the ecological, scientific, and scenic attributes of the Acadia coastal ecosystems. More than 10 percent of the park's land area is classified as wetland (Calhoun and others, 1994), including forested and scrub/shrub wetlands, freshwater emergent marshes, peatlands, and salt marshes (Roman and others, 2001). The estuaries at the park provide unique habitats for fish and wildlife, nursery grounds for coastal fish species, and foraging habitat for wetland and aquatic birds. Estuaries also act as filters for water that ultimately enters the nearshore zone, thus helping to maintain the quality of coastal water (Herbert, 1999). Coastal salt marshes and wetlands are among the most productive ecosystems in North America, the tidally exported productivity of their wetland plant communities 
being capable of profoundly effecting estuarine productivity. Additionally, coastal wetlands are among the most threatened ecosystems in North America. Changes in the physiochemical conditions of sediment that are related to nutrient enrichment or perturbations because of human activity can alter the pattern of plant zonation, enabling highly competitive invasive plant species to potentially displace native plant species (Burke and others, 2002). Shoreline development and agricultural runoff also threaten the sustainability of salt marsh ecosystems throughout the northeastern United States (Silliman and Bertness, 2004; Fitch and others, 2009).

The Water Resources Management Plan for the Acadia National Park (Kahl and others, 2000) identifies accelerated rates of freshwater and of coastal marine eutrophication as a priority issue for water quality and as one of the most important challenges for resource management in the Park. Residential development outside the park boundary is increasing at an unprecedented rate. For example, between 1981 and 2001 the number of residences in the combined drainage basins of Aunt Betseys Creek, French Hill Brook, Old Mill Brook, and Stony Brook in the Northeast Creek (NEC) watershed increased from 83 to 279 (Nielsen, 2002a,b). Recent studies show that Bass Harbor Marsh (BHM) estuary is already tending toward a eutrophic state (Doering and others, 1995; Kinney and Roman, 1998). Evidence from many other Atlantic coast estuarine systems indicates that land clearing and subsequent installation of septic systems and application of lawn fertilizers are likely to increase nutrient loads of both groundwater and surface water entering the estuary (Harvey and Odum, 1990; Valiela and others, 1990, 2000; Howes and others, 1996; Bricker and others, 1999; National Research Council, 2000; Cloern, 2001; Tobias and others, 2001; Valiela and Bowen, 2002).

The chief nutrient of concern for eutrophication in the Acadia estuaries is nitrogen. Nitrogen inputs to the NEC and BHM watersheds and estuaries derive from atmospheric deposition, septic effluent, tidal inputs, agricultural runoff, and wildlife. Net mineralization of soil organic nitrogen also can contribute dissolved inorganic nitrogen species. Previous studies have quantified inputs from atmospheric deposition and from surface water for NEC (Nielsen, 2002a) and BHM (Doering and others, 1995), but inputs from groundwater and tidal sources have not been determined.

Previous studies at Acadia National Park have assumed that microbial denitrification removed a certain fraction of the nitrogen input to the watershed, but rates of denitrification (natural or maximum potential) in marsh soils have not been determined. Denitrification is the reduction of the aqueous nitrogen $(\mathrm{N})$ oxides, nitrate $\left(\mathrm{NO}_{3}^{-}\right)$and nitrite $\left(\mathrm{NO}_{2}{ }^{-}\right)$, to the gases nitric oxide $(\mathrm{NO})$, nitrous oxide $\left(\mathrm{N}_{2} \mathrm{O}\right)$, and dinitrogen $\left(\mathrm{N}_{2}\right)$ (Knowles, 1982). The generalized denitrification reactions are shown in the equations below.

Oxic reactions:

$$
\text { Organic } \mathrm{N} \stackrel{1}{\rightarrow} \mathrm{NH}_{4(\mathrm{aq})}^{+} \stackrel{2}{\rightarrow} \mathrm{NO}_{2(\mathrm{aq})}^{-} \stackrel{3}{\rightarrow} \mathrm{NO}_{3(\mathrm{aq})}^{-}
$$

Anoxic reactions:

$$
\mathrm{NO}_{3(\mathrm{aq})}^{-} \stackrel{4}{\rightarrow} \mathrm{NO}_{(\mathrm{g})} \stackrel{5}{\rightarrow} \mathrm{N}_{2} \mathrm{O}_{(\mathrm{g})} \stackrel{6}{\rightarrow} \mathrm{N}_{2(\mathrm{~g})}
$$

In this reaction pathway, in the oxic zone of marsh soils, organically bond nitrogen (organic $\mathrm{N}$ ) is shown being converted into inorganic aqueous ammonium $\left(\mathrm{NH}_{4}^{+}\right.$; reaction 1) that is heterotrophic decomposition of organic matter termed ammonification. In reaction $2\left(\mathrm{NH}_{4}^{+}\right)$is converted to $\mathrm{NO}_{2}^{-}$(aq) and in reaction $3 \mathrm{NO}_{2(\text { aq) }}^{-}$, is converted to $\mathrm{NO}_{3 \text { (aq) }}^{-}$these two reactions are collectively termed nitrification. When $\mathrm{NO}_{3 \text { (aq) }}^{-}$ enters the anoxic zone in marsh soils the sequence of denitrification reactions (reactions 4,5 , and 6) occur to produce $\mathrm{NO}_{(\mathrm{g})}$, $\mathrm{N}_{2} \mathrm{O}_{(\mathrm{g})}$, and $\mathrm{N}_{2(\mathrm{~g})}$.

In the course of these microbially mediated reactions both $\mathrm{N}_{2} \mathrm{O}$ and $\mathrm{N}_{2}$ may be released to the atmosphere, although $\mathrm{N}_{2}$ is typically the primary product. In wetland soils, such as the marshes at Acadia National Park, the amount of NO produced is usually very low compared to the amount of $\mathrm{N}_{2}$ and $\mathrm{N}_{2} \mathrm{O}$ because virtually all $\mathrm{NO}$ is converted to $\mathrm{N}_{2} \mathrm{O}$ before it can escape from soils (Davidson and Kingerlee, 1997). The final reaction in the denitrification reaction sequence (reaction 6) is the conversion of $\mathrm{N}_{2} \mathrm{O}$ to $\mathrm{N}_{2}$, this reaction is also termed consumption of $\mathrm{N}_{2} \mathrm{O}$. Under certain conditions, and during a defined time period, where the consumption of $\mathrm{N}_{2} \mathrm{O}$ is greater than the production of $\mathrm{N}_{2} \mathrm{O}$, then net consumption will be observed. Under natural conditions some variable fraction of the $\mathrm{N}_{2} \mathrm{O}$ that is produced is released to the atmosphere as a gas and the remainder is further reduced to dinitrogen gas $\left(\mathrm{N}_{2}\right)$ which is also released to the atmosphere (Knowles, 1982; Groffman and others, 2006). Acetylene blocks reaction 6, the conversion of $\mathrm{N}_{2} \mathrm{O}$ to $\mathrm{N}_{2}$ with the result that virtually all of the product of denitrification will be $\mathrm{N}_{2} \mathrm{O}$ (Tiedje and others, 1989; Groffman and others, 2006). Most denitrifying bacteria in soils are heterotrophs that oxidize organic matter and use inorganic nitrogen oxides as electron acceptors.

Denitrification occurs most readily when oxygen is depleted, that is, in suboxic conditions of less than 0.2 milligrams of oxygen per liter $\left(<0.2 \mathrm{mg} \mathrm{O}_{2} \mathrm{~L}^{-1}\right)$ that usually exist in a relatively thin stratum at the oxic/anoxic interface in wetland soils (Seitzinger and others, 2006). A variable water table and the presence of marsh vegetation, the roots of which can channel oxygen to deeper soil strata, can increase the availability of nitrate and suitable organic substrates for denitrifying bacteria. In the absence of oxygen, the tendency for increasingly negative reduction-oxidation potential favors other electron acceptors and inhibits the mineralization of organic nitrogen to $\mathrm{NO}_{3}$, thus restricting the zone of denitrification to the oxic/anoxic interface. In the NEC and BHM watersheds, we assume that most denitrification occurs in the marsh soils and in estuarine sediments, as Seitzinger and Nixon (1985), Seitzinger (1988), and Day and others (1989) have observed in other coastal wetlands.

Denitrification rates increase with increasing nitrogen loading (Seitzinger and others, 1984; Seitzinger and Kroeze, 1998; Wigand and others, 2004), and such rates have been 
shown to be seasonally and diurnally dependent, governed principally by temperature, supply of $\mathrm{NO}_{3}$, and availability of dissolved organic carbon (Smith and others, 1985; Jorgensen and Sorenson, 1988; Koch and others, 1992; Lee and others, 1997; Tobias and others, 2001). Other environmental factorssuch as the organic carbon content in sediment (Puckett and others, 2002), salinity, dissolved oxygen concentration (Koch and others, 1992), and hydrogen sulfide concentration (Sorenson and others, 1980) - also affect denitrification potential. Denitrification rates also are related to tidal flooding regime (Koch and others, 1992), pH, and sediment reduction-oxidation (redox) potential (Patrick and Delaune, 1977; Knowles, 1982; Smith and others, 1983). Because many factors influence denitrification rates and because reported rates are highly variable (for example, Greene, 2005; Seitzinger and others, 2006), it is important to determine ambient rates and maximum potential rates in areas of interest.

\section{Description of Study Area}

Northeast Creek (NEC) is a small microtidal estuary in the northeastern part of Mount Desert Island, Maine, that is experiencing increasing residential development in the watershed (fig. 1). The NEC watershed, 26.02 square kilometers $\left(\mathrm{km}^{2}\right)$ in areal extent, comprises several subwatersheds (fig. 2). A partial flow restriction near the estuary outlet results in tidal inundation of most marsh sediments only during high spring tides. Recent studies indicate that deep groundwater in the underlying fractured bedrock is not substantial in the freshwater budget for NEC (Nielsen, 2002b). Shallow groundwater in the NEC watershed is known to contain elevated levels of inorganic nitrogen, but the pathways by which this groundwater reaches the estuary are not known. We have assumed that some fraction of this shallow groundwater interacts with marsh soils before reaching the estuary and that some of the entrained inorganic nitrogen is denitrified in these soils. Shallow groundwater discharge is a potential mechanism for eutrophication, because it can deliver dissolved nitrogen species from domestic septic systems and from farming or other uses of fertilizer to estuaries (Valiela and others, 1990; Reay and others, 1992; Portnoy and others, 1998; Valiela and Bowen, 2002). Shallow groundwater can enter the marsh, and eventually the estuary, through seepage zones at the upland/wetland boundary, or groundwater can enter the estuary directly through the bottom and banks of creeks (Howes and others, 1996; Portnoy and others, 1998). Culbertson and others (2007) identified groundwater seeps in NEC and BHM by using aerial thermal imagery and continuous and discrete measurements of temperature and specific conductance in selected seeps, but the relative contribution of seeps to total inputs is unknown. Information is also lacking on current rates of denitrification, and, most importantly on whether these soils have the capacity to denitrify increasing rates of nitrogen addition that would very likely accompany increasing residential development.

Denitrification measurement sites in the NEC watershed were located in the marsh between the base of the hillslope and the estuary (fig. 3). Based on the classifications in a recent vegetation map (Lubinski and others, 2003) graminoid mix (Calamagrostis canadensis-Scirpus spp.-Dulichium arundinaceum) dominated the vegetation at sites GW1, GW3, and GW5; cranberry, sweet gale, leatherleaf, sphagnum shrub fen transitioning to willow scrub/shrub fen dominated the vegetation at site GW2; cattail marsh dominated the vegetation at site GW4; and sweet gale graminoid fen dominated the vegetation at site GW6. The soils were peat-dominated histosols, and the depth of the peat varied from about 1 meter $(\mathrm{m})$ near the base of the hillslopes to greater than $2 \mathrm{~m}$ near the estuary. During most of the field denitrification measurements the water table was at the land surface or less than 5 to 10 centimeters $(\mathrm{cm})$ below land surface. Although these sites did not flood tidally, they were flooded with freshwater for most of the period during June through November 2009 due to unusually high rainfall events and very slow drainage. The specific conductance in the shallow groundwater typically ranged from 400 to 3,000 microsiemens $(\mu \mathrm{S})$ (Huntington and others, 2011).

The BHM watershed, draining $21.78 \mathrm{~km}^{2}$, in the southwestern part of Mount Desert Island, comprises several subwatersheds (fig. 4), the largest of which, Marshall Brook, lies outside park boundaries and is substantially affected by residential and commercial development and a former landfill. Signs of eutrophication in BHM estuary, the largest tidal marsh estuary on the island, were documented more than 20 years ago (Doering and others 1995). Evidence of a continuing eutrophication in BHM in response to input of internal and external sources of nitrogen is noted in more recent studies (Kinney and Roman, 1998; Farris and Oviatt, 1999). A 1999 to 2000 study (Nielsen and others, 2002) corroborated the findings of Doering and others (1995) that dissolved inorganic nitrogen from freshwater sources comprises a substantial part of the total nitrogen load to BHM from Marshall and Heath Brooks; organic nitrogen comprised most of the total nitrogen from other tributaries feeding the BHM estuary (Doering and others, 1995).

Denitrification measurement sites in the BHM watershed were located in the marsh between the base of the hillslope and the estuary (fig. 5). Based on the classifications in a recent vegetation map (Lubinski and others, 2003) the vegetation at these sites was dominated by saltmeadow cordgrass and mixed gramioid forb saltmarsh. The vegetation adjacent to the estuary (where sites GW4 and GW6 were located) was much more dense compared with the sparse vegetation at the other sites. The soils were peat-dominated histosols, and the peat was of variable depth from about $1 \mathrm{~m}$ near the base of the hillslopes to greater than $2 \mathrm{~m}$ near the estuary. During most of the field denitrification measurements, the water table was at the land surface or less than $5 \mathrm{~cm}$ below land surface. These sites flooded tidally during high tide during most of the lunar tidal cycle. Our field measurements were conducted during the neap tides when the marsh surface did not flood. The specific conductance in the shallow groundwater typically ranged from 10,000 to $30,000 \mu \mathrm{S}$ (Huntington and others, 2011). 




Base from U.S. Geological Survey digital line graph, 1:100,000 Modified from Culbertson and others, 2007 Bar Harbor, 1985

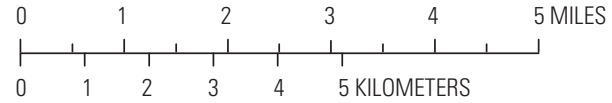

Figure 1. The locations of the study areas, including the Northeast Creek (NEC) and Bass Harbor Marsh (BHM) watersheds on Mount Desert Island, Maine. 


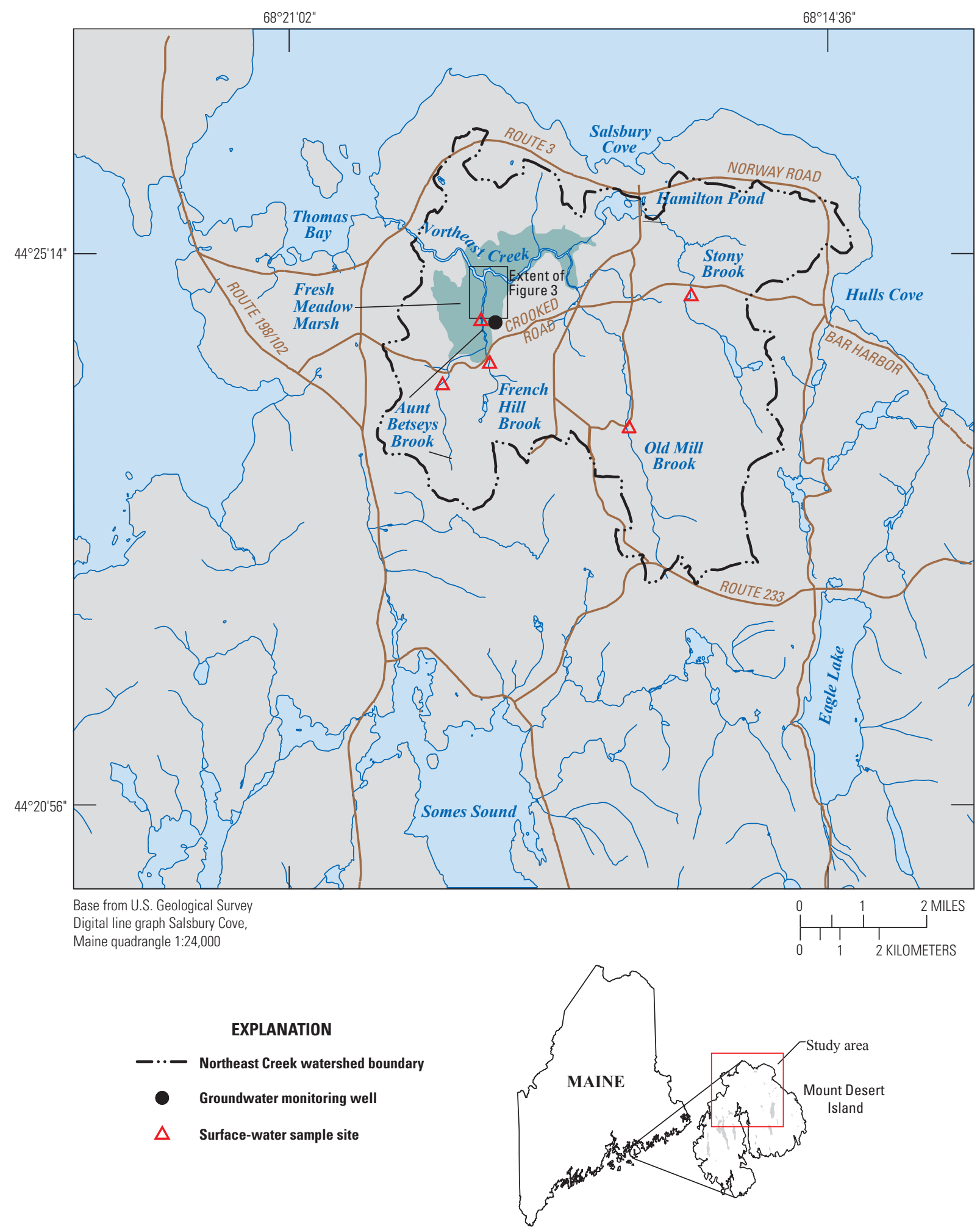

Figure 2. Northeast Creek watershed area, Mount Desert Island, Maine, and surface-water sampling locations on the major tributaries and the location of a groundwater monitoring well. 


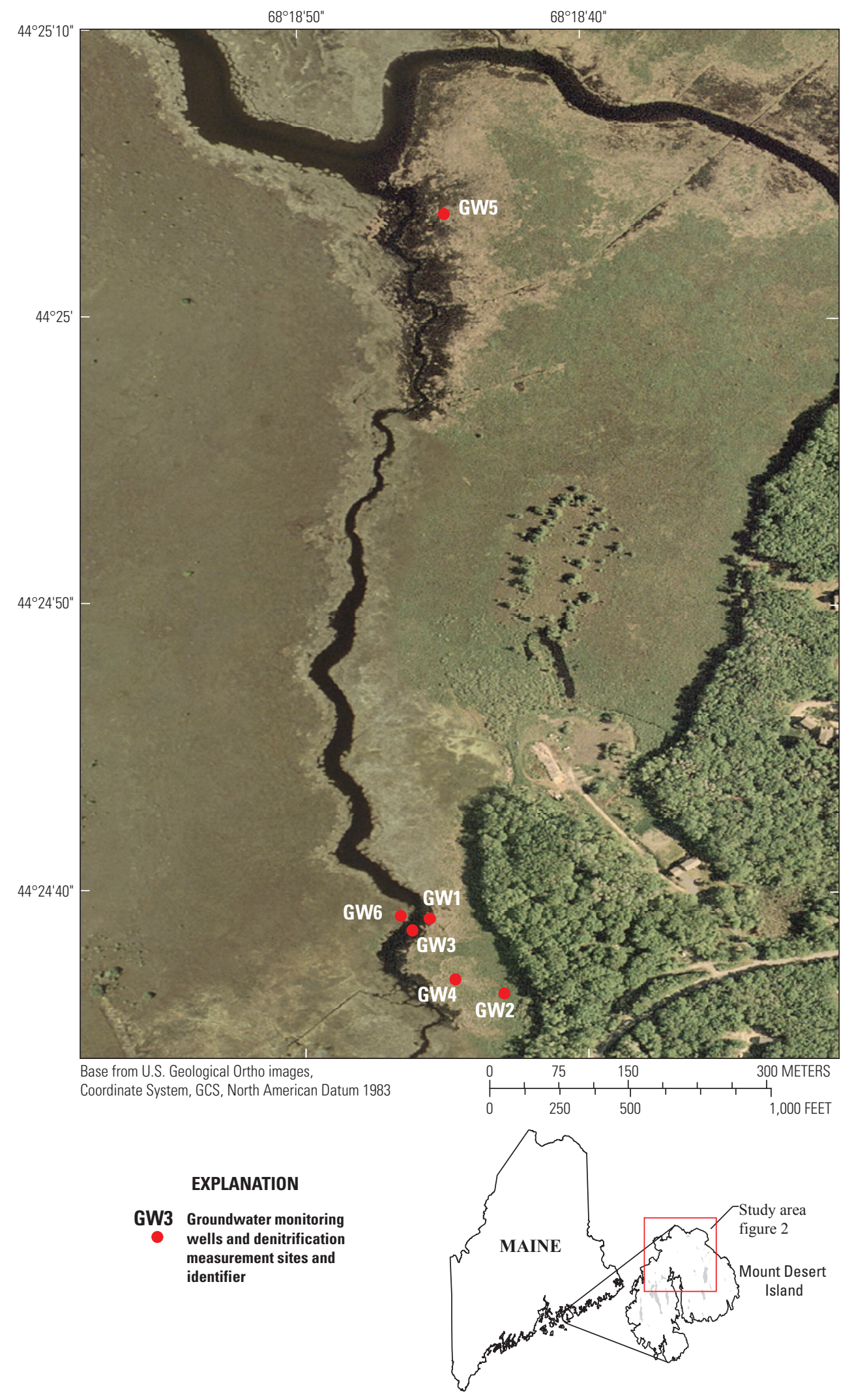

Figure 3. The locations of denitrification measurement sites and groundwater sampling wells in Northeast Creek watershed, Mount Desert Island, Maine. 


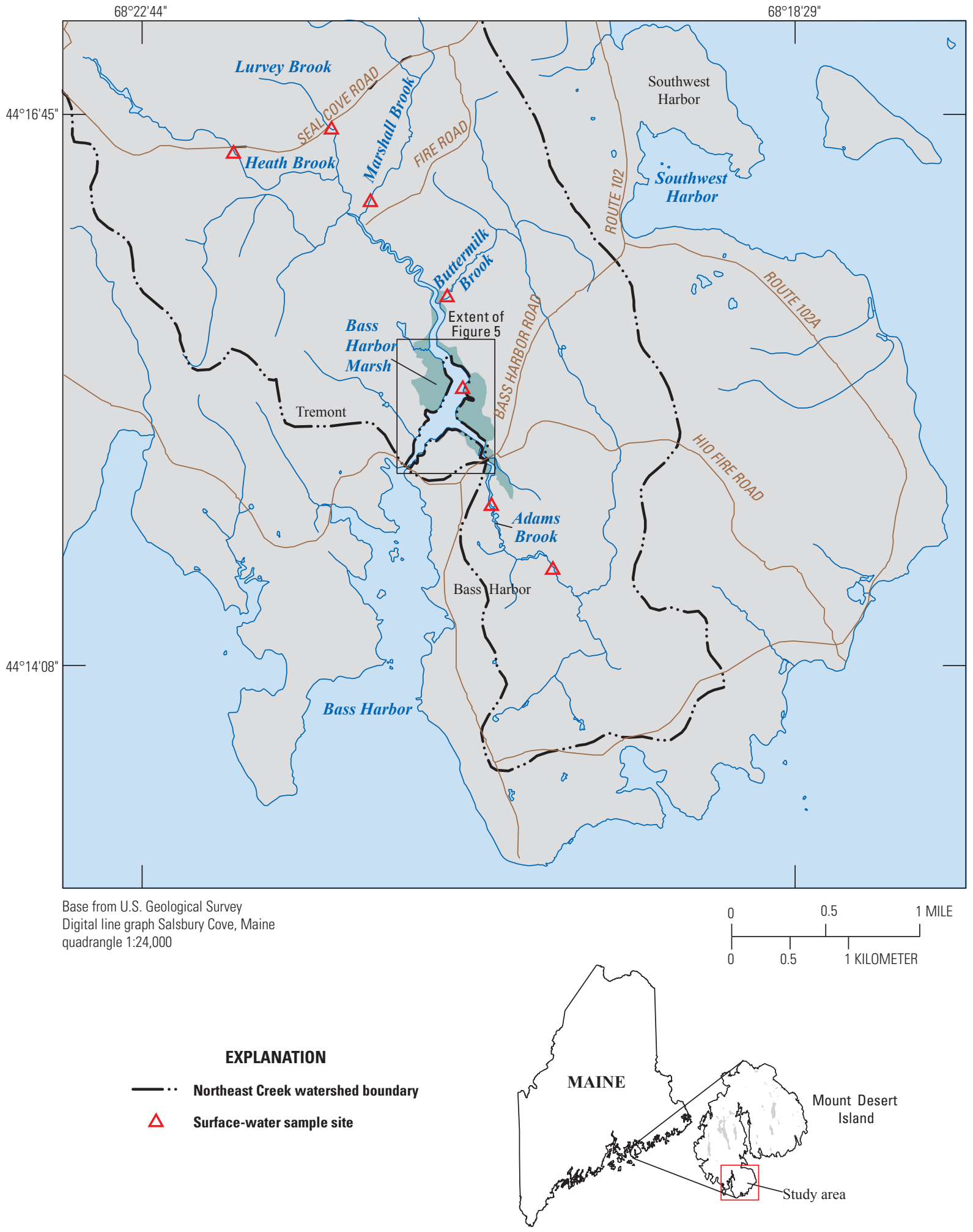

Figure 4. The location of Bass Harbor Marsh watershed, Mount Desert Island, Maine, and surface-water sampling locations on the major tributaries. 


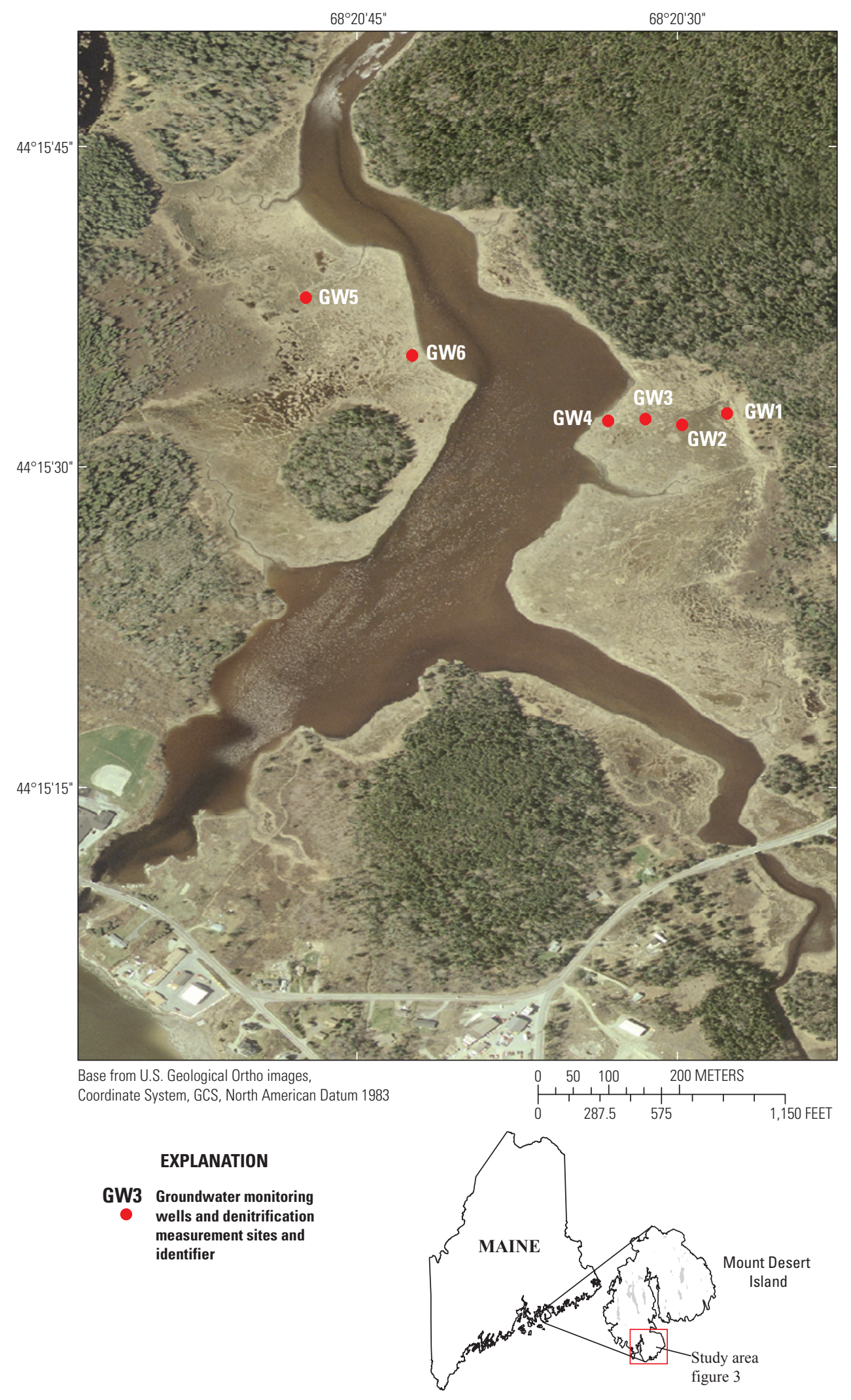

Figure 5. The locations of denitrification measurement sites and groundwater sampling wells in Bass Harbor Marsh watershed, Mount Desert Island, Maine. 


\section{Purpose and Scope}

This report provides estimates of in-place (in situ) rates of denitrification in marsh soils under ambient conditions and after treatment with $\mathrm{NO}_{3}$ alone, glucose alone, and combinations of $\mathrm{NO}_{3}$ and glucose in Northeast Creek and Bass Harbor Marsh watersheds, Mount Desert Island during the summers of 2008 and 2009. The data were collected by the U.S. Geological Survey (USGS), in cooperation with Acadia National Park, as part of a study to determine current in-place and maximum potential denitrification rates. Laboratory incubation experiments also are described that report the ratio of $\mathrm{N}_{2}$ to $\mathrm{N}_{2} \mathrm{O}$ produced during denitrification under ambient conditions (no treatment additions) and under treatments in which various rates of $\mathrm{NO}_{3}$ were added, with or without glucose, and with or without acetylene. The purpose of determining ratios of $\mathrm{N}_{2}$ to $\mathrm{N}_{2} \mathrm{O}$ produced in these laboratory experiments was to apply these ratios in field measurements during which no acetylene block was used and in which only $\mathrm{N}_{2} \mathrm{O}$ was measured. Ratios from the laboratory experiments also informed the design of the field experimental additions of $\mathrm{NO}_{3}$ and glucose additions to assure that appropriate rates of these additions would be applied. The more controlled conditions of the laboratory experiments, in conjunction with the field experiments assisted in the study's understanding of denitrification responses to treatments that included glucose only, acetylene only, and various rates of nitrogen additions with and without glucose.

Ancillary measurements that were made during this study are reported to help explain variations in measured denitrification rates. Nutrient data in surface water and groundwater and specific conductance, temperature, and dissolved oxygen data are included in this report. Surface water chemistry of the tributaries draining to these estuaries is discussed in relation to previously published measurements for these sites. This report evaluates whether the entire record of surface water chemistry support detectable temporal trends in various nutrient concentrations. This report also provides data on groundwater level that was recorded continuously during the growing season in Fresh Meadow Marsh in the NEC watershed. Finally, this report also provides data on soil temperature, precipitation, and discharge at Otter Creek, on air temperature, and on tides. Additional details on methods and quality assurance to ensure data quality are reported in Huntington and others (2011).

\section{Field Denitrification Methods}

In-place denitrification measurements were made by using a static chamber technique in which denitrification was estimated from the increase in $\mathrm{N}_{2} \mathrm{O}$ concentration in the headspace of a chamber placed on the surface of the marsh sediment (Oremland and others, 1984; Meding and others, 2001). The flux chambers were constructed from white opaque plastic buckets having an internal diameter of $28.4 \mathrm{~cm}$ and were equipped with battery-operated fans to mix the gas in the headspace and with rubber septa for sampling the gas.
The chambers were pressed into the soil surface to a depth of $10 \mathrm{~cm}$, thus insuring an effective seal so that the $\mathrm{N}_{2} \mathrm{O}$ released from the soil into the headspace could not escape or be mixed with ambient air. The volume of the headspace was recorded during each incubation. Gas samples for $\mathrm{N}_{2} \mathrm{O}$ analysis were collected from the chambers through rubber septa using glass syringes at various time intervals following installation and sealing of the chambers. Gas samples were stored in glass vacutainers (vials) sealed with Teflon-lined butyl rubber stoppers. Huntington and others (1998) describe the static chamber technique for measuring soil respiration.

Denitrification measurements (based on measured $\mathrm{N}_{2} \mathrm{O}$ release rates) were made in marsh soils in NEC and BHM. Table 1 lists the dates and sites of the flux measurements, whether the measurements were made under ambient conditions, or whether $\mathrm{NO}_{3}$ was added and at what rate or whether glucose, or both were added. Nitrate, glucose, and acetylene (in a limited number of experiments) additions were made after the chambers had been installed into the soil to ensure that the additions were confined to the soil beneath the chambers. Treatment solutions of $\mathrm{NO}_{3}$ and glucose were made from concentrates prepared in the laboratory and diluted in the field with shallow groundwater that was pumped from piezometers at the denitrification measurement sites. One liter (L) of a solution of the indicated concentration of $\mathrm{NO}_{3}$ or $\mathrm{NO}_{3}$ and glucose was added through an opening in the top of the chamber by using a funnel. These additions of 0 , $5,15,25,50,75,100,200,250,500$, and 1,000 millimolar (mM) $\mathrm{NO}_{3}$ solutions were equivalent to nitrogen addition rates of $0,1.1,3.3,5.5,11,17,22,44,55,110$, and 221 grams of nitrogen per square meter $\left(\mathrm{g} \mathrm{N} \mathrm{m}^{-2}\right)$ respectively. This report refers to "ambient" treatments as those receiving zero $\mathrm{NO}_{3}$ and zero glucose. For treatments in which glucose was added, the 1-L treatment solutions contained $75 \mathrm{mM}$ glucose, equivalent to $213 \mathrm{~g}$ glucose $\mathrm{m}^{-2}$ when the glucose was applied to each chamber. After the treatment additions, a rubber septum was installed in the top of each chamber to ensure a gas-tight seal, and the fans were started in order to mix the gases in the chamber headspace. In most cases, two or three replicate chambers were used in order to determine average denitrification rates at a given location and for a given treatment. One exception was treatments in which both $\mathrm{NO}_{3}$ and glucose were added; in these cases, one chamber usually received this treatment at a given site.

Preliminary measurements indicated that little to no $\mathrm{N}_{2} \mathrm{O}$ was released under ambient conditions. If denitrification were occurring under ambient conditions in the field, it was possible that virtually all of the $\mathrm{N}_{2} \mathrm{O}$ was being converted to $\mathrm{N}_{2}$. To rule out this possibility in a limited number of initial field experiments we used acetylene inhibition, which prevents $\mathrm{N}_{2} \mathrm{O}$ from being converted to $\mathrm{N}_{2}$ so that we would detect denitrification if it were occurring under ambient conditions. Acetylene was added in the field, following the method described by Tiedje and others (1989) by bubbling acetylene gently into the 1-L solutions for 2 minutes to saturate the solutions before introducing these saturated solutions into the chambers. 
Table 1. Dates of field (in situ) denitrification rate measurements, locations of measurements, and treatments applied on measurement dates.

[ $\mathrm{g} \mathrm{N} \mathrm{m}^{-2}$, grams of nitrogen per square meter; NEC, Northeast Creek watershed; GW, groundwater site; FC, flux chamber; BHM, Bass Harbor Marsh watershed. $\mathrm{An}$ " $\mathrm{X}$ " indicates that the treatment was included in the experiment on that date. A " $\mathrm{Y}$ " indicates that measurements on this date included the addition of acetylene. A "Z" indicates that measurements on this date included the addition of nitrate plus glucose; --, additive was not included in measurements on this date]

\begin{tabular}{|c|c|c|c|c|c|c|c|}
\hline Date & $\begin{array}{c}\text { Start } \\
\text { month/day }\end{array}$ & Site name(s) & Ambient & $\begin{array}{l}\text { Nitrate } 1 \\
\left(\mathrm{~g} \mathrm{~N} \mathrm{~m}^{-2}\right)\end{array}$ & Acetylene & $\begin{array}{c}\text { Glucose }^{1} \\
\left.\text { (g glucose } \mathrm{m}^{-2}\right)\end{array}$ & $\begin{array}{l}\text { Nitrate plus } \\
\text { glucose }\end{array}$ \\
\hline \multirow[t]{2}{*}{ May 2008} & $5 / 29$ & NEC GW1-2 & $\mathrm{X}$ & -- & -- & -- & -- \\
\hline & $5 / 30$ & NEC GW3-4 & $\mathrm{X}$ & -- & -- & -- & -- \\
\hline \multirow[t]{3}{*}{ June 2008} & $6 / 10$ & NEC GW1-3 & $\mathrm{X}$ & -- & Y & -- & -- \\
\hline & $6 / 11$ & NEC GW4,6 & $\mathrm{X}$ & -- & -- & -- & -- \\
\hline & $6 / 12$ & NEC GW5 & $\mathrm{X}$ & -- & -- & -- & -- \\
\hline \multirow[t]{10}{*}{ July 2008} & $7 / 15$ & NEC GW1, GW3 & $\mathrm{X}$ & -- & -- & -- & -- \\
\hline & $7 / 16$ & NEC GW1, GW3 & -- & 1.1 & -- & -- & -- \\
\hline & $7 / 16$ & NEC GW4 & $\mathrm{X}$ & -- & -- & -- & -- \\
\hline & $7 / 17$ & NEC GW2 FC1-3 & $\mathrm{X}$ & -- & -- & -- & -- \\
\hline & $7 / 17$ & NEC GW2 FC4-6 & $\mathrm{X}$ & 1.1 & -- & -- & -- \\
\hline & $7 / 17$ & NEC GW4 FC4-6 & -- & 1.1 & -- & -- & -- \\
\hline & $7 / 17$ & NEC GW5 FC1-3 & $\mathrm{X}$ & -- & -- & -- & -- \\
\hline & $7 / 17$ & NEC GW5 FC5-6 & -- & 1.1 & -- & -- & -- \\
\hline & $7 / 18$ & NEC GW6 FC1-4 & $\mathrm{X}$ & -- & -- & -- & -- \\
\hline & $7 / 18$ & NEC GW6 FC5-6 & -- & 1.1 & -- & -- & -- \\
\hline \multirow[t]{2}{*}{ Aug. 2008} & $8 / 13$ & NEC GW4, GW2 & $\mathrm{X}$ & 1.1 & Y & -- & -- \\
\hline & $8 / 14$ & NEC GW4 & -- & 11 & $\mathrm{Y}$ & -- & -- \\
\hline \multirow[t]{6}{*}{ Sept. 2008} & $9 / 10$ & BHM GW3 & $\mathrm{X}$ & -- & -- & -- & -- \\
\hline & $9 / 11$ & BHM GW3 & -- & $5.5,11 ; 16.5 ; 22$ & -- & -- & -- \\
\hline & $9 / 12$ & BHM GW3, GW2 & -- & 5.5 & $\mathrm{Y}$ & -- & -- \\
\hline & $9 / 15$ & BHM GW1 & -- & 5.5 & $\mathrm{Y}$ & -- & -- \\
\hline & $9 / 15$ & BHM GW4 & -- & 5.5 & $\mathrm{Y}$ & -- & -- \\
\hline & $9 / 16$ & BHM GW5 & -- & 3.3 & -- & -- & -- \\
\hline Oct. 2008 & $10 / 30$ & BHM GW6 & -- & $22 ; 55 ; 110 ; 220$ & $\mathrm{Y}$ & -- & -- \\
\hline \multirow[t]{3}{*}{ June 2009} & $6 / 15$ & BHM GW1-6 & $\mathrm{X}$ & -- & -- & -- & -- \\
\hline & $6 / 16$ & BHM GW3 & -- & $1.1 ; 5.5 ; 11 ; 22 ; 55 ; 110$ & -- & 213 & Z \\
\hline & $6 / 17$ & BHM GW2 & -- & $1.1 ; 5.5 ; 11 ; 22 ; 55 ; 110$ & -- & 213 & Z \\
\hline \multirow[t]{4}{*}{ July 2009} & $7 / 13$ & BHM GW1-6 & $\mathrm{X}$ & -- & -- & -- & -- \\
\hline & $7 / 14$ & BHM GW4 & -- & $1.1 ; 5.5 ; 11 ; 22 ; 55 ; 110$ & -- & 213 & Z \\
\hline & $7 / 15$ & BHM GW6 & -- & $1.1 ; 5.5 ; 11 ; 22 ; 55 ; 110$ & -- & 213 & Z \\
\hline & $7 / 16$ & NEC GW1-6 & $\mathrm{X}$ & -- & -- & 213 & -- \\
\hline \multirow[t]{2}{*}{ Aug. 2009} & $8 / 25$ & BHM GW1-6 & $\mathrm{X}$ & -- & -- & 213 & -- \\
\hline & $8 / 26$ & BHM GW5 & $\mathrm{X}$ & $1.1 ; 5.5 ; 11 ; 22 ; 44$ & -- & 213 & Z \\
\hline \multirow[t]{2}{*}{ Sept. 2009} & $9 / 21$ & NEC GW1-6 & $\mathrm{X}$ & -- & -- & 213 & -- \\
\hline & $9 / 22$ & NEC GW4 & $\mathrm{X}$ & $1.1 ; 5.5 ; 11 ; 22 ; 44$ & -- & 213 & $\mathrm{Z}$ \\
\hline
\end{tabular}

${ }^{1}$ Nitrate and glucose were added in 1 liter of solution through the top of the chamber after sealing to the marsh surface immediately before sealing the chamber and thus initiating the incubation time. 
Repeated measurements were made during the growing seasons in 2008 and 2009 at six denitrification sites in NEC (fig. 3) and six in BHM (fig. 5). Flooding during both years limited the number of denitrification measurements that could be made in NEC. Standing water greater than $5 \mathrm{~cm}$ in altitude over the marsh soil surface prevented denitrification measurements with the type of chamber used.

\section{Laboratory Denitrification Methods}

During denitrification, $\mathrm{N}_{2}$ and $\mathrm{N}_{2} \mathrm{O}$ are produced, but $\mathrm{N}_{2}$ is usually the primary by product (Knowles, 1982). The ratio of $\mathrm{N}_{2}$ to $\mathrm{N}_{2} \mathrm{O}$ can vary, depending on landscape position (Meding and others, 2001), sediment properties, and availability of $\mathrm{NO}_{3}$ (Weier and others, 1993; Parton and others, 1996; Lee and others, 1997). To determine these site-specific ratios we conducted classic laboratory acetylene inhibition denitrification assays (Oremland and others, 1984; Duff and others, 1996) on sediment samples collected at each of the denitrification measurement sites. We did not expect differences in ratios based on moisture content because these soils were saturated at all times. We ran experiments to determine ratios under conditions of no $\mathrm{NO}_{3}$ addition and two levels of $\mathrm{NO}_{3}$ addition to account for potential differences in ratios that might depend on $\mathrm{NO}_{3}$ availability. We attempted to address the issue of differences in soil properties by determining ratios using soils from many different sites rather than applying a single ratio for all sites. We were not able to control for potential differences in ratios that might have resulted from differences in temperature between our laboratory experiments and the field. We estimated the ratio of $\mathrm{N}_{2}$ to $\mathrm{N}_{2} \mathrm{O}$ produced by comparing $\mathrm{N}_{2} \mathrm{O}$ produced in the absence of acetylene and in the presence of acetylene (Meding and others, 2001). Acetylene blocks the microbial conversion of $\mathrm{N}_{2} \mathrm{O}$ to $\mathrm{N}_{2}$ (Tiedje and others, 1989; Groffman and others, 2006), therefore in the presence of acetylene all of the gaseous nitrogen released will be in the form of $\mathrm{N}_{2} \mathrm{O}$. Denitrification rate was calculated by applying the appropriate ratio of $\mathrm{N}_{2}$ to $\mathrm{N}_{2} \mathrm{O}$ as follows:

Denitrification rate $=\left[\left(\mathrm{N}_{2} \mathrm{O}_{\mathrm{PR}}\right) \times\left(\mathrm{N}_{2}: \mathrm{N}_{2} \mathrm{O}\right)\right]+\left(\mathrm{N}_{2} \mathrm{O}_{\mathrm{PR}}\right)$

where

$\mathrm{N}_{2} \mathrm{O}_{\mathrm{PR}} \quad$ is $\mathrm{N}_{2} \mathrm{O}$ production rate, and

$\mathrm{N}_{2}: \mathrm{N}_{2} \mathrm{O}$ is the ratio of $\mathrm{N}_{2}$ produced to $\mathrm{N}_{2} \mathrm{O}$ produced.

All rates are reported in units of micromoles of $\mathrm{N}_{2} \mathrm{O}$ per square meter per hour.

There are important limitations to this approach to estimating in-place denitrification rates. Because of differences in temperature, sediment structure, and redox status, we do not know whether the laboratory determined $\mathrm{N}_{2}$ to $\mathrm{N}_{2} \mathrm{O}$ ratios are comparable to the true field ratios. To our knowledge, no methods can yet let us determine the "true" field $\mathrm{N}_{2}: \mathrm{N}_{2} \mathrm{O}$ ratios because all approaches that have been attempted are accompanied by serious limitations and simplifying assumptions (Groffman and others, 2006). Therefore we are not able to assess the error associated with this method. The main limitation to the acetylene inhibition approach is that acetylene can also inhibit nitrification (Groffman and others, 2006). This would be most problematic when the $\mathrm{NO}_{3}$ denitrified during the field measurement is derived mostly from nitrification taking place during that "incubation period" rather than being derived from ambient nitrogen within pore waters. The advantage of this in-place method is that the primary incubation is done in the field, thereby avoiding the compromising of variables that occurs when soils or sediments are brought to the laboratory and assayed under conditions very unlike those in the field. This method is particularly advantageous for this project's objective of determining maximum potential denitrification rates because, in conditions in which $\mathrm{NO}_{3}$ levels are high (as in our treatments that add $\mathrm{NO}_{3}$ ), the inhibitory effect of acetylene on nitrification is no longer a relevant issue.

Soils from all of the measurement sites were assayed to determine $\mathrm{N}_{2}$ to $\mathrm{N}_{2} \mathrm{O}$ ratios and in these experiments moderate amounts of $\mathrm{NO}_{3}$ were added to stimulate denitrification and to make the conditions comparable to in-place treatments where $\mathrm{NO}_{3}$ was added. Soils from half of the measurement sites were assayed to determine $\mathrm{N}_{2}$ to $\mathrm{N}_{2} \mathrm{O}$ ratios under ambient conditions (no treatment additions) and under conditions where $\mathrm{NO}_{3}$ and glucose were added together. Preliminary observations of $\mathrm{N}_{2} \mathrm{O}$ production rates in these laboratory experiments indicated that production rates were very low; indeed, $\mathrm{N}_{2} \mathrm{O}$ consumption was occasionally observed when $\mathrm{NO}_{3}$ was not added. It was therefore decided that using average ratios determined from two or three sites under ambient conditions would provide a reasonable estimate of the $\mathrm{N}_{2}$ to $\mathrm{N}_{2} \mathrm{O}$ ratios without performing these experiments on the soils from all locations. If we observed $\mathrm{N}_{2} \mathrm{O}$ consumption in individual replicates in these experiments, we did not use the $\mathrm{N}_{2}$ to $\mathrm{N}_{2} \mathrm{O}$ ratios from these replicates to determine average $\mathrm{N}_{2}$ to $\mathrm{N}_{2} \mathrm{O}$ ratios for use in the computation of rates of $\mathrm{N}_{2} \mathrm{O}$ production.

Marsh soil was collected using a hand auger to a depth of 1.25 meters $(\mathrm{m})$ and the material was stored at 4 degrees Celsius $\left({ }^{\circ} \mathrm{C}\right)$ until use. Groundwater was also obtained from shallow piezometers at NEC and at BHM for use in the laboratory incubations. This groundwater was also stored at $4{ }^{\circ} \mathrm{C}$ until use. Large root fragments were removed and the soil material was ground up using a hand-operated food grinder to facilitate mixing and to allow subsequent subsampling of representative fractions of the original sample. Approximately $20 \mathrm{~g}$ of fresh soil was weighed into each 135 cubic centimeter $\left(\mathrm{cm}^{3}\right)$ glass flask. The groundwater from each location was used to make up solutions containing various concentrations of $\mathrm{NO}_{3}$ on the same day that these treatments were used in the laboratory incubation experiments. Twenty milliliters $(\mathrm{mL})$ of each appropriate solution was added to each flask, and then the flasks were sealed. These $20-\mathrm{mL}$ solutions of 5, 10, 50, $75,100,200,500,750$ and $1,000 \mathrm{mM} \mathrm{NO}_{3}$ were equivalent to nitrogen addition rates of $0.01,0.14,0.7,1.05,1.4,3.5,7$, 
$10.5,14 \mathrm{mg} \mathrm{N} \mathrm{g}^{-1}$ fresh soil in the incubation flask respectively). Deionized water was used to make a stock solution of 1-molar (M) glucose. Syringes were used to add $0.4 \mathrm{~mL}$ of the $1-\mathrm{M}$ glucose solution to each flask that received the glucose treatment bringing the solution to a final glucose concentration of $19.6 \mathrm{mM}$ (equivalent to $3.6 \mathrm{mg}$ glucose per gram of fresh soil). The screw cap lids for the flasks were Teflon lined and were equipped with a rubber septum to facilitate additions of glucose by syringe, sparging with helium (He), addition of acetylene, or simply gas sampling using syringes.

After sealing, all flasks were sparged with ultrahigh purity (UHP) He for 20 minutes to establish anoxic conditions. For treatments that received acetylene, $14 \mathrm{~cm}^{3}$ of headspace was first removed by syringe and then $14 \mathrm{~cm}^{3}$ of acetylene was added to achieve a final headspace concentration of approximately 15 percent acetylene by volume. All flasks were then placed on a mechanical shaker for 5 minutes. After this initial equilibration, 4-mL gas samples were withdrawn from each flask and transferred to $3-\mathrm{mL}$ vacutainers to determine $\mathrm{N}_{2} \mathrm{O}$ concentration at time zero $\left(\mathrm{T}_{0}\right)$. Two gas bags were prepared: one contained UHP He, and the other contained 15 percent acetylene (by volume) in UHP He. Four mL of "make-up" gas from the appropriate bag was added to all flasks after collecting $\mathrm{T}_{0}$ samples to restore the original headspace volume and pressure. After adding the appropriate make-up gas for each treatment, the flasks were shaken continuously until the subsequent collection of gas samples (for example, $\mathrm{T}_{1}, \mathrm{~T}_{2}, \mathrm{~T}_{3}$, or $\mathrm{T}_{4}$ ). During each subsequent sampling, $4 \mathrm{~mL}$ of gas was collected from the headspace by syringe and transferred to a 3 -mL vacutainer, and $4 \mathrm{~mL}$ of make-up gas was added back to each flask. The gas samples in vacutainers were shipped to a laboratory for analysis.

Subsamples of fresh, ground, and homogenized marsh soils were analyzed to determine the water fraction and the fraction of organic matter $(\mathrm{OM})$. Fresh soil samples were weighed and then oven-dried at $105^{\circ} \mathrm{C}$ until they reached a constant weight; they were then reweighed to gravimetrically determine the water fraction (grams of water per gram of oven-dry soil). These samples were ashed in a muffle furnace at $500^{\circ} \mathrm{C}$ until they reached a constant weight, whereupon they were reweighed to gravimetrically determine the OM content (grams OM per gram oven-dry soil) (Davies, 1974). The results of the gravimetric analysis were used to present the denitrification data on a per dry weight or per organic matter weight basis.

\section{Laboratory $\mathrm{N}_{2} \mathrm{O}$ Analytical Methods and Computation of $\mathrm{N}_{2} \mathrm{O}$ Release Rate}

The gas samples were shipped to a USGS laboratory in Menlo Park, California, for determination of $\mathrm{N}_{2} \mathrm{O}$. Gas samples were analyzed by nickel-63 electron capture detection gas chromatography using standard methods (Oremland and others, 1984; Duff, 1996; Aelion and Shaw, 2000). This laboratory maintains quality assurance and quality control protocols that include duplicate analyses, blanks, and multiple calibration standards during all sample runs. The laboratory reported the $\mathrm{N}_{2} \mathrm{O}$ concentrations from the vacutainers (headspace at each sampling time) in units of nanomoles $\mathrm{N}_{2} \mathrm{O} \mathrm{mL}^{-1}$. In-place rates of $\mathrm{N}_{2} \mathrm{O}$ release were determined as nanomoles $\mathrm{N}_{2} \mathrm{O} \mathrm{m}^{-2} \mathrm{hr}^{-1}$ using the volume of the chamber headspace, the initial and subsequent headspace concentrations, the area of the marsh surface covered by the chamber $\left(\mathrm{m}^{-2}\right)$, and the duration of the incubation (hr):

$$
\mathrm{N}_{2} \mathrm{O} \text { release rate }=\frac{\frac{\mathrm{T}_{2} \text { Conc. } \times \text { vol. }}{\text { area }}+\mathrm{T}_{1} \text { Conc. } \times \text { vol. }}{\text { incubation time }},
$$

$$
\begin{aligned}
& \text { where } \\
& \mathrm{T}_{1 \text { Conc. } \times \text { vol. }}=\begin{array}{l}
\text { is concentration of } \mathrm{N}_{2} \mathrm{O} \text { multiplied by } \\
\text { the chamber volume at the start of the } \\
\text { incubation period, and }
\end{array} \\
& \mathrm{T}_{2 \text { Conc. } \times \text { vol. }}=\begin{array}{l}
\text { is concentration of } \mathrm{N}_{2} \mathrm{O} \text { multiplied by } \\
\text { the chamber volume at the end of the } \\
\text { incubation period. }
\end{array}
\end{aligned}
$$

\section{Field Methods for Water Quality Sampling and Measurements}

Samples were collected from tributaries that flow into the NEC and BHM estuaries (figs. 2, 4; table 2) on an approximately monthly schedule during the 2008 and 2009 growing seasons. Table 3 lists the constituents analyzed in these samples which were collected from shallow groundwater in NEC and BHM marsh soils at the sites where in-place denitrification measurements were made (figs. 3, 5). A field meter was used to determine specific conductance and temperature at these surface-water and groundwater sampling locations.

A peristaltic pump was used for sampling surface water pumping water directly from a fast-flowing section of the tributary through a cartridge filter $(0.45$-micrometer $(\mu \mathrm{m})$ polyether sulfone membrane filters), and into a $125-\mathrm{mL}$ amber polyethylene bottle at each measuring site. All groundwater samples were collected by pumping water from shallow piezometers that were installed in the NEC and BHM marsh soils at the measurement sites. The piezometers were 5-cmdiameter commercial PVC, 1 meter in length, and screened over the entire length, except within $15 \mathrm{~cm}$ of each end. The screen size was $0.0254 \mathrm{~cm}$, and the bottoms of the piezometers were equipped with a conical 5 -cm well point. Holes were augured with a hand auger by using a $3.75-\mathrm{cm}$ diameter bit to ensure a tight seal between the piezometers and the surrounding marsh soil. Piezometers were installed with unscreened pipe $10 \mathrm{~cm}$ in altitude above land surface, and with caps installed to prevent precipitation from entering. Samples were pumped with a peristaltic pump or a vacuum pump into 
Table 2. Surface water and groundwater water-quality monitoring stations in Northeast Creek and Bass Harbor Marsh watersheds sampled in 2008 and 2009.

[Latitude and longitude determined with Global Positioning System ( \pm 2 to 5 meters); USGS, U.S. Geological Survey; mi² , square miles; NEC, Northeast Creek watershed; BHM, Bass Harbor Marsh watershed; GW, groundwater site]

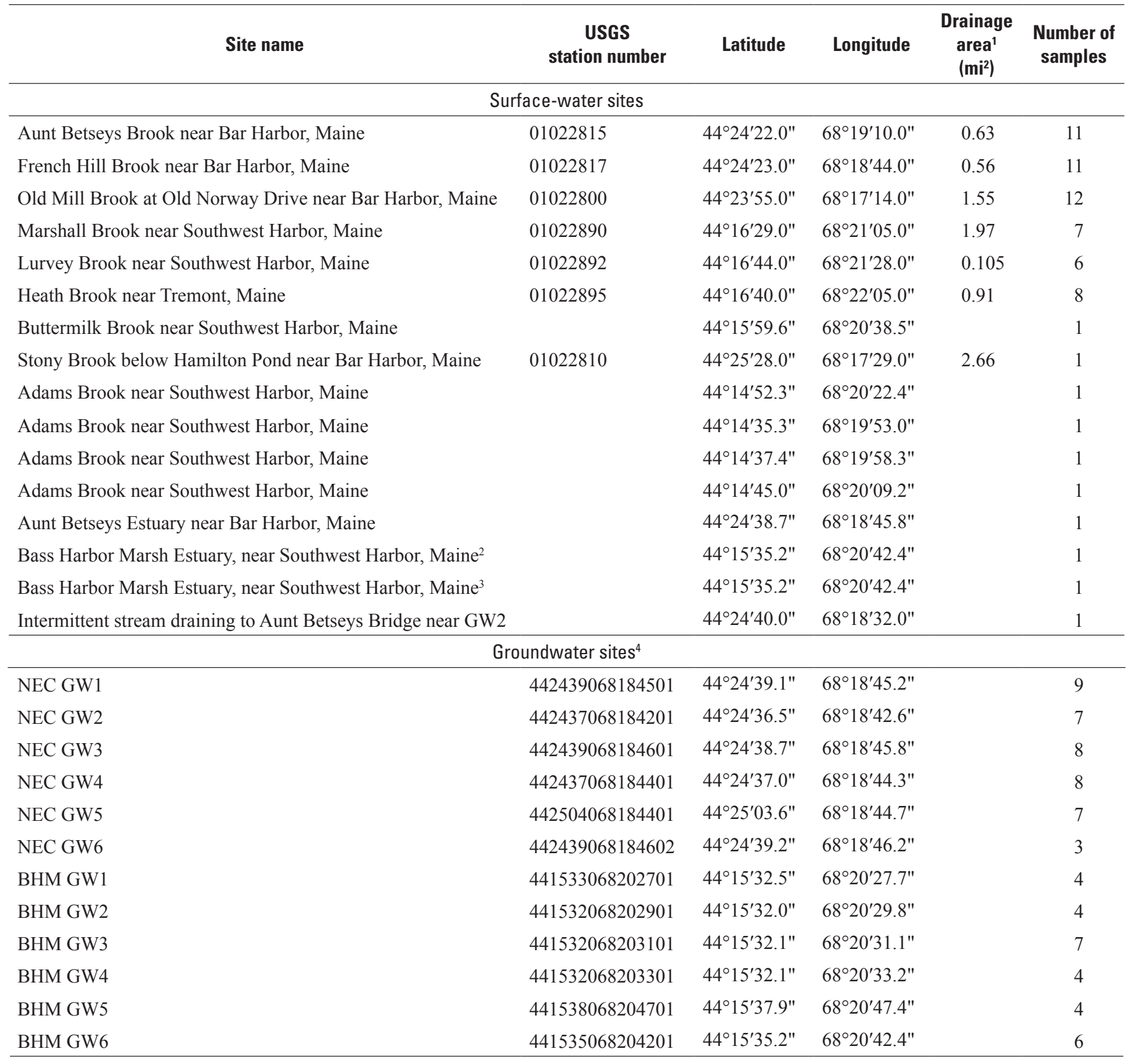

${ }^{1}$ Drainage areas not available for surface-water sites without USGS sites identification numbers.

${ }^{2}$ Sample collected at water surface.

${ }^{3}$ Sample collected 20 centimeters below water surface.

${ }^{4}$ For groundwater sites, only pretreatment (ambient) samples were collected. Drainage areas are not applicable to groundwater sites. 
Table 3. Constituent name, U.S. Geological Survey National Water Information System parameter codes and method codes, and minimum reporting limits for temperature, specific conductance, dissolved oxygen, and nutrients.

$\left[{ }^{\circ} \mathrm{C}\right.$, degrees Celsius; na, not applicable; $\mu \mathrm{S} / \mathrm{cm}$, microsiemens per centimeter; $\mathrm{mg} / \mathrm{L}$, milligrams per liter; $\mathrm{N}$, nitrogen; $\mathrm{P}$, phosphorus $]$

\begin{tabular}{lccc}
\hline \multirow{2}{*}{ Water-quality constituent } & \multicolumn{2}{c}{ USGS and NWIS codes } & \multirow{2}{*}{ Minimum or laboratory reporting limit } \\
\cline { 2 - 3 } & Parameter & Method & \\
\hline Temperature, water $\left({ }^{\circ} \mathrm{C}\right)$ & 00010 & na & $0.01{ }^{\circ} \mathrm{C}$ \\
Specific conductance, field $\left(\mu \mathrm{S} / \mathrm{cm}\right.$ at $\left.25^{\circ} \mathrm{C}\right)$ & 00094 & na & $1.0 \mu \mathrm{S} / \mathrm{cm}$ \\
Oxygen, dissolved $(\mathrm{mg} / \mathrm{L})$ & 00300 & na & $0.1 \mathrm{mg} / \mathrm{L}$ \\
Ammonium $(\mathrm{mg} / \mathrm{L}$ as N) & 00608 & 00623 & $0.01 \mathrm{mg} / \mathrm{L}$ \\
Silica, dissolved $\left(\mathrm{mg} / \mathrm{L}\right.$ as $\left.\mathrm{SiO}_{2}\right)$ & 00955 & $\mathrm{CL} 151$ & $0.5 \mathrm{mg} / \mathrm{L}$ \\
Phosphorus, orthophosphate, dissolved $(\mathrm{mg} / \mathrm{L}$ as P) & 00671 & 00048 & $0.006 \mathrm{mg} / \mathrm{L}$ \\
Nitrate plus nitrite $(\mathrm{mg} / \mathrm{L}$ as N) & 00631 & CL050 & $0.10 \mathrm{mg} / \mathrm{L}$ \\
Nitrogen, total, dissolved $(\mathrm{mg} / \mathrm{L}$ and $\mathrm{N})$ & 62854 & CL063 & $0.01 \mathrm{mg} / \mathrm{L}$ \\
\hline
\end{tabular}

250-mL polyethylene bottles, all of which were prewashed and rinsed profusely prior to sample collection. Groundwater samples were filtered on site with syringe cartridge filters, or were filtered in a laboratory within 6 hours by using a peristaltic pump and a cartridge filter or a syringe and a cartridge filter. All filters were $0.45-\mu \mathrm{m}$ pore size, and all samples were filtered into $125-\mathrm{mL}$ amber polyethylene bottles that had been acid washed and rinsed three times with filtered sample prior to sample collection. Samples were chilled on ice until delivered to the USGS Maine Water Science Center (ME WSC) laboratory in Augusta, Maine, within 36 to 48 hours of collection. After arriving at the ME WSC laboratory, all samples were frozen and stored before shipment to the Woods Hole Oceanographic Institution Nutrient Analytical Facility laboratory for analysis.

Field values for specific conductance and water temperature were measured at the time of sample collection by using an Orion model 122 meter. The meter was calibrated before each use by using standard solutions for specific conductance. For surface water measurements, the Orion probe was placed directly in a fast-flowing section of the stream and allowed to equilibrate before recording the value. If the peristaltic pump was used groundwater samples were pumped into a beaker, and the Orion probe was placed into the beaker while water was being pumped in and allowed to equilibrate before readings were recorded. If the hand vacuum pump was used, water was first pumped into a vacuum flask and then poured into a beaker, the Orion probe was placed into the beaker, and readings were recorded within 30 seconds. Dissolved oxygen was determined by using a Chemetrics field test kit that uses the indigo carmine colorimetric method (Gilbert and others 1982; American Society of Testing and Materials International, 2012).

\section{Laboratory Methods for Water Quality Analysis}

Ammonia was analyzed colorimetrically by the indophenol method, Lachat QuickChem Method 31-107-060-1-B (Scheiner, 1976; American Public Health Association, 1998, method $4500-\mathrm{NH}_{3}-\mathrm{F}$, p. 4.108-4.109). Silicate was analyzed colorimetrically by using Lachat QuickChem method 31-114-27-1-C (American Public Health Association, 1998, method 4500- $\mathrm{SiO}_{2}-\mathrm{F}$, p. 4.160-4.161). Phosphate was analyzed colorimetrically by Lachat QuickChem Method 31-115-01-1-H (Murphy and Riley, 1962; American Public Health Association, 1998, method 4500-P-E, p. 4.146-4.147). Nitrate and $\mathrm{NO}_{2}$ were analyzed colorimetrically by using Lachat QuickChem Method 31-107-04-1-E (Wood and others 1967; American Public Health Association, 1998, method $4500-\mathrm{NO}_{3}-\mathrm{F}$, p. 4.118-4.119). The concentration of $\mathrm{NO}_{2}$ in these waters is expected to be below detection based on a previous study at Acadia National Park (Culbertson and others, 2007), therefore, throughout this report this analysis is referred to as $\mathrm{NO}_{3}$. Total dissolved nitrogen was analyzed colorimetrically following alkaline persulfate digestion (D'Elia and others, 1977; American Public Health Association, 1998, method 4500-Norg, p. 4.102-4.103).

\section{Ancillary Data}

Water level was recorded continuously at one site (USGS streamgage 442439068184502) in Fresh Meadow Marsh, NEC (fig. 2), using standard USGS methods. The well was equipped with a Design Analysis DH21 submersible pressure transducer 
programmed to record water level and water temperature every 15 minutes. Soil temperature and water level relative to land surface was recorded periodically at each of the denitrification measurement sites. Soil temperature was determined using a glass thermometer at a soil depth of $15 \mathrm{~cm}$ below the surface. Water level was determined by measuring the depth to the free water surface from the top of the 5 -cm-diameter piezometers, described in the preceding "Field Methods for Water Quality Sampling and Measurements" section, that were installed at each of the 12 monitoring sites and corrected for the altitude of the piezometers above land surface. Daily precipitation data were obtained from the National Park Service (NPS) at Acadia National Park. The NPS maintains a National Atmospheric Deposition Program (NADP) monitoring site that uses a Belfort tapping bucket rain gage to record daily precipitation data (http://nadp.sws.uiuc.edu/) at McFarland Hill on Mount Desert Island. The NADP program is administered by the Illinois State Water Survey in Champaign, Ill. Tidal data for Frenchmans Bay, Bar Harbor, Maine, on Mount Desert Island were obtained from National Oceanographic and Atmospheric Administration (NOAA) data files at http://tidesandcurrents.noaa.gov/. Streamwater discharge records were obtained for Otter Creek near Bar Harbor, Maine (USGS streamgage 01022840).

\section{Laboratory Denitrification Experiments to Determine $\mathbf{N}_{2}$ to $\mathbf{N}_{2} \mathbf{O}$ Ratios}

Laboratory incubation experiments using marsh soils from the NEC and BHM field measurement sites were conducted in order to determine the appropriate ratios of $\mathrm{N}_{2}$ to $\mathrm{N}_{2} \mathrm{O}$ to apply to measurements of $\mathrm{N}_{2} \mathrm{O}$ release in the field in order to obtain denitrification rates. The results of these experiments under ambient conditions (no treatment additions) and under various levels of $\mathrm{NO}_{3}$ additions with and without glucose are provided in a separate report (Huntington and others, 2011, summarized in table 4). For the experiments receiving $\mathrm{NO}_{3}$ additions, the ratios of $\mathrm{N}_{2}$ to $\mathrm{N}_{2} \mathrm{O}$ varied from 0.09 to 4.0, averaging 0.43 at NEC and 1.33 at BHM (table 4). These ratios are within the range of ratios reported in the literature for terrestrial and coastal marsh environments (Seitzinger, 1988; Weier and others, 1993; Parton and others, 1996; Lee and others, 1997; Meding and others, 2001). For example, Seitzinger (1988) reported ratios of $\mathrm{N}_{2}$ to $\mathrm{N}_{2} \mathrm{O}$ in the range of 0.18 to 2.3 for estuarine and coastal marine sediments.

The observed ratios of $\mathrm{N}_{2}$ to $\mathrm{N}_{2} \mathrm{O}$ varied considerably among sites and were generally higher in BHM than NEC (table 4). The ratios of $\mathrm{N}_{2}$ to $\mathrm{N}_{2} \mathrm{O}$ generally were substantially higher under ambient conditions or under glucose only conditions than when $\mathrm{NO}_{3}$ or $\mathrm{NO}_{3}$ plus glucose was added (table 4). However, the limited number of analyses and the high variability for these treatments indicates a high uncertainty in the actual ratios under these conditions. One of the reasons for higher variability in the ratios under ambient or glucose-only treatments is that the absolute rates of $\mathrm{N}_{2} \mathrm{O}$ release were very low under these conditions. If any substantial $\mathrm{N}_{2} \mathrm{O}$ consumption had occurred in one treatment but not in another during the incubation, that increase would have skewed the results. We did not quantify $\mathrm{N}_{2} \mathrm{O}$ consumption; rather, we measured net $\mathrm{N}_{2} \mathrm{O}$ release during the incubation period.

\section{Laboratory Denitrification Experiments to Determine Response to Nitrate and Glucose Additions}

In one experiment using soil from NEC site GW4, $\mathrm{NO}_{3}$ was added at 10 rates, ranging from 0 to $14 \mathrm{mg} \mathrm{N} \mathrm{g}^{-1}$ fresh soil with and without the addition of $3.6 \mathrm{mg}$ glucose per $\mathrm{g}$ fresh soil, and all treatments received acetylene. $\mathrm{N}_{2} \mathrm{O}$ production rates increased with increasing incubation time from 1 hour 44 minutes to 19 hours 46 minutes for all treatments (figs. 6A and $\mathrm{B}$ ). The largest increases in rates of denitrification (by factors of approximately 4 to 10) were between the third ( 3 hours 45 minutes to 5 hours 47 minutes) and fourth (5 hours 47 minutes to 19 hours 46 minutes) time intervals. These responses indicate a lag in the microbial denitrification that occurred following the treatment additions both with and without glucose additions in this NEC marsh soil. The initial rates (from $\mathrm{T}_{0}$ to 1 hour 44 minutes) were very low $\left(<10\right.$ nanomoles (nmol) $\left.\mathrm{N}_{2} \mathrm{O} \mathrm{g}^{-1} \mathrm{hr}^{-1}\right)$ in all cases. Surprisingly, no increase in denitrification rate occurred with higher $\mathrm{NO}_{3}$ concentrations at sites where no glucose was added (fig. 6A). Denitrification rates decreased linearly from about 55 to $8 \mathrm{nmol} \mathrm{N}_{2} \mathrm{O} \mathrm{g}^{-1} \mathrm{hr}^{-1}$ in response to linearly increasing $\mathrm{NO}_{3}$ additions ranging from 1.05 to $14 \mathrm{mg} \mathrm{N} \mathrm{g}^{-1}$ fresh soil (fig. 6A) indicating that $\mathrm{NO}_{3}$ addition rates greater than $1 \mathrm{mg} \mathrm{N} \mathrm{g}^{-1}$ fresh soil probably inhibited denitrification or other microbial pathways that produce $\mathrm{N}_{2} \mathrm{O}$. Inhibition of denitrification (to the end products $\mathrm{N}_{2} \mathrm{O}$ and $\mathrm{N}_{2}$ ) under conditions of high $\mathrm{NO}_{3}$ concentrations has been reported (Francis and Mankin, 1977; Glass and Silverstein, 1998). The mechanism for this inhibition may be related to toxicity from the accumulation of $\mathrm{NO}_{2}$ or of nitrous acid (Glass and Silverstein, 1998). It is unlikely that acetylene inhibition of nitrification affected production of $\mathrm{NO}_{3}$, since we typically observed no measureable rates of $\mathrm{N}_{2} \mathrm{O}$ production in field experiments when no acetylene was added. Denitrification rates at sites where glucose was added were substantially higher than at sites where no glucose was added for all $\mathrm{NO}_{3}$ treatments and for all time periods except during the initial incubation period ( $\mathrm{T}_{0}$ to 1 hour 44 minutes) (fig. 6B). The addition of glucose increased the rate of denitrification by a factor of about 4 to 5, to 200 to $300 \mathrm{nmol} \mathrm{N}_{2} \mathrm{O} \mathrm{g}^{-1} \mathrm{hr}^{-1}$ for the lower rates of $\mathrm{NO}_{3}$ addition (fig. 6B). Denitrification rates with added glucose decreased with increasing $\mathrm{NO}_{3}$ additions above $0.7 \mathrm{mg} \mathrm{N} \mathrm{g}^{-1}$ fresh soil, again indicating an inhibition of denitrification at the higher rates of $\mathrm{NO}_{3}$ addition. 
Table 4. Ratios of $\mathrm{N}_{2}$ to $\mathrm{N}_{2} \mathrm{O}$ denitrification products measured in laboratory incubation experiments using acetylene to block production of $\mathrm{N}_{2}$.

[Where experiments were not conducted, the values shown are the means of the measured values for the soils in that estuary. N, number of replicates in the experimental trials; NEC, Northeast Creek watershed; GW, locations 1 through 6 in each watershed; --, no measurements for that watershed site; BHM, Bass Harbor Marsh watershed; Standard deviations were not calculated if the number of replicates was less than three]

\begin{tabular}{|c|c|c|c|}
\hline Site name & Average & $\begin{array}{c}\mathrm{N}_{2} / \mathrm{N}_{2} \mathrm{O} \\
\text { standard deviation }\end{array}$ & $\mathbf{N}$ \\
\hline \multicolumn{4}{|c|}{ Ambient (no treatment additions) } \\
\hline NEC GW1 & 2.58 & & 2 \\
\hline NEC GW2 & 2.33 & & 2 \\
\hline NEC GW3 & 4.55 & & 1 \\
\hline NEC GW4 & 3.15 & & -- \\
\hline NEC GW5 & 2.39 & & 2 \\
\hline NEC GW6 & 3.15 & & -- \\
\hline BHM GW1 & 10.38 & 8.01 & 4 \\
\hline BHM GW2 & 1.49 & & 1 \\
\hline BHM GW3 & 5.94 & & -- \\
\hline BHM GW4 & 5.94 & & -- \\
\hline BHM GW5 & 5.94 & & -- \\
\hline BHM GW6 & 5.94 & & -- \\
\hline \multicolumn{4}{|c|}{ Nitrate added } \\
\hline NEC GW1 & 0.09 & 0.07 & 3 \\
\hline NEC GW2 & 0.12 & & 2 \\
\hline NEC GW3 & 0.32 & 0.38 & 3 \\
\hline NEC GW4 & 0.30 & & 2 \\
\hline NEC GW5 & 0.58 & 0.33 & 4 \\
\hline NEC GW6 & 1.16 & & 1 \\
\hline BHM GW1 & 1.10 & 0.70 & 5 \\
\hline BHM GW2 & 0.72 & 0.24 & 6 \\
\hline BHM GW3 & 0.64 & 0.33 & 4 \\
\hline BHM GW4 & 1.33 & & -- \\
\hline BHM GW5 & 0.21 & & 2 \\
\hline BHM GW6 & 4.00 & & 2 \\
\hline
\end{tabular}

\begin{tabular}{|c|c|c|c|}
\hline Site name & Average & $\begin{array}{c}\mathrm{N}_{2} / \mathrm{N}_{2} \mathrm{O} \\
\text { standard deviation }\end{array}$ & $\mathbf{N}$ \\
\hline \multicolumn{4}{|c|}{ Nitrate and glucose added } \\
\hline NEC GW1 & 1.66 & & -- \\
\hline NEC GW2 & 0.21 & & 2 \\
\hline NEC GW3 & 1.66 & & -- \\
\hline NEC GW4 & 1.66 & & -- \\
\hline NEC GW5 & 3.10 & & 2 \\
\hline NEC GW6 & 1.66 & & -- \\
\hline BHM GW1 & 0.70 & & -- \\
\hline BHM GW2 & 0.69 & 0.06 & 4 \\
\hline BHM GW3 & 0.94 & & 2 \\
\hline BHM GW4 & 0.70 & & -- \\
\hline BHM GW5 & 0.46 & & 1 \\
\hline BHM GW6 & 0.70 & & -- \\
\hline \multicolumn{4}{|c|}{ Glucose added } \\
\hline NEC GW1 & 11.92 & & -- \\
\hline NEC GW2 & 1.36 & & -- \\
\hline NEC GW3 & 11.92 & & -- \\
\hline NEC GW4 & 11.92 & & -- \\
\hline NEC GW5 & 22.48 & & 2 \\
\hline NEC GW6 & 11.92 & & -- \\
\hline BHM GW1 & 36.71 & & -- \\
\hline BHM GW2 & 1.13 & & 1 \\
\hline BHM GW3 & 72.29 & & 1 \\
\hline BHM GW4 & 36.71 & & -- \\
\hline BHM GW5 & 36.71 & & -- \\
\hline BHM GW6 & 36.71 & & -- \\
\hline
\end{tabular}

In another laboratory experiment using soils from NEC sites (GW1, GW2, GW3, and GW5) and from BHM sites (GW1, GW2, GW3 and GW5), $\mathrm{NO}_{3}$ was added at three rates $\left(0,1.05\right.$, and $7 \mathrm{mg} \mathrm{N} \mathrm{g}^{-1}$ fresh soil). For each rate of added $\mathrm{NO}_{3}$ there were four combinations of treatments involving acetylene and $3.6 \mathrm{mg}$ glucose $\mathrm{g}^{-1}$ fresh soil: (1) no acetylene, no glucose; (2) no acetylene, with glucose; (3) with acetylene, no glucose; and (4) with acetylene and with glucose. Complete data for these experiments have been previously reported (Huntington and others, 2011). When no $\mathrm{NO}_{3}$ was added, with or without glucose addition, in the NEC soils there was little to no $\mathrm{N}_{2} \mathrm{O}$ production unless acetylene was added (fig. 7A). When acetylene was added in these zero $\mathrm{NO}_{3}$ treatments $\mathrm{N}_{2} \mathrm{O}$ production increased to 5 to $7 \mathrm{nmol} \mathrm{N}_{2} \mathrm{O} \mathrm{g}^{-1}$ dry soil $\mathrm{hr}^{-1}$. In contrast, in the BHM sediments little to no $\mathrm{N}_{2} \mathrm{O}$ production was observed unless $\mathrm{NO}_{3}$ was added, regardless of whether acetylene or glucose were added (fig. 7B).

When $\mathrm{NO}_{3}$ was added, $\mathrm{N}_{2} \mathrm{O}$ production increased markedly in all cases (typically to between 10 and $50 \mathrm{nmol} \mathrm{N}_{2} \mathrm{O}$ $\mathrm{g}^{-1}$ dry soil $\mathrm{hr}^{-1}$ ) depending on the site and on whether glucose or acetylene had been added (figs. 7A and B). The rate of $\mathrm{N}_{2} \mathrm{O}$ production was substantially higher during the second incubation period ( 3 hours 53 minutes to 7 hours 54 minutes) after initiation of the incubation compared to the first incubation period ( $\mathrm{T}_{0}$ to 3 minutes 53 minutes) for most treatments, although the differences between these sequential periods were smaller in NEC soils than in BHM soils (fig. 7). Generally, the rates of $\mathrm{N}_{2} \mathrm{O}$ production were higher in response to 


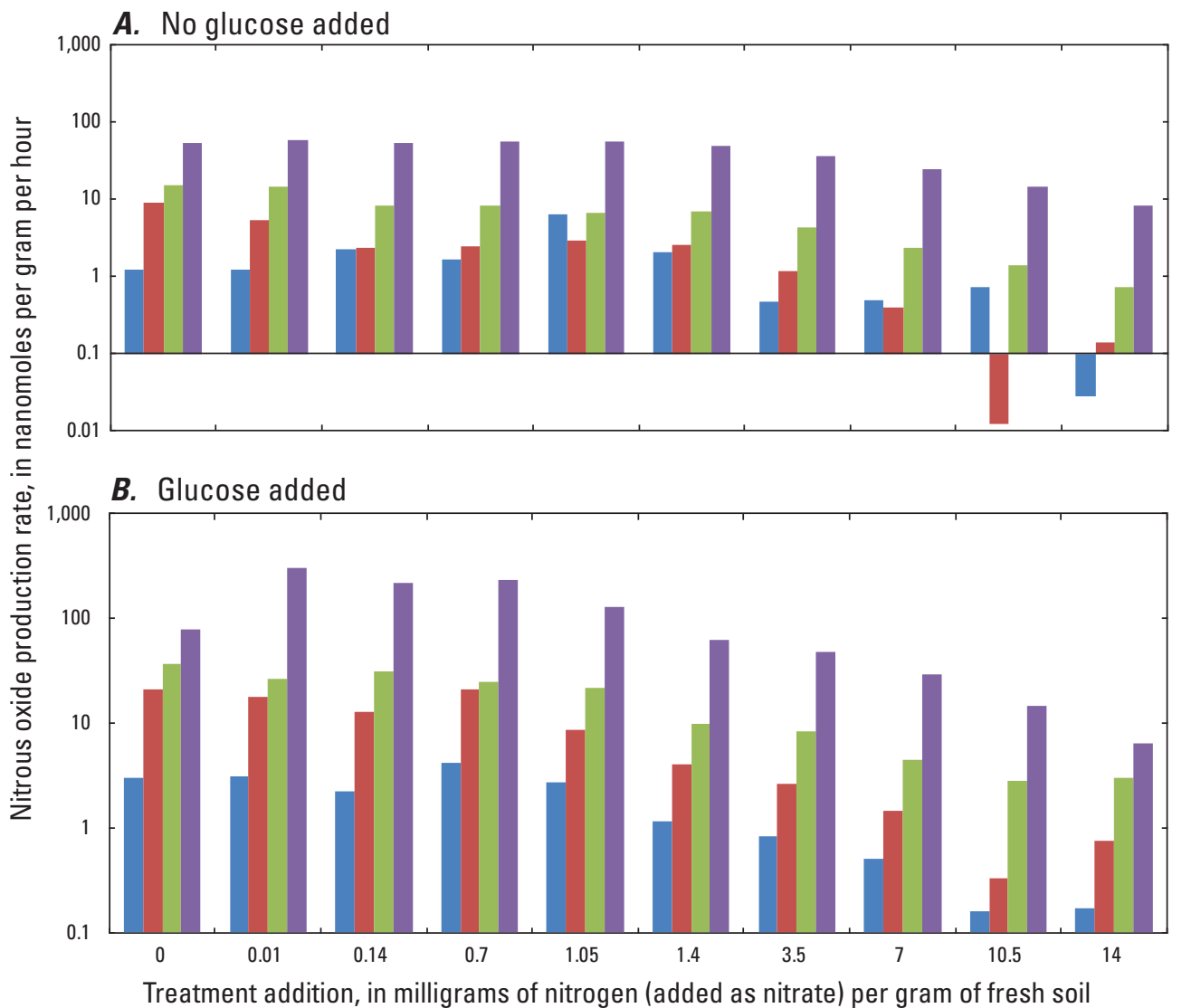

EXPLANATION

Incubation intervals, in hours:minutes

0:00 to 1:44 1:44 to $3: 45-3: 34$ to $5: 47 \quad 5: 47$ to $19: 46$

Figure 6. Production rates of nitrous oxide in the laboratory determined after the indicated incubation intervals with $A$, no glucose added and $B$, glucose added at 3.6 grams per square meter of fresh soil. Soil samples are from Northeast Creek watershed site GW4. Location of site shown in figure 3.

the addition of $1.05 \mathrm{mg} \mathrm{N} \mathrm{g}^{-1}$ fresh soil than after adding $7 \mathrm{mg}$ $\mathrm{N} \mathrm{g}^{-1}$ fresh soil for both BHM and NEC soils. The reduction in $\mathrm{N}_{2} \mathrm{O}$ production at the higher rate of $\mathrm{N}$ addition was more pronounced in the NEC soils than in the BHM soils. It is likely that the higher rates of $\mathrm{N}$ addition resulted in some inhibition of denitrification.

The addition of acetylene resulted in an increase in the rate of $\mathrm{N}_{2} \mathrm{O}$ production for all treatments during which $\mathrm{NO}_{3}$ was added and in the zero $\mathrm{NO}_{3}$ treatments in NEC soils (fig. 7), as expected, because acetylene blocks the conversion of $\mathrm{N}_{2} \mathrm{O}$ (produced during the first step in denitrification) to $\mathrm{N}_{2}$. The fact that little to no $\mathrm{N}_{2} \mathrm{O}$ production was observed in the treatments in which no $\mathrm{NO}_{3}$ was added, but that $\mathrm{N}_{2} \mathrm{O}$ was produced when acetylene was added, confirms that net
$\mathrm{N}_{2} \mathrm{O}$ production did not occur at measurable rates under these laboratory conditions unless $\mathrm{NO}_{3}$ was added. There was either little to no production of $\mathrm{N}_{2} \mathrm{O}$, or the production of $\mathrm{N}_{2} \mathrm{O}$ was balanced by $\mathrm{N}_{2} \mathrm{O}$ consumption during these incubations. The proportional increase in $\mathrm{N}_{2} \mathrm{O}$ production in the treatments that added acetylene compared with adding no acetylene was not influenced by the addition of glucose in any of the treatments in which $\mathrm{NO}_{3}$ was added (figs. 7A and $\mathrm{B}$ ).

The addition of 3.6-mg glucose $\mathrm{g}^{-1}$ fresh soil increased $\mathrm{N}_{2} \mathrm{O}$ production in all treatments in which $\mathrm{NO}_{3}$ was added and in the zero $\mathrm{NO}_{3}$ treatment on NEC soils in which acetylene was added (fig. 7A). The glucose-induced increase in $\mathrm{N}_{2} \mathrm{O}$ production was greater during the second incubation period (3 hours 53 minutes to 7 hours 54 minutes) during which $\mathrm{NO}_{3}$ 
A. Northeast Creek watershed

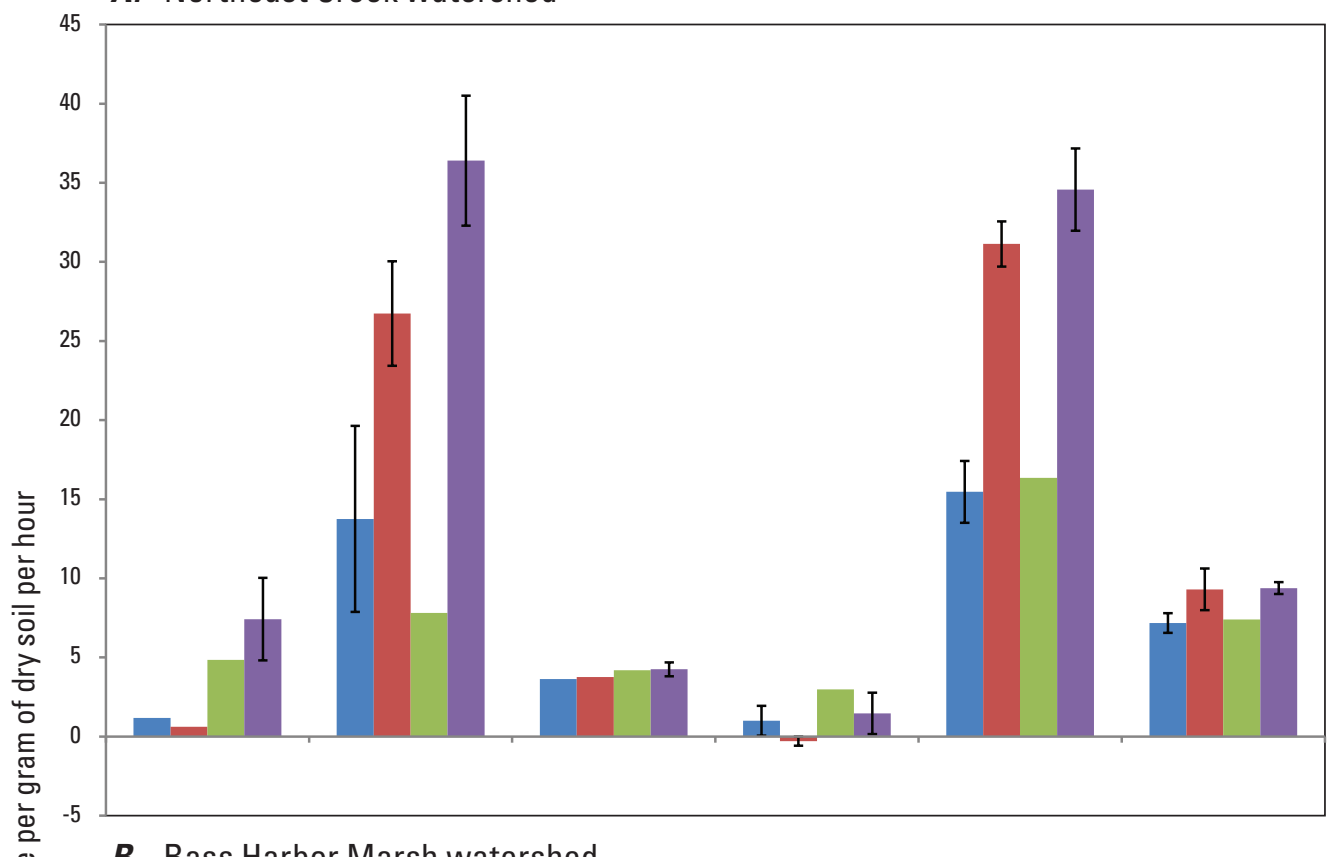

B. Bass Harbor Marsh watershed

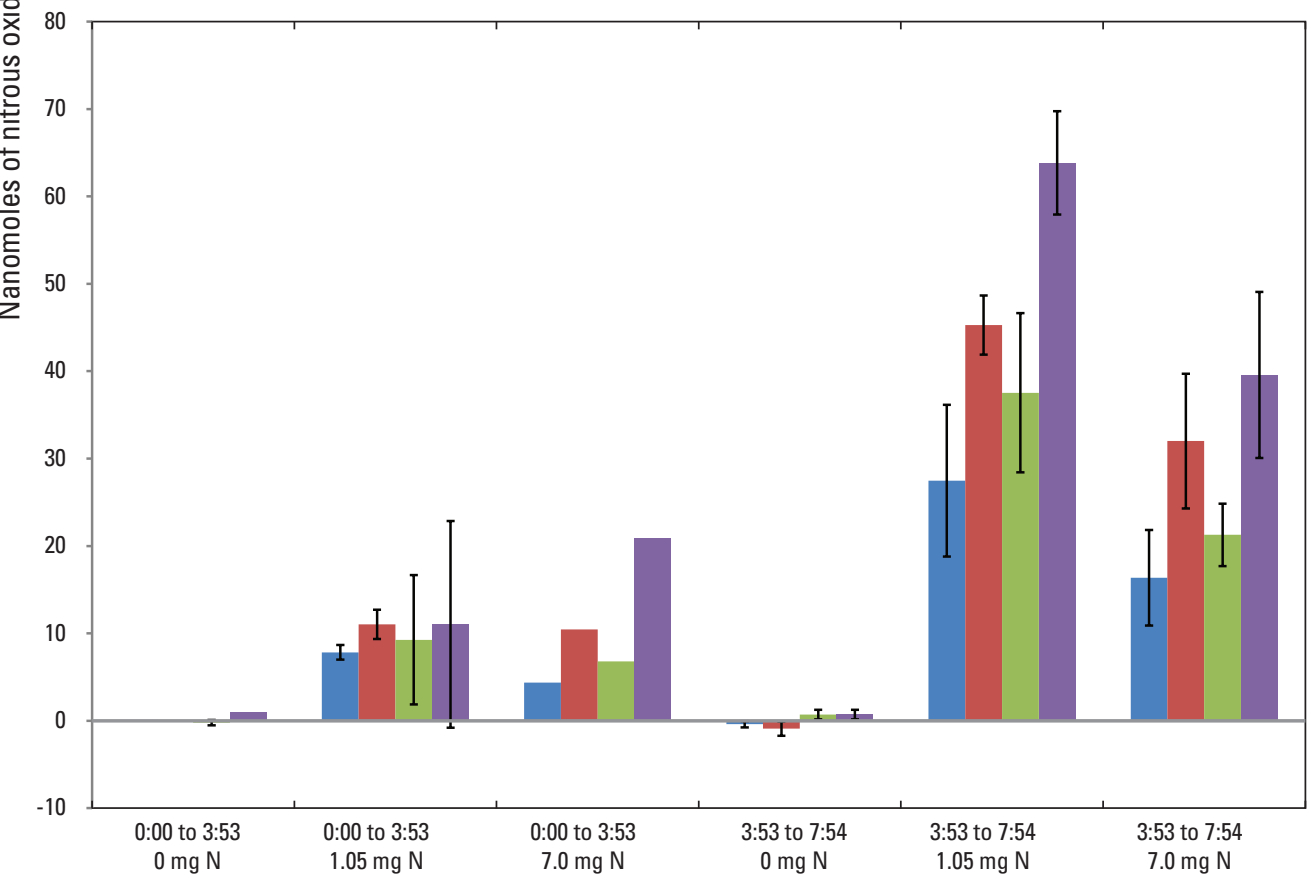

Incubation interval, in hours:minutes, and mass of nitrogen $(\mathrm{N})$ added, in milligrams $(\mathrm{mg})$

\section{EXPLANATION}

Neither acetylene nor glucose added

Glucose added, acetylene not added

Acetylene added, glucose not added

Both acetylene and glucose added

Figure 7. Laboratory nitrous oxide production rates following nitrate, glucose, and acetylene addition treatment additions after the indicated incubation intervals for $A$, Northeast Creek watershed sites GW2, GW3, and GW5 and B, Bass Harbor Marsh watershed sites GW1, GS2, and GW3. Location of site shown in figure 3. 
was added, compared to the first period ( $\mathrm{T}_{0}$ to 3 hours $53 \mathrm{~min}$ utes) (fig. 7A). The increasing $\mathrm{N}_{2} \mathrm{O}$ production in response to added glucose suggests that denitrification at these marsh soils may be limited by the availability of labile carbohydrates as well as by the availability of $\mathrm{NO}_{3}$. Alternatively, the addition of glucose could have stimulated bacterial growth that, in turn, lowered the oxygen concentration, resulting in conditions more favorable for denitrification.

The fact that measured $\mathrm{N}_{2} \mathrm{O}$ production generally was higher during the second incubation period ( 3 hours 53 minutes to 7 hours 54 minutes) compared with the first period ( $\mathrm{T}_{0}$ to 3 hours 53 minutes) probably indicates a lag in the microbial response to the $\mathrm{NO}_{3}$ addition treatments. The addition of glucose did not appear to affect whether a lag occurred or how pronounced the lag was. In one experiment using soils from one NEC site, the incubations were extended an additional 15 hours and 15 minutes. In this experiment, in all cases in which $\mathrm{NO}_{3}$ was added $\left(1.05 \mathrm{mg} \mathrm{N} \mathrm{g}^{-1}\right.$ and $7 \mathrm{mg} \mathrm{N} \mathrm{g}^{-1}$ fresh soil with and without glucose and with and without acetylene), the $\mathrm{N}_{2} \mathrm{O}$ production rates during the third incubation period (7 hours 54 minutes to 23 hours 9 minutes) were substantially higher than those observed in the second period (data reported in Huntington and others, 2011). In this extended incubation period experiment, for the treatments where no $\mathrm{NO}_{3}$ was added, $\mathrm{N}_{2} \mathrm{O}$ production rates decreased from the first through the third incubation periods regardless of the addition of glucose or of acetylene, thus emphasizing the lack of denitrification activity at sites where no $\mathrm{NO}_{3}$ was added rather than attributing the decrease to a simple lag in activity.

\section{Field Measurements of Denitrification Under Ambient Conditions}

Preliminary measurements at NEC in May and June 2008 indicated that there was a lag in the release of a detectable amount of $\mathrm{N}_{2} \mathrm{O}$ in the chambers so that, during most of the experiments samples were not collected until 2 to 4 hours after the chambers were sealed. During 2008, preliminary measurements at NEC indicated that the addition of acetylene alone (without $\mathrm{NO}_{3}$ ) resulted in no measurable release of $\mathrm{N}_{2} \mathrm{O}$ (Huntington and others, 2011). Therefore, acetylene was not used in any further field experiments. To calculate the denitrification rate during the initial period following the sealing of the chambers and the collection of the first gas samples, the study assumed the initial headspace concentration of $\mathrm{N}_{2} \mathrm{O}$ to be zero. All the field measurements of denitrification rates reported in this section are the result of measured $\mathrm{N}_{2} \mathrm{O}$ release and of applying the laboratory-determined, site-specific ratio of $\mathrm{N}_{2}: \mathrm{N}_{2} \mathrm{O}$. At NEC and BHM watersheds, average initial denitrification rates (following the sealing of chambers to the marsh surface) under ambient conditions were relatively low (between 0 and 26 micromoles $(\mu \mathrm{mol}) \mathrm{N}_{2} \mathrm{O}$ per square meter per hour $\left.\left(\mathrm{m}^{-2} \mathrm{hr}^{-1}\right)\right)$ (table 5). After the initial periods, average measured denitrification rates under ambient conditions were typically between 0 and $3 \mu \mathrm{mol} \mathrm{m}{ }^{-2} \mathrm{hr}^{-1}$ (table 5). The apparent initial rates generally were not sustained after the first few hours during these incubations, suggesting that the minimal $\mathrm{N}_{2} \mathrm{O}$ production was balanced by microbial consumption of $\mathrm{N}_{2} \mathrm{O}$ such that $\mathrm{N}_{2} \mathrm{O}$ concentration in the chamber headspace did not continue to increase.

Although methodological differences caution against interpretations based on comparisons with denitrification rates reported in other studies (Groffman and others, 2006; Seitzinger and others, 2006), that broader context of rates determined in other environments provides a useful framework to assess results from studies in environments that have never been monitored. The observed rates under ambient conditions at NEC and BHM are somewhat lower than those that Greene (2005) reported (39 to $95 \mu \mathrm{mol} \mathrm{m}^{-2}$ $\mathrm{hr}^{-1}$ ) in a review of freshwater wetland, mudflat, and coastal wetland studies. The denitrification rates under ambient conditions in NEC and BHM are comparable to, or somewhat higher than, rates that Tobias and Neubauer (2009) reported for salt marsh ecosystems having low to moderate ambient $\mathrm{NO}_{3}$ concentrations ( 0 to $50 \mathrm{mM} \mathrm{NO}_{3}$ ). However, these rates at NEC and BHM are somewhat lower than the rates the same authors reported for salt marshes having high ambient $\mathrm{NO}_{3}$ concentrations ( $>50 \mu \mathrm{M} \mathrm{NO}_{3}$ ), which ranged was from 0 to $100 \mu \mathrm{mol} \mathrm{m}^{-2} \mathrm{hr}^{-1}$ (Tobias and Neubauer, 2009). The same review of denitrification in salt marshes reported that, in spite of large variability among sites, an overall positive relationship exists between ambient $\mathrm{NO}_{3}$ concentrations in pore waters and denitrification rates. In the context of the reports of these other studies, the marsh soils in NEC and $\mathrm{BHM}$ are in the low to moderate ranges for denitrification and for $\mathrm{NO}_{3}$ concentration.

During these experiments under ambient conditions, subsequent sampling of chamber headspace gas at periodic intervals up to about 24 hours after chamber sealing generally did not result in higher measured denitrification rates; in fact, rates usually declined over time (table 5). The data on $\mathrm{N}_{2} \mathrm{O}$ production rate for each measurement date and site are published in Huntington and others (2011). Denitrification rates during successive time intervals following chamber sealing $\left(\mathrm{T}_{0}\right)$ are presented for NEC sites GW4 and GW2 in July 2008, illustrating the average rate during time intervals $\mathrm{T}_{0}$ to 4 hours 36 minutes, 4 hours 36 minutes to 7 hours 20 minutes, 7 hours 20 minutes to 11 hours 20 minutes, and 11 hours 20 minutes to 22 hours 59 minutes (fig. 8A). The rates over time were either relatively constant (NEC GW4) or, more typically, decreased to near zero (NEC GW2) (fig. 8A). Similar results, in that rates either did not increase or decreased over time, were observed for sequential time periods following chamber sealing during July and August 2009 at BHM, where results were averaged for sites GW1 through GW6 (fig. 8B). We assume that the $\mathrm{N}_{2}: \mathrm{N}_{2} \mathrm{O}$ ratios do not change over time. If these ratios changed over time that could account for some of the changes in rates that we observed. 
Table 5. Denitrification rates for each month, year, and site under ambient (no treatment additions) and following treatments where nitrate was added alone or in combination with glucose.

[For the ambient measurements, the chamber headspace concentrations were assumed to be zero at time zero ( $\mathrm{T}_{0}$ ). NEC, Northeast Creek watershed, GW, locations 1 through 6 in each watershed, BHM, Bass Harbor Marsh; g, grams; N, nitrogen, $\mu$ mole, micromole; hr, hour; yr, year]

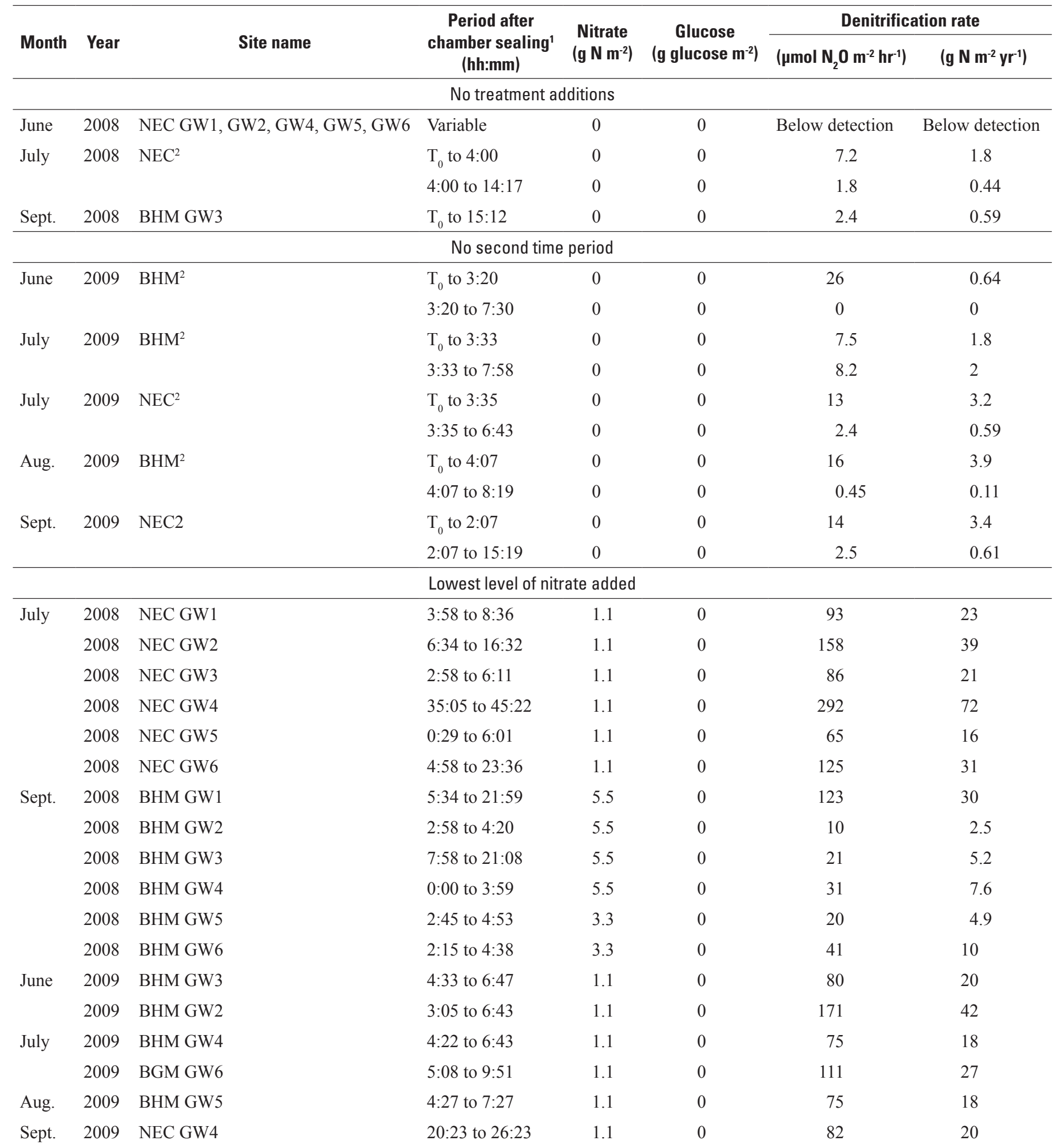


Table 5. Denitrification rates for each month, year, and site under ambient (no treatment additions) and following treatments where nitrate was added alone or in combination with glucose.-Continued

[For the ambient measurements, the chamber headspace concentrations were assumed to be zero at time zero $\left(\mathrm{T}_{0}\right)$. NEC, Northeast Creek watershed, GW, locations 1 through 6 in each watershed, BHM, Bass Harbor Marsh; g, grams; N, nitrogen, $\mu$ mole, micromole; hr, hour; yr, year]

\begin{tabular}{|c|c|c|c|c|c|c|c|}
\hline \multirow[b]{2}{*}{ Month } & \multirow[b]{2}{*}{ Year } & \multirow[b]{2}{*}{ Site name } & \multirow{2}{*}{$\begin{array}{c}\text { Period after } \\
\text { chamber sealing } \\
\text { (hh:mm) }\end{array}$} & \multirow{2}{*}{$\begin{array}{l}\text { Nitrate } \\
\left(\mathrm{g} \mathrm{N} \mathrm{m}^{-2}\right)\end{array}$} & \multirow{2}{*}{$\begin{array}{c}\text { Glucose } \\
\text { (g glucose } \mathrm{m}^{-2} \text { ) }\end{array}$} & \multicolumn{2}{|c|}{ Denitrification rate } \\
\hline & & & & & & $\left(\mu \mathrm{mol} \mathrm{N}_{2} \mathrm{O} \mathrm{m}^{-2} \mathrm{hr}^{-1}\right)$ & $\left(\mathrm{g} \mathrm{N} \mathrm{m}^{-2} \mathrm{yr}^{-1}\right)$ \\
\hline \multicolumn{8}{|c|}{ Maximum observed rate of denitrification } \\
\hline \multirow[t]{6}{*}{ July } & 2008 & NEC GW1 & $3: 58$ to $8: 36$ & 1.1 & 0 & 93 & 23 \\
\hline & 2008 & NEC GW2 & $6: 34$ to $16: 32$ & 1.1 & 0 & 158 & 39 \\
\hline & 2008 & NEC GW3 & $2: 58$ to $6: 11$ & 1.1 & 0 & 86 & 21 \\
\hline & 2008 & NEC GW4 & $35: 05$ to $45: 22$ & 1.1 & 0 & 292 & 72 \\
\hline & 2008 & NEC GW5 & $0: 29$ to $6: 01$ & 1.1 & 0 & 65 & 16 \\
\hline & 2008 & NEC GW6 & $4: 58$ to $23: 36$ & 1.1 & 0 & 125 & 31 \\
\hline \multirow[t]{6}{*}{ Sept. } & 2008 & BHM GW1 & $5: 34$ to $21: 59$ & 5.5 & 0 & 123 & 30 \\
\hline & 2008 & BHM GW2 & $2: 58$ to $4: 20$ & 5.5 & 0 & 10 & 2.5 \\
\hline & 2008 & BHM GW3 & $4: 40$ to $7: 55$ & 22 & 0 & 99 & 24 \\
\hline & 2008 & BHM GW4 & $0: 00$ to $3: 59$ & 5.5 & 0 & 63 & 15 \\
\hline & 2008 & BHM GW5 & $2: 45$ to $4: 53$ & 3.3 & 0 & 111 & 27 \\
\hline & 2008 & BHM GW6 & $2: 15$ to $4: 38$ & 3.3 & 0 & 75 & 18 \\
\hline Oct. & 2008 & BHM GW6 & $22: 39$ to $24: 25$ & 110 & 0 & 129 & 32 \\
\hline \multirow[t]{4}{*}{ June } & 2009 & BHM GW3 & $6: 09$ to $16: 52$ & 55 & 0 & 258 & 63 \\
\hline & 2009 & BHM GW3 & $9: 53$ to $22: 03$ & 55 & 213 & 477 & 120 \\
\hline & 2009 & BHM GW2 & $6: 10$ to $27: 02$ & 110 & 0 & 327 & 80 \\
\hline & 2009 & BHM GW2 & $2: 41$ to $6: 19$ & 110 & 213 & 475 & 120 \\
\hline \multirow[t]{4}{*}{ July } & 2009 & BGM GW4 & $4: 12$ to $6: 33$ & 110 & 0 & 522 & 130 \\
\hline & 2009 & BGM GW4 & $4: 04$ to $6: 25$ & 110 & 213 & 581 & 140 \\
\hline & 2009 & BGM GW6 & $5: 00$ to $9: 43$ & 55 & 0 & 785 & 190 \\
\hline & 2009 & BGM GW6 & $9: 33$ to $21: 28$ & 110 & 213 & 541 & 130 \\
\hline \multirow[t]{2}{*}{ Aug. } & 2009 & BHM GW5 & $7: 19$ to $19: 211$ & 44 & 0 & 168 & 41 \\
\hline & 2009 & BHM GW5 & $4: 07$ to $7: 33$ & 5.5 & 213 & 680 & 170 \\
\hline \multirow[t]{2}{*}{ Sept. } & 2009 & NEC GW4 & $20: 23$ to $26: 18$ & 5.5 & 0 & 133 & 33 \\
\hline & 2009 & NEC GW4 & $20: 24$ to $26: 19$ & 44 & 213 & 489 & 120 \\
\hline
\end{tabular}

${ }^{1}$ The periods are bounded by the sampling times, after sealing chambers, over which the rates were calculated based on the increase in concentration of $\mathrm{N}_{2} \mathrm{O}$ in the headspace and application of the appropriate $\mathrm{N}_{2}$ to $\mathrm{N}_{2} \mathrm{O}$ ratio. The times are averages for all replicates for each treatment.

${ }^{2} \mathrm{GW} 1$ through GW6 averaged together. 

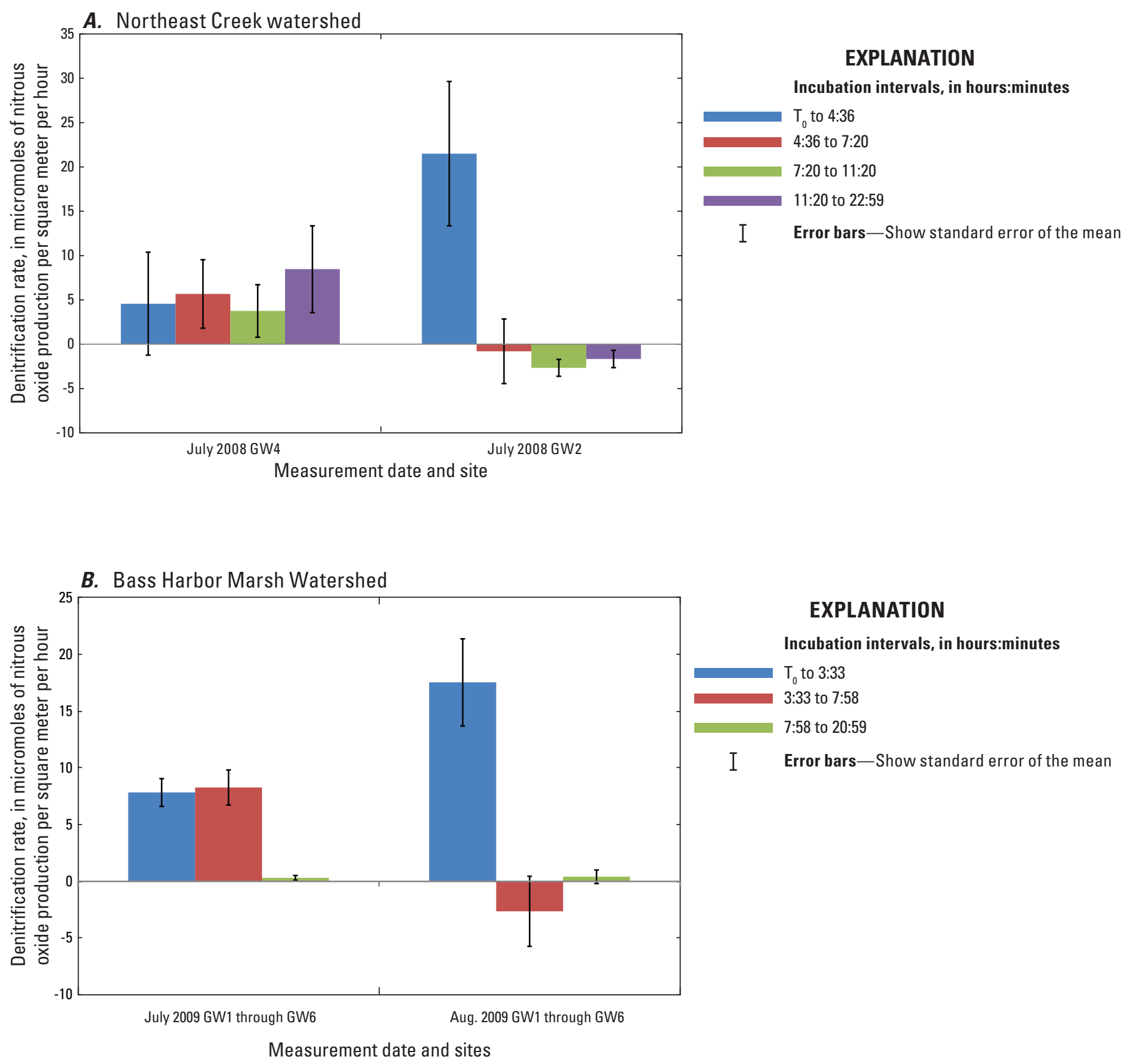

Figure 8. A, Average of the field denitrification rates for sites GW4 and GW2, July 2008 in the Northeast Creek watershed. B, Average of the field denitrification rates for sites GW1-GW6, July and August 2009 in the Bass Harbor Marsh watershed. For both figures denitrification rates were for ambient conditions during sequential periods following the time chambers were sealed to the marsh soil surface. Initial rates were calculated assuming sealing time $\left(\mathrm{T}_{0}\right)$ as being zero nanomoles of nitrous oxide per milliliter. Location of site shown in figure 3. 
Field Measurements of Denitrification Following Nitrate and Glucose Addition Treatments

Denitrification rates generally increased by an order of magnitude or more following $\mathrm{NO}_{3}$ additions, with or without glucose additions, compared with the ambient treatments that received no nutrient additions (table 5). Denitrification rates generally increased with increasing rates of added $\mathrm{NO}_{3}$, although the response was not linear, and in some cases rates were lower at the highest $\mathrm{NO}_{3}$ addition rates compared with low to moderate $\mathrm{NO}_{3}$ addition rates. Flooded conditions during most of 2009 (fig. 9A) limited our ability to make denitrification measurements in response to variable rates of $\mathrm{NO}_{3}$ addition on NEC until September 2009. In Fresh Meadow Marsh, where our denitrification measurement sites were located, the water level in Northeast Creek was at or above the ground surface nearly continuously from June through December in 2009 (fig. 9A). These persistent flooded conditions in Fresh Meadow Marsh had never been observed before by Acadia National Park resource managers or by USGS scientists working in this area for many years. The timing and amplitude of changes in water level in Fresh Meadow Marsh corresponded closely to the measured discharge at Otter Creek (USGS streamgage 01022840). Mount Desert Island received an unprecedented amount of rainfall during this period (fig. 9B).

In June 2009 the BHM sites GW2 and GW3 showed large increases in denitrification rates in the range of 1.1 to $11 \mathrm{~g} \mathrm{~N} \mathrm{~m}^{-2}$, in response to $\mathrm{NO}_{3}$ additions (when no glucose was added) but these sites showed no increase in denitrification rates in response to $\mathrm{NO}_{3}$ additions greater than $55 \mathrm{~g} \mathrm{~N} \mathrm{~m}^{-2}$
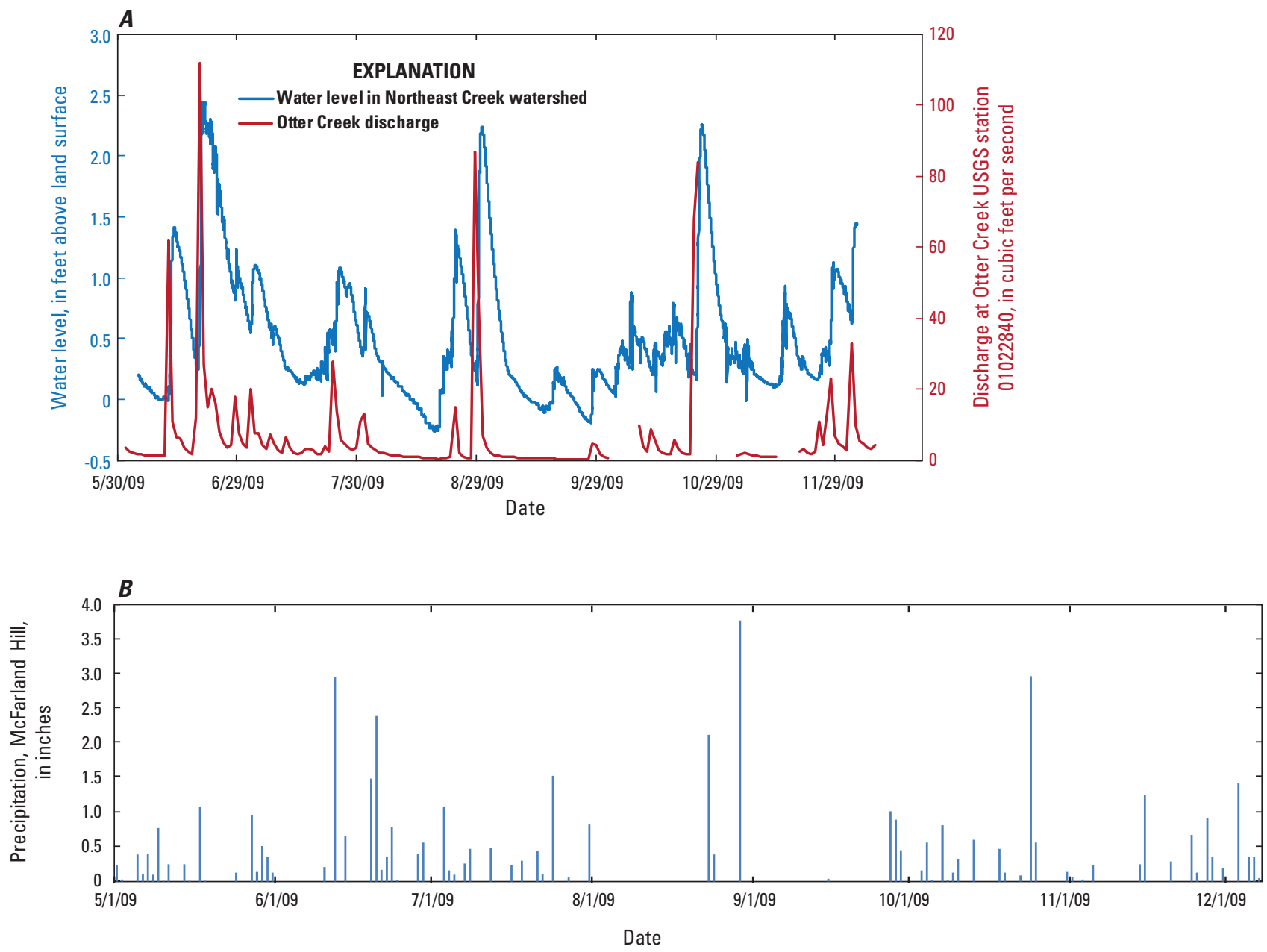

Figure 9. A, Water levels in the Fresh Meadow Marsh, Northeast Creek watershed, Mount Desert Island, Maine, and discharge at Otter Creek U.S. Geological Survey (USGS) streamgage 01022840; and B, daily precipitation at the McFarland Hill weather station, near Bar Harbor, Mount Desert Island, Maine. 
(figs. 10 and 11). The BHM site GW4 in July 2009 illustrates large increases in denitrification in response to moderate rates of $\mathrm{NO}_{3}$ addition $\left(1.1,5.5\right.$, and $\left.11 \mathrm{~g} \mathrm{~N} \mathrm{~m}^{-2}\right)$ followed by proportionately smaller increases in denitrification rate at higher rates of $\mathrm{NO}_{3}$ addition $\left(22,55\right.$ and $110 \mathrm{~g} \mathrm{~N} \mathrm{~m}^{-2}$ ) (fig. 12). At the BHM site GW6 in July 2009, denitrification rates increased initially from near zero to about $190 \mu \mathrm{mol} \mathrm{N}_{2} \mathrm{O} \mathrm{m}^{-2} \mathrm{hr}^{-1}$ in response to the addition of $5.5 \mathrm{~g} \mathrm{~N} \mathrm{~m}^{-2}$, did not increase above $200 \mu \mathrm{mol} \mathrm{N}_{2} \mathrm{O} \mathrm{m}^{-2} \mathrm{hr}^{-1}$ for additions of 11 and $22 \mathrm{~g} \mathrm{~N} \mathrm{~m}^{-2}$, then increased to nearly $800 \mu \mathrm{mol} \mathrm{N} \mathrm{O} \mathrm{m}^{-2} \mathrm{hr}^{-1}$ with the addition of $55 \mathrm{~g} \mathrm{~N} \mathrm{~m}^{-2}$, but then decreased to $300 \mu \mathrm{mol} \mathrm{N}_{2} \mathrm{O} \mathrm{m}^{-2} \mathrm{hr}^{-1}$ in response to $\left(110 \mathrm{~g} \mathrm{~N} \mathrm{~m}^{-2}\right)$, the highest rate of addition of nitrate (fig. 13). In August 2009, denitrification at the BHM
GW5 site increased from near zero to greater than $150 \mu \mathrm{mol}$ $\mathrm{N}_{2} \mathrm{O} \mathrm{m}^{-2} \mathrm{hr}^{-1}$ in response to $\mathrm{NO}_{3}$ additions of as much as $11 \mathrm{~g} \mathrm{~N}$ $\mathrm{m}^{-2}$ and did not increase further in response to $\mathrm{NO}_{3}$ additions of 22 or $44 \mathrm{~g} \mathrm{~N} \mathrm{~m}^{-2}$ (fig. 14). In September 2009, denitrification rates on site NEC GW4 increased from near zero to $65 \mu \mathrm{mol}$ $\mathrm{N}_{2} \mathrm{O} \mathrm{m}^{-2} \mathrm{hr}^{-1}$ in response to $\mathrm{NO}_{3}$ additions of as much as $5.5 \mathrm{~g} \mathrm{~N} \mathrm{~m}^{-2}$, then gradually declined to $40 \mu \mathrm{mol} \mathrm{N}_{2} \mathrm{O} \mathrm{m}^{-2} \mathrm{hr}^{-1}$ in response to increasing $\mathrm{NO}_{3}$ additions from 11 to $44 \mathrm{~g} \mathrm{~N} \mathrm{~m}^{-2}$ (fig. 15).

The addition of glucose at a fixed rate of $213 \mathrm{~g} \mathrm{~m}^{-2}$ in association with the added $\mathrm{NO}_{3}$ resulted in a variety of responses in denitrification rate compared with the addition of $\mathrm{NO}_{3}$ alone. In some cases the addition of glucose resulted
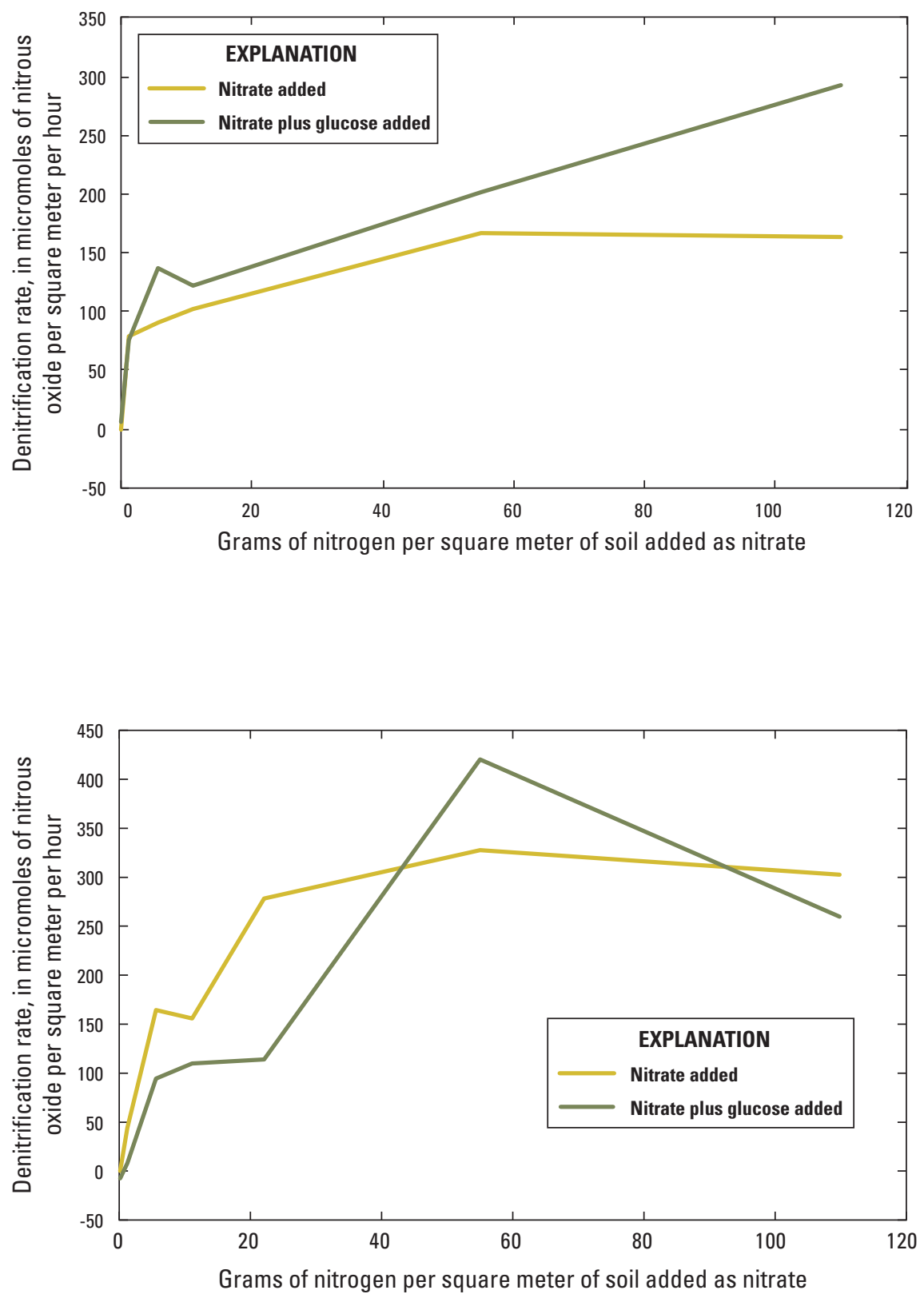

Figure 10. Average rate of denitrification over the measurement period from 3 hours 5 minutes to 20 hours 32 minutes after sealing chamber to marsh sediment surface at Bass Harbor Marsh watershed site GW2 in June 2009.

Figure 11. Average rate of denitrification over measurement period from 4 hours 33 minutes to 22 hours 32 minutes after sealing chamber to marsh sediment surface at Bass Harbor Marsh watershed site GW3 in June 2009. 

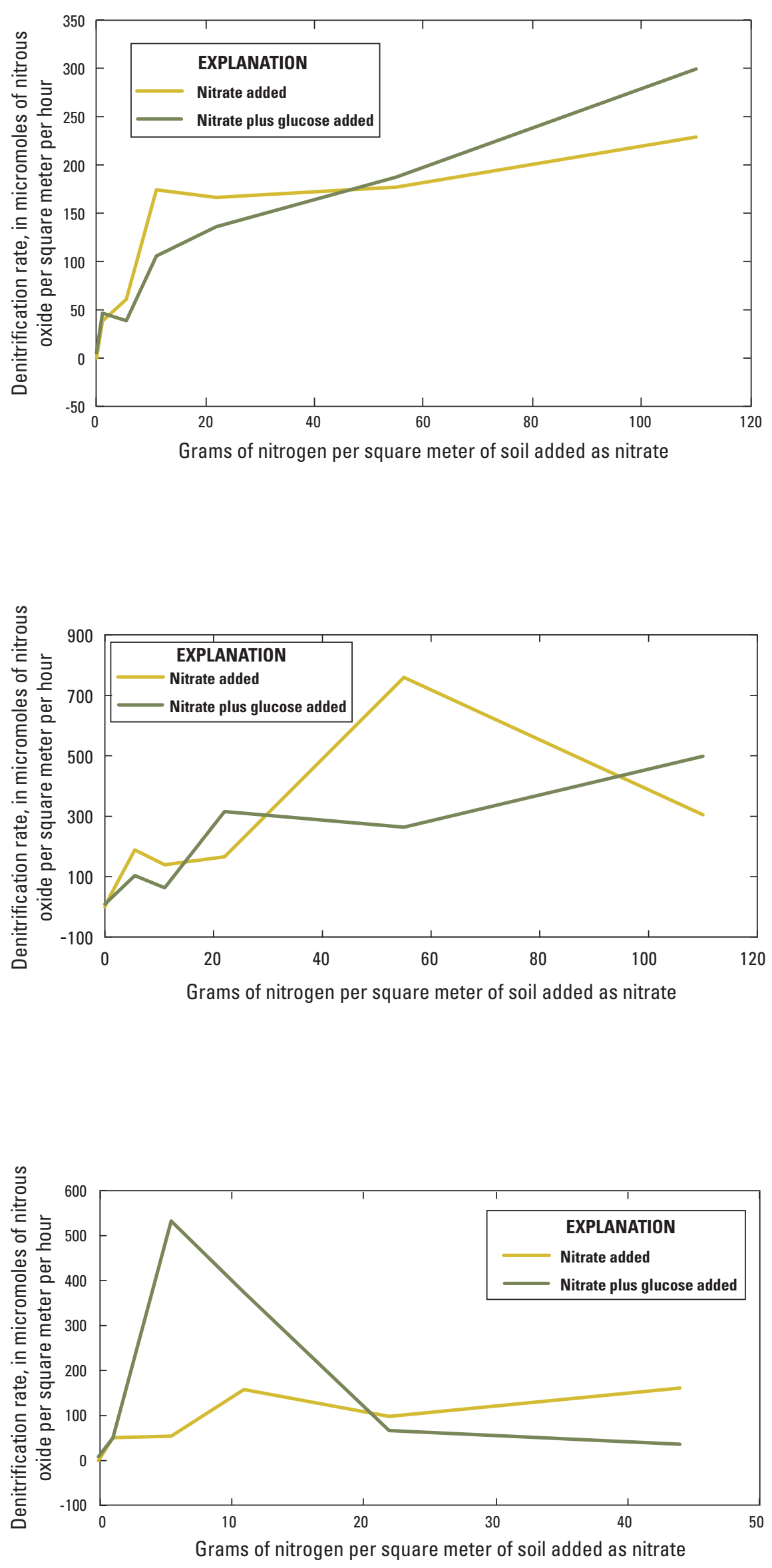

Figure 12. Average rate of denitrification over measurement period from 4 hours 22 minutes to 22 hours 01 minutes after sealing chamber to marsh sediment surface on Bass Harbor Marsh watershed site GW4 in July 2009.

Figure 13. Average rate of denitrification over measurement period from 5 hours 8 minutes to 22 hours 43 minutes after sealing chamber to marsh sediment surface on Bass Harbor Marsh watershed site GW6 in July 2009.

Figure 14. Average rate of denitrification over measurement period from 4 hours 27 minutes to 19 hours 32 minutes after sealing chamber to marsh sediment surface at Bass Harbor Marsh watershed site GW5 in August 2009. 


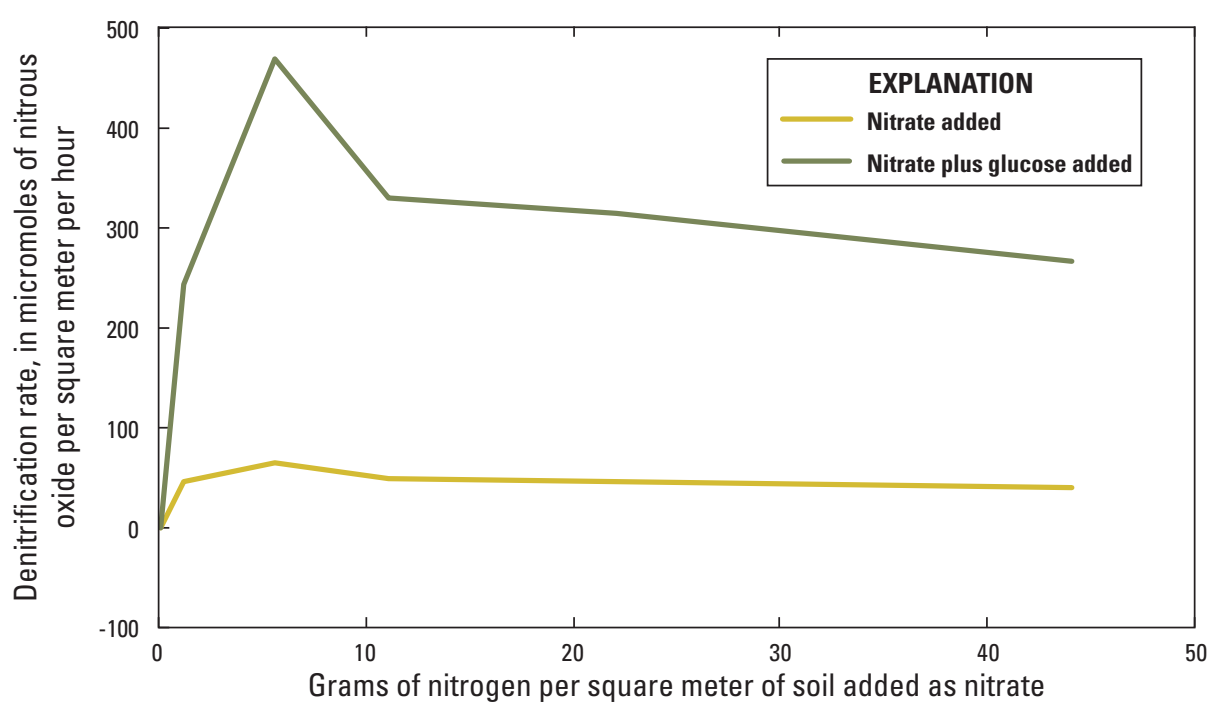

Figure 15. Average rate of denitrification over measurement period from 2 hours 51 minutes to 26 hours 16 minutes after sealing chamber to marsh sediment surface at Northeast Creek watershed site GW4 in September 2009. in higher rates of denitrification in response to a given rate of $\mathrm{NO}_{3}$ addition (for example, figs. 10, 12, 14, and 15). In some cases, the largest increases in denitrification rate in response to the added $\mathrm{NO}_{3}$ plus glucose occurred at the highest rates of $\mathrm{NO}_{3}$ addition (for example, figs. 10, 12, and 13). In August 2009 at the BHM GW5 site the largest enhancement from glucose was in response to the 5 and $11 \mathrm{~g} \mathrm{~N} \mathrm{~m}^{-2}$ rates of $\mathrm{NO}_{3}$ addition, but at the highest $\mathrm{NO}_{3}$ addition rate $(44 \mathrm{~g} \mathrm{~N}$ $\mathrm{m}^{-2}$ ), denitrification rates were higher when $\mathrm{NO}_{3}$ was added without glucose (fig. 14). At the NEC GW4 site in September 2009 , enhanced denitrification rates (by a factor of about 6) in response to glucose additions were consistently evident at all rates of $\mathrm{NO}_{3}$ addition from 1.1 to $44 \mathrm{~g} \mathrm{~N} \mathrm{~m}^{-2}$ (fig. 15). These variable responses to the addition of glucose indicate that the amount of labile carbohydrates can limit denitrification even if $\mathrm{NO}_{3}$ is present. However, there are obviously other conditions in which the addition of glucose did not result in an increase in denitrification rates, indicating that glucose was not limiting under those conditions or that glucose had no effect on oxygen concentration. For example, glucose had relatively little effect on denitrification rate in June 2009 at BHM GW2 (fig. 10) and in July 2009 at BHM GW4 (fig. 12) at the lower levels of $\mathrm{NO}_{3}$ addition, but adding glucose at the highest rate of $\mathrm{NO}_{3}$ resulted in an increased rate of denitrification. This variable response could indicate that insufficient $\mathrm{NO}_{3}$ limited denitrification only until $\mathrm{NO}_{3}$ was supplied at rates greater than or equal to $55 \mathrm{~g}$ $\mathrm{N} \mathrm{m}^{-2}$ after which, denitrification was limited by both $\mathrm{NO}_{3}$ and glucose.

Denitrification rates varied with time during the course of each measurement after sealing the chambers to the marsh surface. These variations were apparent among sites in the same watershed, between watersheds, among levels of $\mathrm{NO}_{3}$ addition, and between treatments with and without glucose additions. The largest differences in these time series were between the BHM and NEC marsh systems. In general, for all levels of $\mathrm{NO}_{3}$ addition, with and without glucose, denitrification rates increased linearly with time during measurements in NEC at site GW4 in September 2009, between measurement intervals that were bounded by the times of sampling headspace gas (fig. 16). The initial rates during the first 2 to 3 hours were quite low but they increased to maximum rates of $758 \mu \mathrm{mol} \mathrm{N}_{2} \mathrm{O} \mathrm{m}^{-2} \mathrm{hr}^{-1}$ at sites where glucose was added and increased to $132 \mu \mathrm{mol} \mathrm{N}_{2} \mathrm{O} \mathrm{m}^{-2} \mathrm{hr}^{-1}$ at sites where glucose was not added when $\mathrm{NO}_{3}$ was added at $5.5 \mathrm{~g} \mathrm{~N} \mathrm{~m}^{-2}$ (fig. 16). The linearly increasing rate of denitrification with time at the NEC site is matched with an exponentially increasing headspace concentration (fig. 16). The reason for the substantially higher denitrification rates under the relatively low $\mathrm{NO}_{3}$ addition rate compared with the denitrification rates at higher $\mathrm{NO}_{3}$ addition levels is not known. It may be related to variation in marsh soil properties even within this relatively small area of uniform marsh vegetation, or it may be related to the fact that high $\mathrm{NO}_{3}$ concentrations can inhibit the denitrification pathway (to the $\mathrm{N}_{2} \mathrm{O}$ and $\mathrm{N}_{2}$ end products), possibly because of toxicity from an accumulation of $\mathrm{NO}_{2}$ (Glass and Silverstein, 1998).

At BHM sites, the time series illustrating the denitrification rate response to $\mathrm{NO}_{3}$ additions was more complicated than at NEC sites because of variations between the two sites studied as well as variations under different rates of $\mathrm{NO}_{3}$ addition with and without glucose. At the BHM GW4 site in July 2009, denitrification rates peaked between 4 hours and 30 minutes and 6 hours and 30 minutes after chamber sealing, 


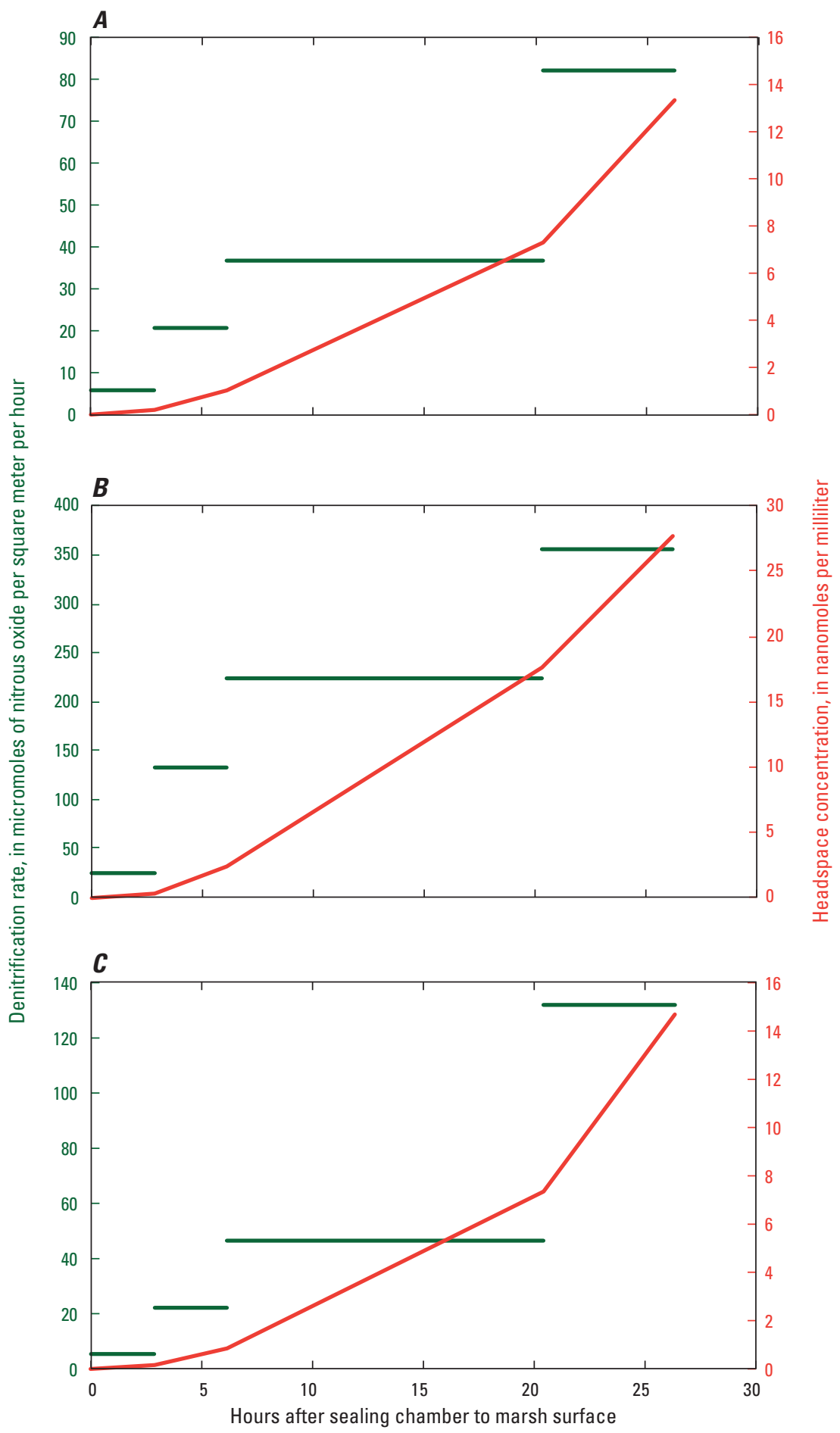

\author{
EXPLANATION

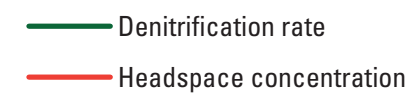

Figure 16. Relation between field denitrification rate and headspace nitrous oxide concentration and the varying incubation intervals once the chamber was sealed to the marsh surface at the Northeast Creek watershed site GW4 in September 2009, immediately following the following treatment additions: $A, 1.1$ grams of nitrogen per square meter only; $B, 1.1$ grams of nitrogen per square meter plus 3.6 grams of glucose per square meter; $C, 5.5$ grams of nitrogen per square meter only; $D, 5.5$ grams of nitrogen per square meter plus 3.6 grams of glucose per square meter; $E, 11$ grams of nitrogen per square meter; $F, 11$ grams of nitrogen per square meter plus 3.6 grams of glucose per square meter; $G, 22$ grams of nitrogen per square meter; $H, 22$ grams of nitrogen per square meter plus 3.6 grams of glucose per square meter; I, 55 grams of nitrogen per square meter; and $J, 55$ grams of nitrogen per square meter plus 3.6 grams of glucose per square meter. Horizontal bars on the $x$ axis show the period at which the denitrification rate begins to apply. The secondary y axis shows instantaneous concentrations of nitrous oxide in the headspace at the sampling times indicated. 


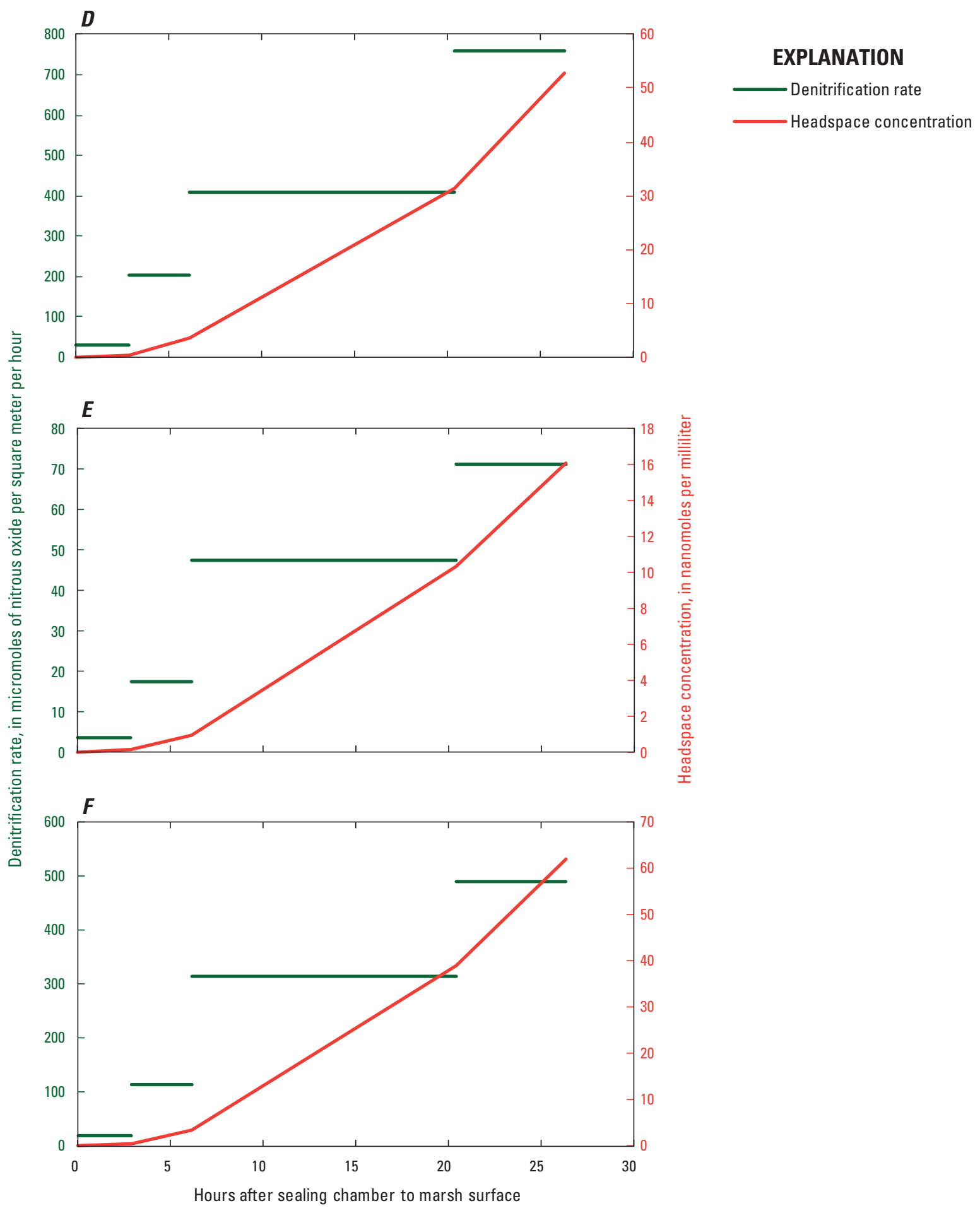

Figure 16.-Continued. 


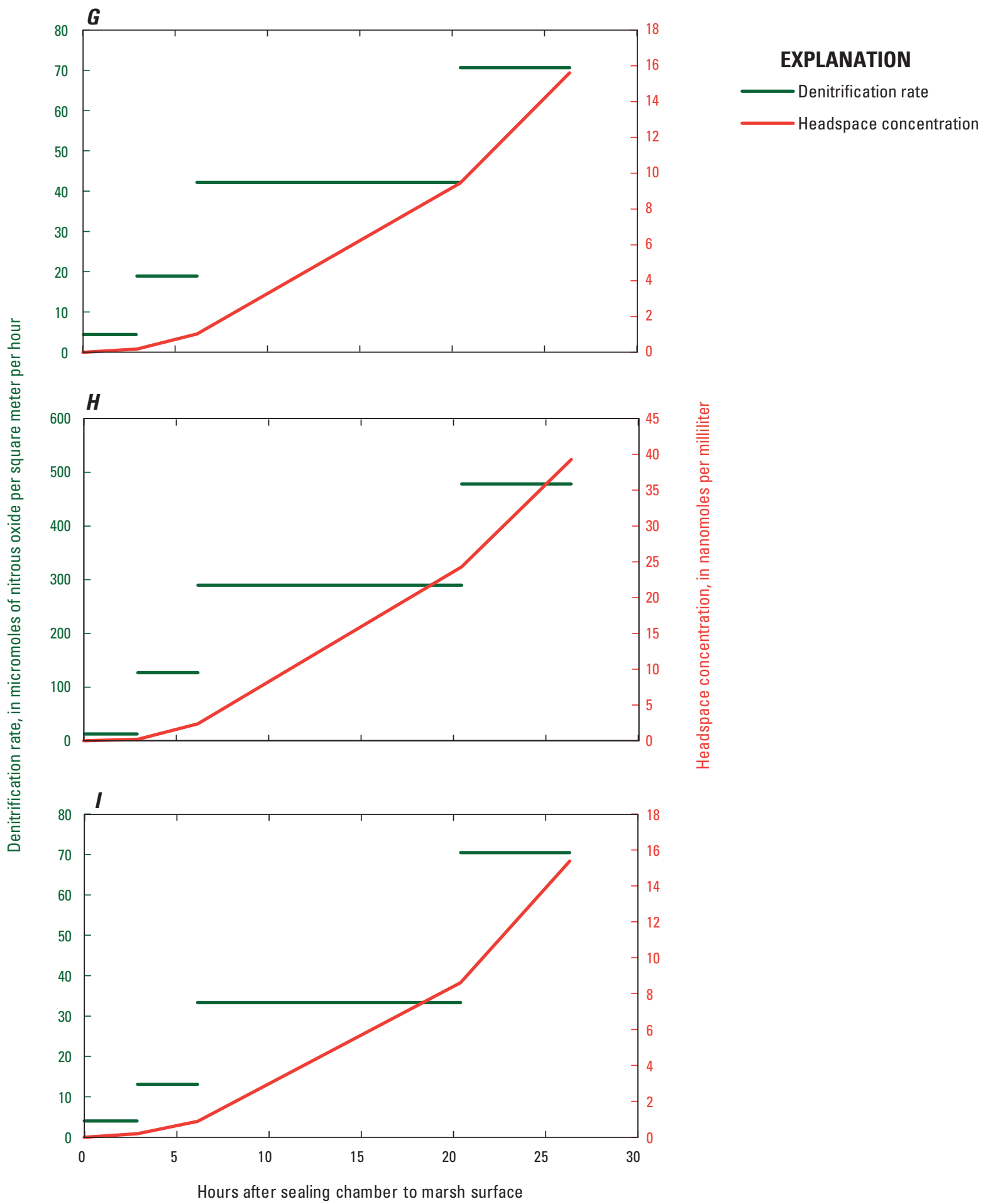

Figure 16.-Continued. 


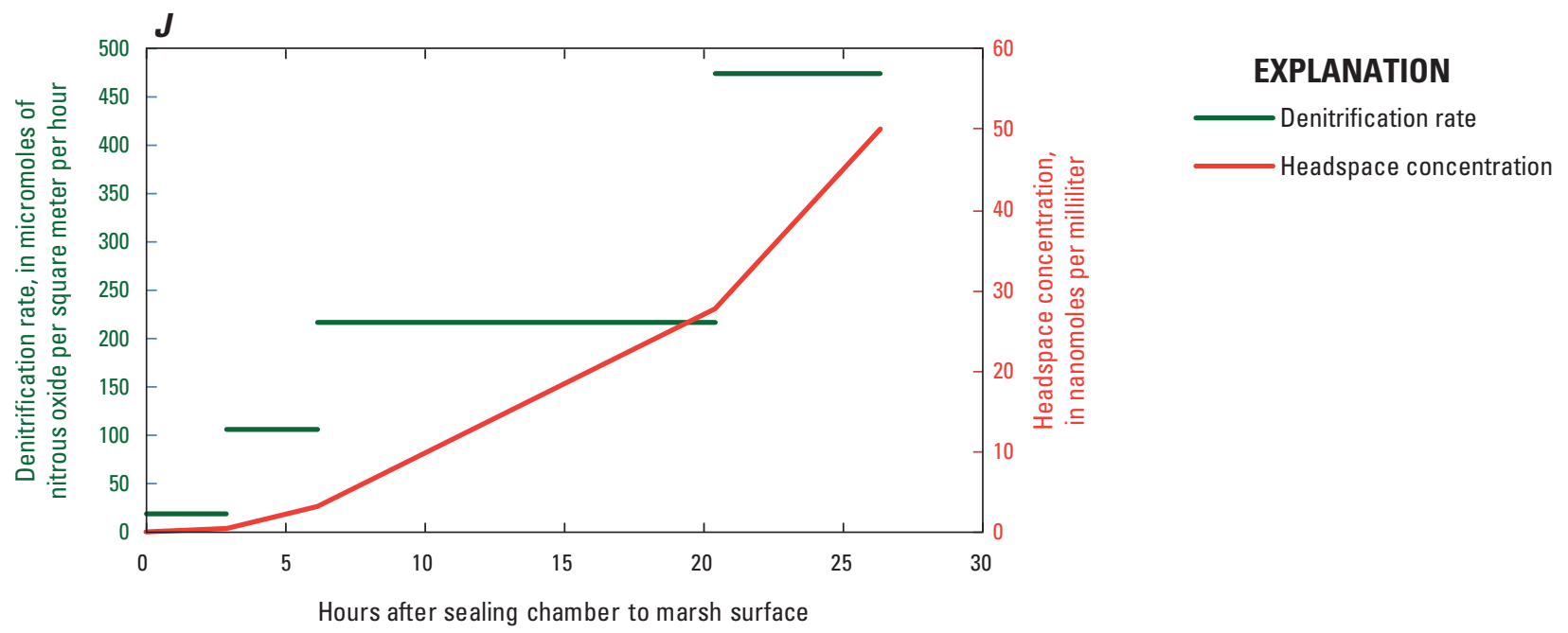

Figure 16.-Continued.

then declined substantially between 6 hours and 30 minutes and 22 hours, when the measurement period ended (fig. 17). The shapes of these curves were consistent with or without the addition of glucose. These initially increasing and subsequently decreasing rates with time were matched with headspace concentrations that follow a logistic or sigmoid curve implying diminishing availability of substrates during the measurement period (fig. 17). The fact that these curves were similar independently of the addition of glucose suggests that $\mathrm{NO}_{3}$ was the primary limiting substrate at this site and at this time. At the BHM GW5 site in August 2009, time series of the denitrification rate response were more variable, headspace concentrations increased quasilinearly over time, but the patterns of changes in $\mathrm{N}_{2} \mathrm{O}$ production rates over time were highly variable and not consistently related to glucose additions or to rates of $\mathrm{NO}_{3}$ addition (Huntington and others, 2011). The variable responses among sites and dates indicate that different factors probably limited denitrification rates under the distinctive set of conditions during those measurement periods.

On several measurement dates, glucose was added as a treatment without adding $\mathrm{NO}_{3}$ in order to determine whether denitrification in these marsh soils could be limited by the availability of a labile carbon substrate alone. In almost all cases, both at NEC and at BHM during June through September 2009, glucose additions resulted in an increase in measured denitrification. The increases ranged from factors of 1.05 to 15 , median 4.0 (table 6). The denitrification rates in these experiments with glucose-only additions were similar to most of the rates observed for the lowest levels of $\mathrm{NO}_{3}$ addition (table 5). However, the initial rates of denitrification with these glucose-only additions were not sustained beyond
3 to 4 hours after the chambers were sealed, compared with the rates at sites where $\mathrm{NO}_{3}$ alone or $\mathrm{NO}_{3}$ together with glucose were added. In the experiments during which $\mathrm{NO}_{3}$ or $\mathrm{NO}_{3}$ and glucose were added, denitrification rates either increased with time (NEC) or increased and then decreased but maintained a high rate compared with the ambient or glucose only experiments (BHM) (figs. 16 and 17). The data for these ambient and glucose- only experiments for sampling periods following the initial periods are reported in Huntington and others (2011). The glucose-induced enhancement of denitrification indicates the availability of a modest amount of $\mathrm{NO}_{3}$ but a lack of labile carbon.

The maximum denitrification rates observed during 2008 and 2009 for NEC and BHM for each site at which measurements were made following additions of $\mathrm{NO}_{3}$ or $\mathrm{NO}_{3}$ and glucose are shown in table 5. For most sites in both watersheds, the maximum denitrification rates were in the range of about 75 to $680 \mu \mathrm{mol} \mathrm{N}_{2} \mathrm{O}$ per square meter per hour $\left(\mathrm{m}^{-2} \mathrm{hr}^{-1} ; 18\right.$ to 170 grams of nitrogen per square meter per year $\left.\left(\mathrm{g} \mathrm{N} \mathrm{m}^{-2} \mathrm{yr}^{-1}\right)\right)$. The maximum rates were higher for the higher rates of nitrogen addition, and they were highest at sites where glucose was also added. These rates are higher than the maximum reported for salt marshes under ambient conditions even under very high ambient $\mathrm{NO}_{3}$ conditions (Tobias and Neubauer, 2009), indicating that these marsh soils are capable of denitrifying high rates of nitrogen additions, at least one to two orders of magnitude higher than that to which they are apparently exposed under ambient conditions. Tobias and Neubauer (2009) reported results from several studies using several different methods than the methods we used so the methods are not directly comparable and therefore comparisons between the rates they reported and 


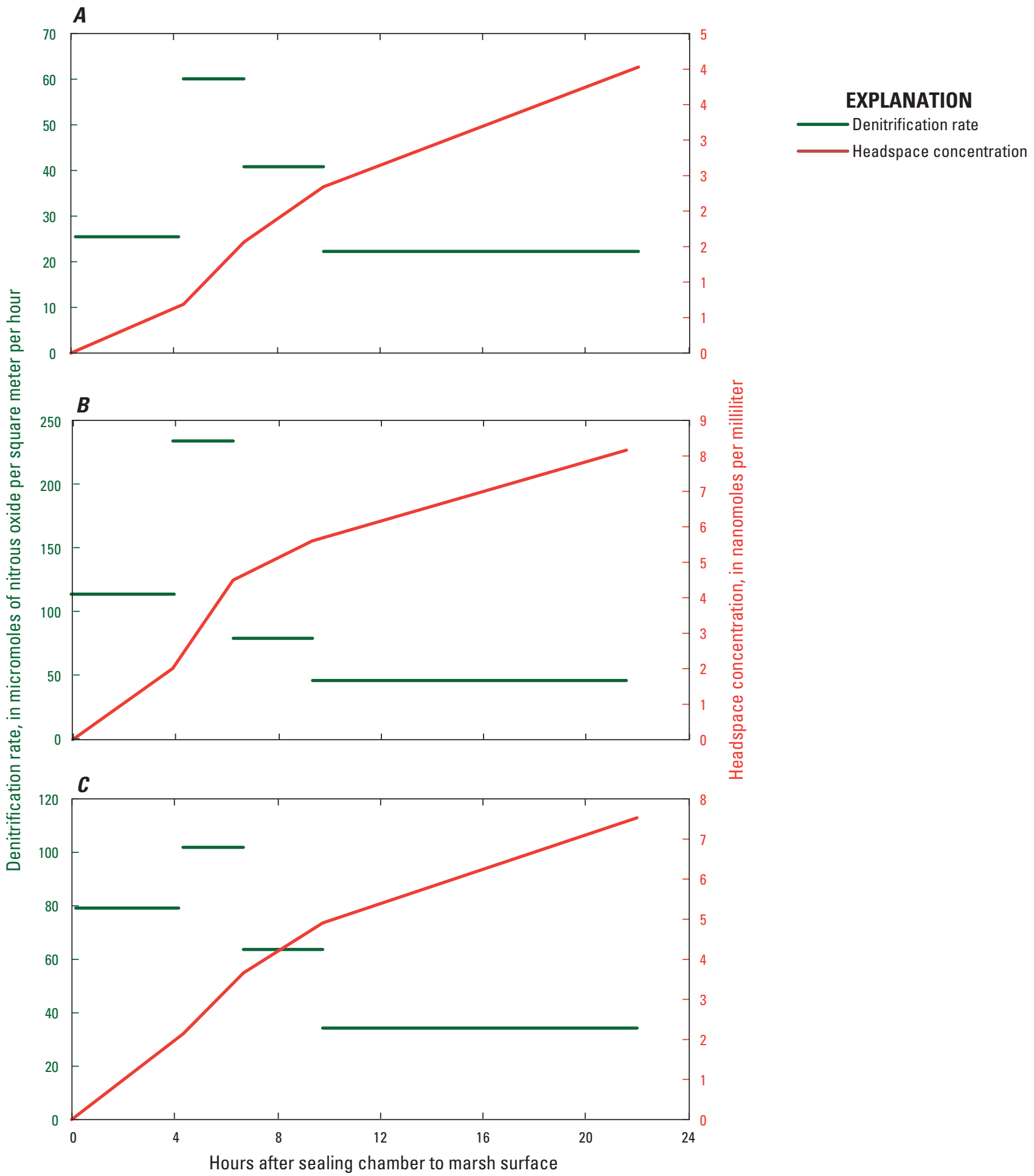

Figure 17. Relation between field denitrification rate and headspace nitrous oxide concentration and the varying incubation intervals once the chamber was sealed to the marsh surface at the Bass Harbor Marsh watershed site GW4 in September 2009, immediately following the following treatment additions: $A, 1.1$ grams of nitrogen per square meter only; $B, 1.1$ grams of nitrogen per square meter plus 3.6 grams of glucose per square meter; $C, 5.5$ grams of nitrogen per square meter only; $D, 5.5$ grams of nitrogen per square meter plus 3.6 grams of glucose per square meter; $E, 11$ grams of nitrogen per square meter; $F, 11$ grams of nitrogen per square meter plus 3.6 grams of glucose per square meter; $G, 22$ grams of nitrogen per square meter; $H, 22$ grams of nitrogen per square meter plus 3.6 grams of glucose per square meter; I, 55 grams of nitrogen per square meter; J, 55 grams of nitrogen per square meter plus 3.6 grams of glucose per square meter; $K, 110$ grams of nitrogen per square meter; and $L, 110$ grams of nitrogen per square meter plus 3.6 grams of glucose per square meter. Horizontal bars on the $x$ axis show the period at which the denitrification rate begins to apply. The secondary y axis shows instantaneous concentrations of nitrous oxide in the headspace at the sampling times indicated. 


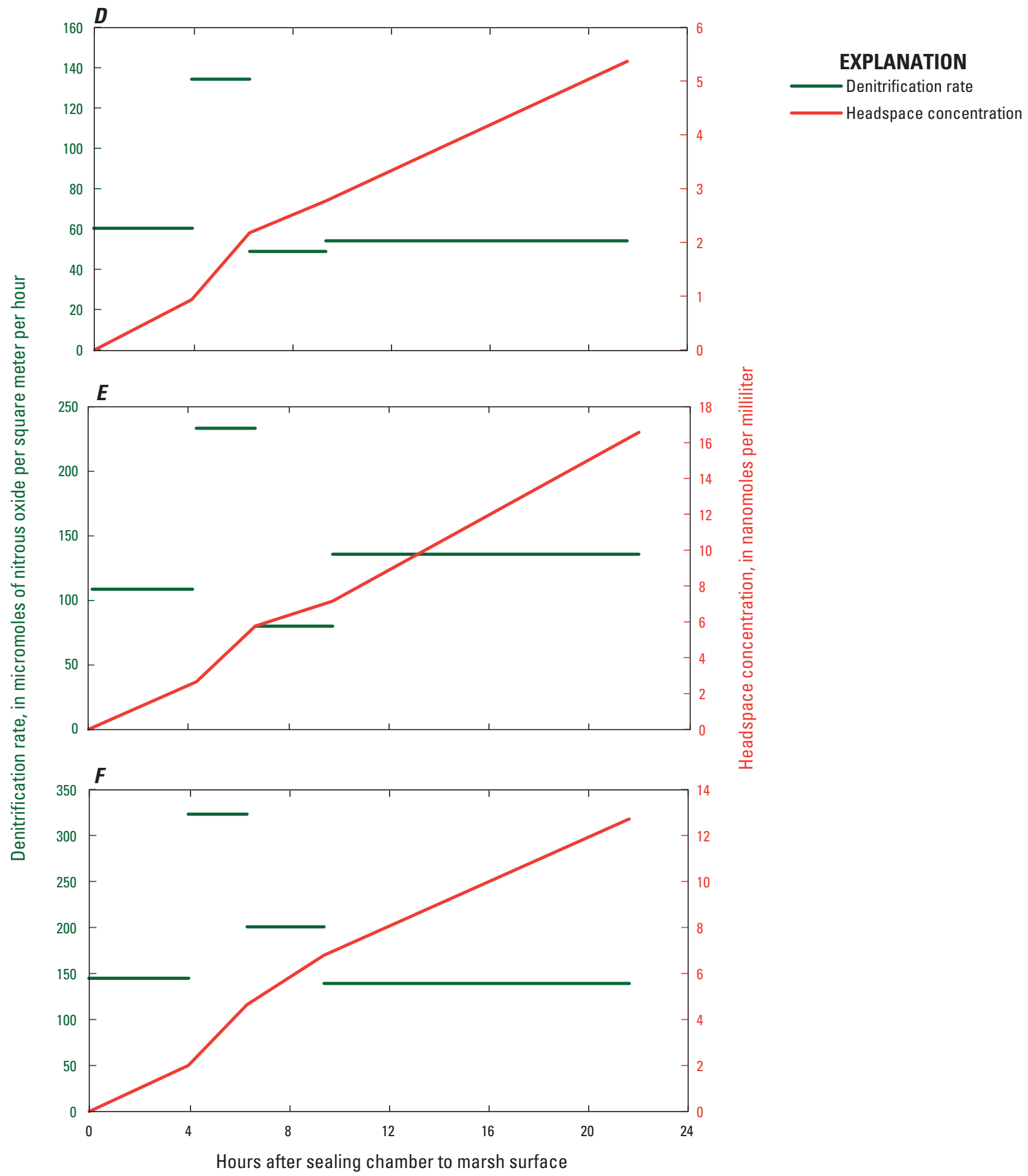

Figure 17.-Continued. 


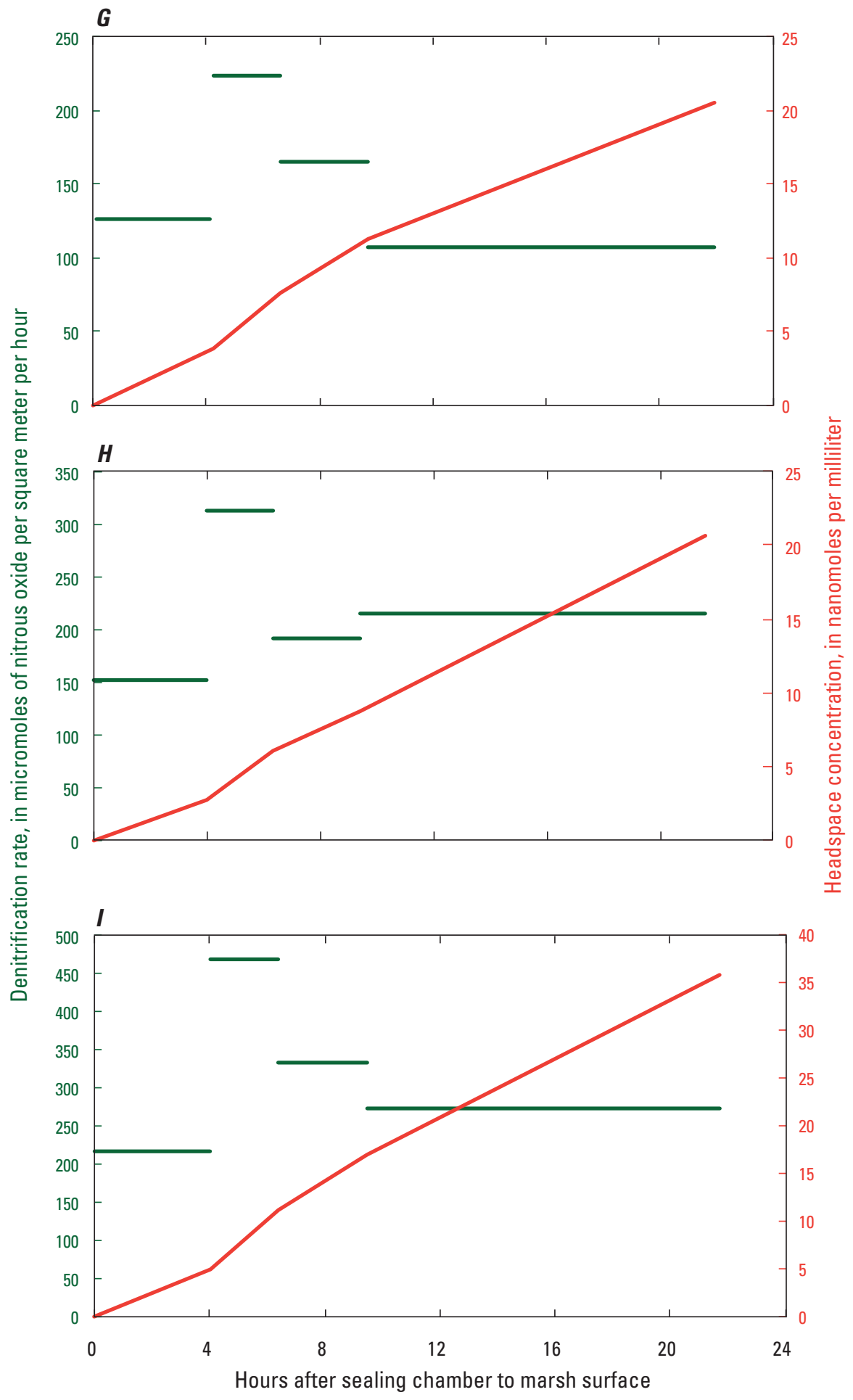

\section{EXPLANATION \\ Denitrification rate \\ Headspace concentration}

Figure 17.-Continued. 


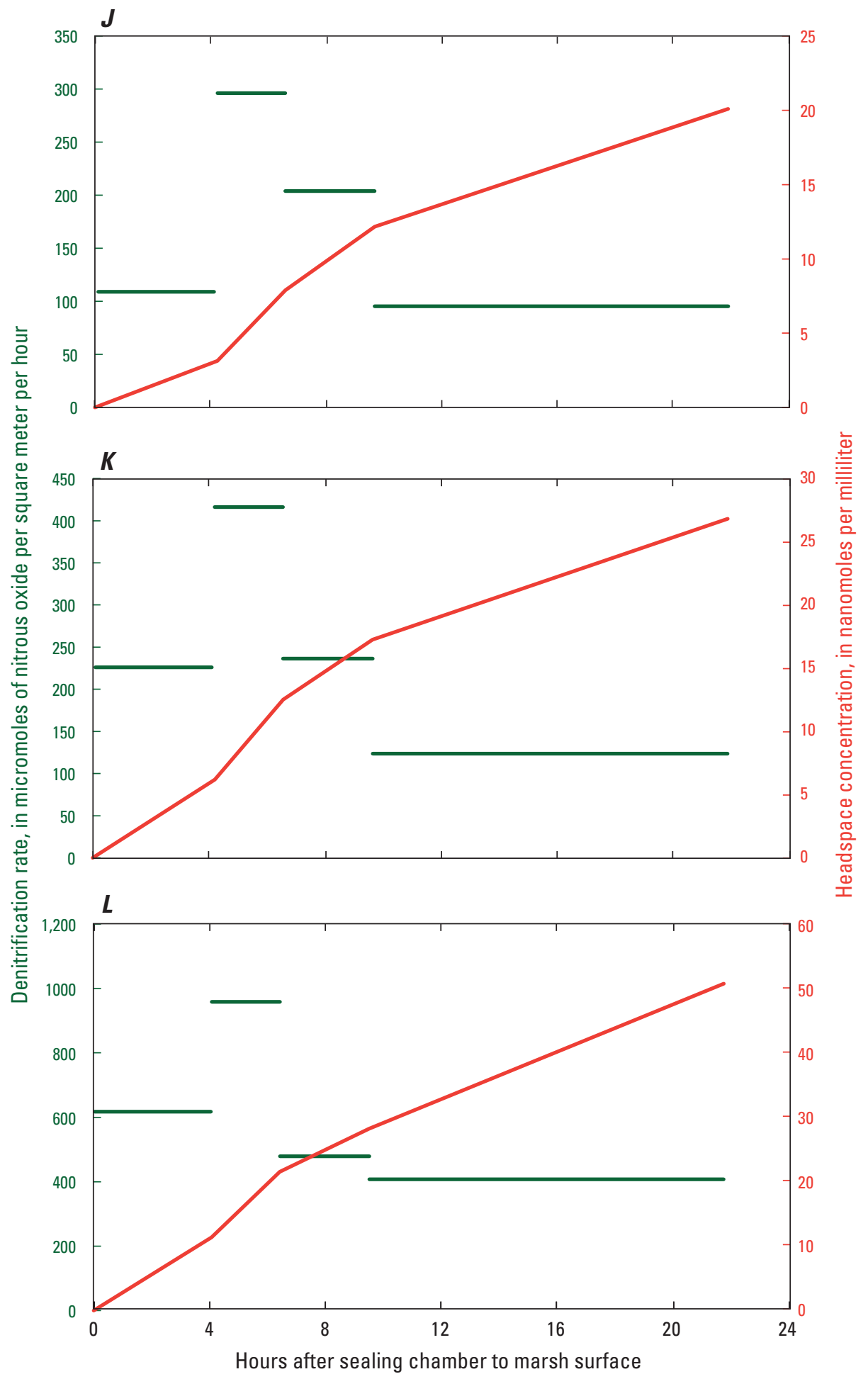

Denitrification rate

Headspace concentration

Figure 17.-Continued. 
Table 6. Denitrification rates in paired measurements under ambient or glucose only addition.

[Glucose-only addition was at 213 grams of glucose per cubic meter. $\mathrm{T}_{0}$ corresponds to the time of chamber sealing]

\begin{tabular}{|c|c|c|c|c|c|c|}
\hline \multicolumn{2}{|c|}{ Start time } & \multirow{2}{*}{$\begin{array}{l}\text { End time } \\
\qquad \mathrm{T}_{1}\end{array}$} & \multirow{2}{*}{$\begin{array}{l}\text { Ambient denitrification } \\
\qquad\left(\mu \mathrm{mol} \mathrm{N} \mathbf{N}_{2} \mathrm{~m}^{-2} \mathrm{hr}^{-1}\right)\end{array}$} & \multirow{2}{*}{$\begin{array}{l}\text { Start time } \\
\mathrm{T}_{0}\end{array}$} & \multirow{2}{*}{$\begin{array}{l}\text { End time } \\
\quad \mathrm{T}_{1}\end{array}$} & \multirow{2}{*}{$\begin{array}{l}75 \mathrm{mM} \text { glucose denitrification } \\
\left(\mu \mathrm{mol} \mathrm{N}_{2} \mathrm{O} \mathrm{m}^{-2} \mathrm{hr}^{-1}\right)\end{array}$} \\
\hline Location & $\mathrm{T}_{0}$ & & & & & \\
\hline BHM GW2 & 6/15/09 12:21 & 6/15/09 15:40 & 8.60 & 6/17/09 10:32 & 6/17/09 13:23 & 9.01 \\
\hline BHM GW3 & 6/15/09 12:41 & 6/15/09 15:48 & 25.5 & 6/16/09 16:27 & 6/16/09 20:03 & 135 \\
\hline NEC GW1 & 7/16/09 9:15 & $7 / 16 / 09$ 12:53 & 8.38 & 7/16/09 9:15 & $7 / 16 / 09$ 12:52 & 33.3 \\
\hline NEC GW2 & 7/16/09 9:40 & 7/16/09 13:02 & 7.85 & 7/16/09 9:40 & 7/16/09 13:01 & 59.3 \\
\hline NEC GW3 & 7/16/09 9:10 & $7 / 16 / 09$ 12:56 & 24.4 & 7/16/09 9:10 & 7/16/09 12:55 & 57.9 \\
\hline NEC GW4 & $7 / 16 / 09$ 9:25 & 7/16/09 12:59 & 11.9 & 7/16/09 9:25 & 7/16/09 12:58 & 181 \\
\hline NEC GW5 & 7/16/09 9:11 & 7/16/09 13:16 & 12.3 & 7/16/09 9:14 & 7/16/09 13:15 & 74.4 \\
\hline NEC GW6 & 7/16/09 10:02 & 7/16/09 13:05 & 13.1 & 7/16/09 10:03 & 7/16/09 13:04 & 56.2 \\
\hline BHM GW1 & 8/25/09 11:16 & 8/25/09 15:25 & 27.2 & 8/25/09 11:16 & 8/25/09 15:24 & 73.0 \\
\hline BHM GW2 & 8/25/09 11:13 & $8 / 25 / 09$ 15:22 & 12.6 & 8/25/09 11:14 & $8 / 25 / 09$ 15:21 & 1.61 \\
\hline BHM GW3 & 8/25/09 11:10 & 8/25/09 15:19 & 7.39 & 8/25/09 11:11 & 8/25/09 15:18 & 65.9 \\
\hline BHM GW4 & 8/25/09 11:07 & 8/25/09 15:16 & 19.0 & 8/25/09 11:08 & 8/25/09 15:15 & 52.2 \\
\hline BHM GW5 & 8/25/09 11:04 & 8/25/09 15:09 & 15.1 & 8/25/09 11:05 & 8/25/09 15:08 & 46.2 \\
\hline BHM GW6 & 8/25/09 11:01 & 8/25/09 15:04 & 12.3 & 8/25/09 11:02 & 8/25/09 15:03 & 60.1 \\
\hline NEC GW2 & 9/21/09 16:12 & 9/21/09 18:01 & 14.0 & 9/21/09 16:12 & 9/21/09 18:00 & 11.8 \\
\hline NEC GW3 & 9/21/09 15:52 & 9/21/09 18:11 & 18.1 & 9/21/09 15:52 & 9/21/09 18:10 & 38.4 \\
\hline NEC GW4 & 9/21/09 16:05 & 9/21/09 18:21 & 14.0 & 9/21/09 16:05 & 9/21/09 18:20 & 43.8 \\
\hline NEC GW5 & 9/21/09 15:00 & 9/21/09 18:17 & 9.65 & 9/21/09 15:00 & 9/21/09 18:16 & 114 \\
\hline NEC GW6 & 9/21/09 15:35 & 9/21/09 18:31 & 14.1 & 9/21/09 15:35 & 9/21/09 18:30 & 38.1 \\
\hline
\end{tabular}

what we measured should be made cautiously. Nielsen (2002a) estimated that, for an 18-month period beginning April 1999, the NEC estuary received 5,900 kilograms (kg) $\mathrm{N}$ in tributary inputs. If that mass of nitrogen were to be distributed on the $1.85-\mathrm{km}^{2}$ Fresh Meadow Marsh fringing the NEC estuary, it would be equivalent to an input of $2.1 \mathrm{~g} \mathrm{~N} \mathrm{~m}^{-2} \mathrm{yr}^{-1}$. Groundwater inputs to NEC and BHM have not been quantified, but, on the basis of estimates from Nielsen (2002b), a similar amount of nitrogen $\left(2.2 \mathrm{~g} \mathrm{~N} \mathrm{~m}^{-2} \mathrm{yr}^{-1}\right)$ may have been released during 2001 from the septic systems of the estimated 279 residences in the combined drainage basins of Aunt Betseys Creek, French Hill Brook, Old Mill Brook, and Stony Book that drain into NEC. Denitrification in the uplands along the flowpaths from septic systems to the fringing marsh and estuary probably removes a substantial fraction of this estimated nitrogen input (Ritter and Eastburn, 1988). Similarly, tidal nitrogen inputs have not been quantified for NEC, but a preliminary estimate for BHM indicated that, in that estuary, tidal inputs could be comparable to surface water inputs (Doering and others (1995). Because bedrock sills restrict tidal inflow in both estuaries, tidal inputs (flood tide) are limited to substantially less than half that of the tidal period. Rising sea level, however, is increasing inputs and the residence time of tidal inputs. The denitrification capacity of the marsh soils in NEC and BHM (table 5) is clearly greater than the potential combined inputs of nitrogen by surface water and groundwater.

\section{Field Denitrification Rate in Relation to Environmental Variables}

Correlation analyses were performed to relate in-place denitrification rates to several measured variables. The denitrification rates selected for this analysis were those observed for the lowest rates of $\mathrm{NO}_{3}$ additions because the measured denitrification rates under ambient conditions were very low. Unfortunately the long-term inundation of the NEC soils limited the number of occasions that we could undertake comparable experiments on these sites and, in BHM, we had no measurements until September 2008. For NEC the lowest $\mathrm{NO}_{3}$ addition rate was $1.1 \mathrm{~g} \mathrm{~N} \mathrm{~m}^{-2}$; for BHM the lowest $\mathrm{NO}_{3}$ addition rate was usually 3.3 to $5.5 \mathrm{~g} \mathrm{~N} \mathrm{~m}^{-2}$ in 6 cases and $22 \mathrm{~g} \mathrm{~N} \mathrm{~m}^{-2}$ in one case. The data used in this analysis are reported in Huntington and others (2011). 
A positive statistically significant $(\mathrm{p}<0.050)$ correlation was observed between denitrification rate and soil temperature (table 7). A positive correlation was expected between soil temperature and denitrification, based on previous investigations. There was a weak, but not statistically significant $(\mathrm{p}>0.05)$, negative correlation between denitrification rate and water level in the marsh soils. When the water table was closer to the surface, the thickness of the oxic/anoxic interface may have been restricted or raised into a zone where $\mathrm{NO}_{3}$ was less available. Such changes in the thickness or relative position of the oxic/anoxic interface could explain a tendency towards lower denitrification rate with higher water levels. There were no significant relationships between denitrification rate and concentrations of ammonium, $\mathrm{NO}_{3}$ and $\mathrm{NO}_{2}$, total dissolved nitrogen, or dissolved oxygen in groundwater. The generally weak, or lack of, correlations probably reflects differences in marsh soil properties that we did not measure such as the chemical properties at the oxic/anoxic interface or the thickness of the zone at which denitrification occurred.

The tidal level recorded at Bar Harbor, Maine, at the midpoint of the in-place denitrification rate during the measurement period in the field was weakly but not significantly $(p>0.05)$ negatively correlated with the denitrification rate (table 7). The water level in NEC did not respond directly to tidal influences; instead, it was most responsive to surfacewater runoff (fig. 9A). The water level in BHM was not recorded continuously but was observed to respond directly to the diurnal variation in tide level. The marsh surface at BHM would flood regularly for a brief period around high tide during most days in the approximately 2 -week period between consecutive neap tides.

Table 7. Pearson correlation coefficients between denitrification rate and the noted variables under experimental conditions where low levels of nitrate were added and no glucose was added.

\begin{tabular}{|c|c|c|}
\hline Variable & $\begin{array}{c}\text { Pearson correlation } \\
\text { coefficients }\end{array}$ & p-value \\
\hline Soil organic matter fraction & 0.065 & 0.781 \\
\hline Soil temperature & 0.439 & 0.046 \\
\hline Water level & -0.407 & 0.067 \\
\hline GW ammonia & 0.234 & 0.321 \\
\hline GW nitrate plus nitrite & -0.166 & 0.486 \\
\hline GW total dissolved nitrogen & 0.151 & 0.525 \\
\hline GW specific conductance & -0.346 & 0.135 \\
\hline GW temperature & 0.034 & 0.895 \\
\hline GW dissolved oxygen & 0.130 & 0.632 \\
\hline Bar Harbor tide elevation ${ }^{1}$ & -0.377 & 0.091 \\
\hline
\end{tabular}

${ }^{1}$ Bar Harbor, Maine, tide level at midpoint during the in situ field denitrification measurement period.

\section{Tributary Water Quality}

Water-quality data for all tributaries to NEC and BHM estuaries were presented for all samples collected for this study and are reported in Huntington and others (2011). Periodic monitoring of water quality in these tributaries is important for assessing changes in water quality as a result of ongoing changes in land use within these watersheds (for example, Nielsen and Kahl, 2007). Residential development outside the park boundary has increased rapidly in recent years. For example, during 1981 to 2001 the number of residences in the combined drainage basins of Aunt Betseys Creek, French Hill Brook, Old Mill Brook, and Stony Book in the Northeast Creek (NEC) watershed increased from 83 to 279 (Nielsen, 2002a,b). This increase in residential development may have increased nitrogen inputs to the NEC estuary and could have increased nutrient concentrations in the tributaries draining into the estuaries. However, the concentration of nitrogen species determined on multiple samples collected during 2008 and 2009 for this study does not indicate an increase in concentration compared with previous studies for samples collected during 1990 to 1992 (Doering and others, 1995) or in 1999 and 2000 (table 8; Nielsen and Kahl, 2007). The fate of nitrogen inputs in these watersheds, that is presumed to be increasing due to the increasing numbers of households and septic system effluents, is not known. Denitrification in uplands or along groundwater flowpaths may remove most of the nitrogen before it reaches the tributaries. Alternatively, septic-derived nitrogen may follow flowpaths that lead directly to groundwater seepage into the estuaries themselves. Alternatively, again, it is possible that nitrogen derived from increases in households has generally not yet arrived at the estuary because of long and circuitous pathways and sorption along flowpaths. Groundwater seepage into NEC and BHM estuaries has been suggested in an earlier study that used aerial thermal imagery (Culbertson and others, 2007).

\section{Denitrification Potential of Marsh Soils at Acadia National Park}

Denitrification requires $\mathrm{NO}_{3}$, suboxic (but not anoxic) conditions, and organic substrates (electron donors) for heterotrophic bacteria (Seitzinger and others, 2006). The marshes fringing estuaries where marsh soils are high in organic matter and subject to variable water levels due to strong tidal forcing (as at BHM), or subject to much weaker tidal forcing and periodic surface freshwater flooding (as at NEC) meet two of the three criteria. The question at Acadia concerns whether the first criterion, availability of $\mathrm{NO}_{3}$, is met. Given the eutrophic state of the BHM estuary, the fringing marsh soils in that estuary would probably have higher rates of denitrification under ambient conditions than would the marsh soils in the comparatively unimpacted NEC marshes. That the rates of denitrification in BHM and NEC under ambient conditions 
Table 8. Mean and standard errors of nutrient concentrations in tributaries to Northeast Creek and Bass Harbor Marsh.

[Concentrations are from samples during this study (2008 to 2009, number of samples $(n)=6$ to 11$)$ and as reported in previous studies (1999 to 2009 , $n=20$ : Nielsen, 2002a; Nielsen and Kahl, 2007; and 1990 to 1992, n=6: Doering and others, 1995. For some analyses, nitrate or $\mathrm{NH}_{4}$ concentrations were reported as " $<$ the laboratory minimum reporting limit $(\mathrm{mrl})$ ", in these cases values of half the mrl were used in the calculation of the mean values. $\mathrm{mg} / \mathrm{L}, \mathrm{milligrams}$ per liter; $\mathrm{N}$, nitrogen; nitrate, nitrate; $\mathrm{NH}_{4}$, ammonium; --, no data; <, less than]

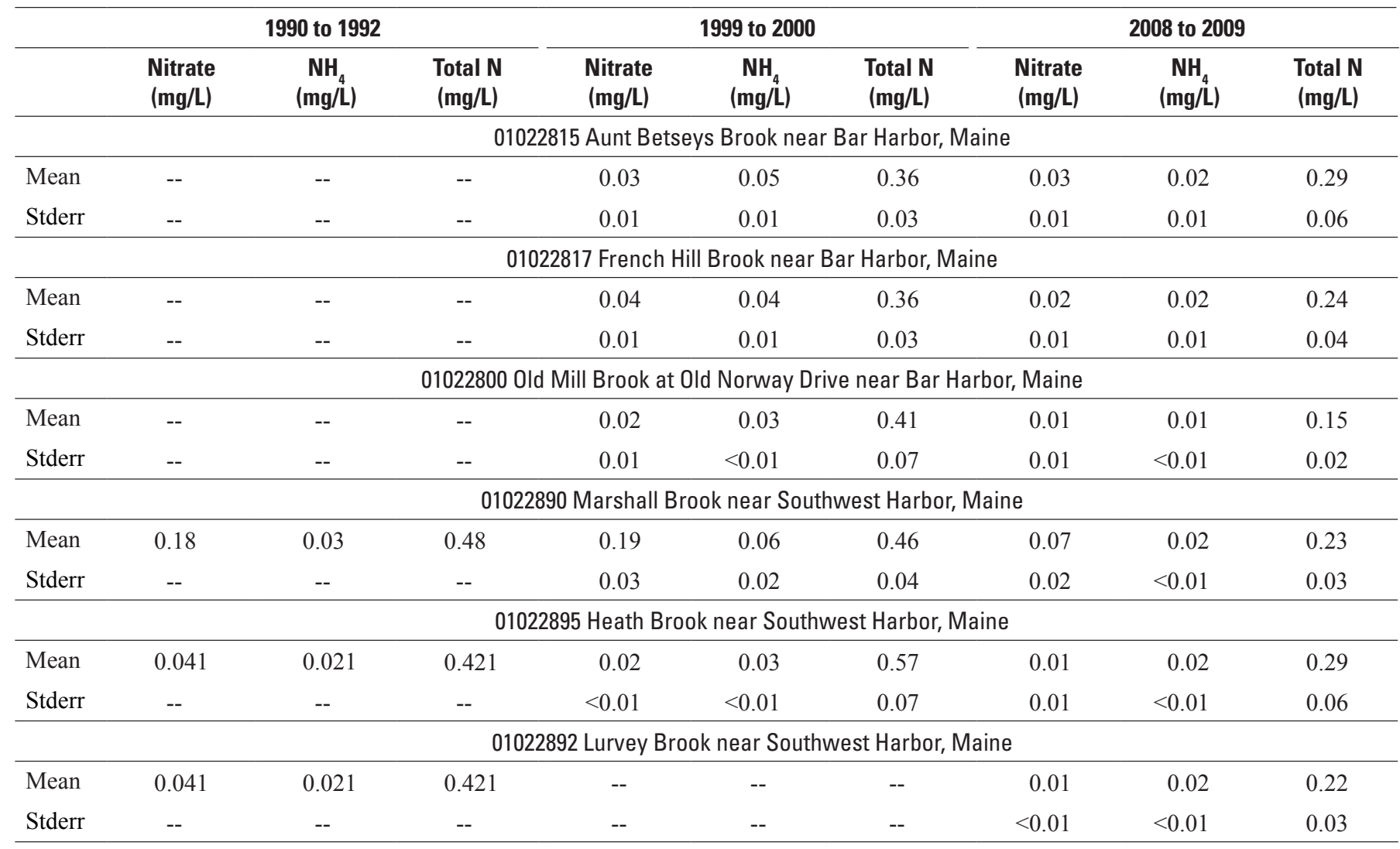

${ }^{1}$ Doering and others (1995) sampled downstream of the confluence of Lurvey and Heath Brooks so that these values are not directly comparable to those reported for these tributaries that were sampled separately upstream of their confluence in this study, but are shown here for relative comparison.

measured throughout two consecutive growing seasons are similarly relatively low indicates that $\mathrm{NO}_{3}$ availability is relatively low in both marsh systems. It is evident from the addition of $\mathrm{NO}_{3}$ together with glucose that these marsh soils are capable of comparatively high rates of denitrification (Tobias and Neubauer, 2009). The observed estuarine eutrophication in BHM is therefore not a result of nitrogen inputs to marsh soils that exceed the denitrification capacity in these systems. To the extent that eutrophication and nuisance algal blooms may be a result of nutrient enrichment derived from human activities in the watersheds and from elevated atmospheric deposition of nitrogen, it is more probable that these inputs do not interact with marsh soils through surface runoff, flooding, or shallow groundwater seepage into the marsh soils. If these terrestrial inputs to the estuary are the cause of the observed eutrophic condition in BHM, they must bypass the marsh in channelized surface flow or they must circumvent the marsh in shallow groundwater seepage along subsurface pathways that enter the estuary directly. Taken together, these observations of estuarine eutrophication in BHM, in spite of low rates of denitrification under ambient conditions and high denitrification capacity, are consistent with a conceptual model whereby nitrogen derived from terrestrial inputs probably bypasses the marsh soils (Tobias and Neubauer, 2009).

\section{Conclusions}

Denitrification measurements in marsh soils fringing the estuaries at Bass Harbor Marsh and Northeast Creek at Acadia National Park indicated that, under ambient conditions, denitrification rates were low in both marshes. The low denitrification rates, in spite of substantial evidence for eutrophication as demonstrated by extensive nuisance algal blooms in the Bass Harbor Marsh estuary, indicated that these marsh soils probably do not receive large inputs of nitrogen from the 
surrounding terrestrial landscape. The relatively high rates of denitrification observed following the addition of nitrate indicate that these soils have the capacity to denitrify substantially more nitrogen than they currently receive. In most cases, the addition of glucose plus nitrate resulted in higher rates of denitrification than the addition of nitrate alone. The results of this study indicate that limited denitrification capacity of fringing marsh soils can be ruled out as a cause to explain eutrophication in these estuaries.

\section{Acknowledgments}

The authors are grateful for the support they received from several people that contributed to the successful completion of this study. Staff at Acadia National Park (David Manski and Bill Gawley) helped facilitate this study from the initial conceptualization through its completion. Staff at the U.S. Geological Survey, Maine Water Science Center (James Caldwell, Charles Schalk, Laura Flight, and Greg Stewart) provided assistance with groundwater level data processing and interpretation, overall data review, and data uploading into the Survey's National Water Information System database. Jeffrey Barbaro, Richard Smith, and Leslie DeSimone, all with the U.S. Geological Survey, provided technical reviews that improved the report.

\section{References Cited}

Aelion, C.M., and Shaw, J.N., 2000, Denitrification in South Carolina (USA) Coastal Plain aquatic sediments: Journal of Environmental Quality, v. 29, p. 1696-1702.

American Public Health Association, 1998, Standard methods for the examination of water and wastewater (20th ed.): Washington, D.C., American Public Health Association.

American Society of Testing and Materials International, 2012, ASTM D887-08-Standard practices for sampling water-formed deposits: American Society of Testing and Materials International, 8 p.

Bricker, S., Clement, C.G., Pirhalla, D.E., Orlando, S.P., and Farrow, D.R.G., 1999, National estuarine eutrophication assessment of nutrient enrichment in the Nation's estuaries: Silver Spring, Md., National Oceanic and Atmospheric Administration, $71 \mathrm{p}$.

Burke, D.J., Hamerlynck, E.P., and Hahn, D., 2002, Interactions among plant species and microorganisms in salt marsh sediments: Applied and Environmental Microbiology, v. 68, no. 3, p. 1157-1164.
Calhoun, A.J.K., Cormier, J.E., Owen, R.B.J., Roman, C.T., and Tiner, R.W.J., 1994, The wetlands of Acadia National Park and vicinity: Maine Agriculture and Forest Experiment Station Miscellaneous Report Publication 721, Orono, University of Maine, 108 p.

Cloern, J.E., 2001, Our evolving conceptual model of the coastal eutrophication problem: Marine Ecology Progress Series, v. 210, p. 223-253.

Culbertson, C.W., Huntington, T.G., and Caldwell, J.M., 2007, Nutrient enrichment in estuaries from discharge of shallow ground water, Mount Desert Island, Maine: U.S. Geological Survey Scientific Investigations Report 2007-5188, 34 p.

Davidson, E.A., and Kingerlee, W., 1997, A global inventory of nitric oxide emissions from soils: Nutrient Cycling in Agroecosystems, v. 48, p. 37-50.

Davies, B.E., 1974, Loss-on-ignition as an estimate of soil organic matter: Soil Science Society of America Proceedings, v. 38, p. 150-151.

Day, J.W., Jr., Hall, C.A.S., Kemp, W.M., and YanezArancibia, A., 1989, Estuarine ecology: New York, N.Y., Wiley, 558 p.

D’Elia, C.F., Stuedler, P.A., and Corwin, N., 1977, Determination of total nitrogen in aqueous sampling using persulfate digestion: Limnology and Oceanography, v. 22, p. 760-764.

Doering, P.H., Roman, C.T., Beatty, L.L., Keller, A.A., and Oviatt, C.A., 1995, Water quality and habitat evaluation of Bass Harbor Marsh, Acadia National Park, Maine: National Park Service Technical Report NPS/NESORNR/NRTR/ 95-31, 148 p., plus appendix.

Duff, J.H., Pringle, C.M., and Tiska, F.J., 1996, Nitrate reduction in sediments of lowland tropical streams draining swamp forest in Costa Rica-An ecosystem perspective: Biogeochemistry, v. 33, p. 179-196.

Farris, C.N., and Oviatt, C.A., 1999, Changes in metabolic rates under fluctuating salinity regimes for two subtidal estuarine habitats: Estuaries, v. 22, p. 126-137.

Fitch, Rosemarie, Theodose, Theresa, and Dionne, Michele, 2009, Relationships among upland development, nitrogen, and plant community composition in a Maine salt marsh: Wetlands, v. 29, no. 4, p. 1179-1188.

Francis, C.W., and Mankin, J.B., 1977, High nitrate denitrification in continuous flow-stirred reactors: Water Research, v. 11, no. 3, p. 289-294.

Gilbert, T.W., Behymer, T.D., and Castañeda, H.B., 1982, Determination of dissolved oxygen in natural and wastewaters: American Laboratory, v. 14, no. 3, p. 119-134. 
Glass, C., and Silverstein, J., 1998, Denitrification kinetics of high nitrate concentration water - $\mathrm{pH}$ effect on inhibition and nitrite accumulation: Water Research, v. 32, no. 3, p. 831-839.

Greene, S., 2005, Measurements of denitrification in aquatic ecosystems; Literature review and data report: Solomons, Md., University of Maryland Center for Environmental Science Technical Report Series [UMCES] CBL 05-094, 29 p.

Groffman, P.M., Altabet, M.A., Böhlke, J.K., Butterbach-Bahl, K., David, M.B., Firestone, M.K., Giblin, A.E., Kana, T.M., Nielsen, L.P., and Voytek, M.A., 2006, Methods for measuring denitrification-Diverse approaches to a difficult problem: Ecological Applications, v. 16, no. 6, p. 2091-2122.

Harvey, J.W., and Odum, W.E., 1990, The influence of tidal marshes on upland groundwater discharge to estuaries: Biogeochemistry, v. 10, p. 217-236.

Herbert, R.A., 1999, Nitrogen cycling in coastal marine ecosystems: [Federation of European Microbiological Societies] Microbiology Review, v. 23, p. 563-590.

Howes, B.L., Weiskel, P.K., Goehringer, D.D., and Teal, J.M., 1996, Interception of freshwater and nitrogen transport from uplands to coastal waters-The role of saltmarshes, in Nordstrom, K.F., and Roman, C.T., eds., Estuarine shores-Hydrological, geomorphological and ecological interactions: Sussex, United Kingdom, Wiley Interscience, p. 287-310.

Huntington, T.G., Culbertson, C.W., and Duff, J.H., 2011, Denitrification rates in marsh soils and hydrologic and water quality data for Northeast Creek and Bass Harbor Marsh watersheds, Mount Desert Island, Maine: U.S. Geological Survey Open-File Report 2011-1252, 30 p., at http://pubs.usgs.gov/of/2011/1252/.

Huntington, T.G., Harden, J.W., Dabney, S.M., Marion, D.A., Alonso, C., Sharpe, J.M., and Fries, T.L., 1998, Soil, environmental, and watershed measurements in support of carbon cycling studies in northwestern Mississippi: U.S. Geological Survey Open-File Report 98-501, 91 p.

Jorgensen, K.S., and Sorenson, Jan, 1988, Two annual maxima of nitrate reduction and denitrification in estuarine sediments (Norsminde Fjord, Denmark): Marine Ecology Progress Series, v. 94, p. 267-274.

Kahl, J.S., Manski, D., Flora, M., and Houtman, N., eds., 2000, Water resources management plan, Acadia National Park, Mount Desert Island, Maine: National Park Service NPS D-209, April, 102 p.

Kinney, E.H., and Roman, C.T., 1998, Response of primary producers to nutrient enrichment in a shallow estuary: Marine Ecology Progress Series, v. 163, p. 89-98.

Knowles, R., 1982, Denitrification: Microbiological Reviews, v. 64 , no. 1, p. $43-70$.
Koch, M.S., Maltby, E., Oliver, G.A., and Bakker, S.A., 1992, Factors controlling denitrification rates of tidal mudflats and fringing salt marshes in southwest England: Estuarine, Coastal and Shelf Science, v. 34, no. 5, p. 471-485.

Lee, R.Y., Joye, S.B., Roberts, B.J., and Valiela, I., 1997, Release of $\mathrm{N}_{2}$ and $\mathrm{N}_{2} \mathrm{O}$ from salt-marsh sediments subject to different land-derived nitrogen loads: Biological Bulletin, v. 193 , no. 2, p. 292-293.

Lubinski, Sara, Hopp, Kevin, and Gawler, Susan, 2003, U.S. Geological Survey-National Park Service vegetation mapping program-Acadia National Park: U.S. Geological Survey, 50 p., plus appendixes, at http://biology.usgs.gov/ npsveg/acad/acadrpt.pdf.

Meding, S.M., Morris, L.A., Hoover, C.M., Nutter, W.L., and Cabrera, M.L., 2001, Denitrification at a long-term forested land treatment system in the Piedmont of Georgia: Journal of Environmental Quality, v. 30, p. 1411-1420.

Murphy, J., and Riley, J.P., 1962, A modified single solution method for determination of phosphate in natural waters: Analytica Chemica Acta, v. 27, p. 31-36.

National Research Council, 2000, Clean coastal watersUnderstanding and reducing the effects of nutrient pollution: Washington, D.C., National Academy Press, 428 p.

Nielsen, M.G., 2002a, Estimating quantity of water in fractured bedrock units on Mount Desert Island, and estimated ground-water use, recharge, and dilution of nitrogen in septic waste in the Bar Harbor area, Maine: U.S. Geological Survey Open-File Report 02-435, 45 p.

Nielsen, M.G., 2002b, Water budget for and nitrogen loads to Northeast Creek, Bar Harbor, Maine: U.S. Geological Survey Water-Resources Investigations Report 02-4000, 32 p.

Nielsen, M.G., Caldwell, J.M., Culbertson, C.W., and Handley, Michael, 2002, Hydrologic data collected in small watersheds on Mount Desert Island, Maine-1999-2000: U.S. Geological Survey Open-File Report 02-416, 47 p.

Nielsen, M.G., and Kahl, J.S., 2007, Nutrient export from watersheds on Mount Desert Island, Maine, as a function of land use and fire history: Environmental Monitoring and Assessment, v. 126, p. 81-96.

Oremland, R.S., Umberger, C., Culbertson, C.W., and Smith, R.L., 1984, Denitrification in San Francisco Bay intertidal sediments: Applied and Environmental Microbiology, v. 47, no. 5 , p. $1106-1112$.

Parton, W.J., Mosier, A.R., Ojima, D.S., Valentine, D.W., Schimel, D.S., Weier, K., and Kulmala, A.E., 1996, Generalized model for $\mathrm{N}_{2}$ and $\mathrm{N}_{2} \mathrm{O}$ production from nitrification and denitrification: Global Biogeochemical Cycles, v. 10, no. 3, p. 401-412. 
Patrick, W.H., and DeLaune, R.D., 1977, Chemical and biological redox systems affecting nutrient availability in coastal wetlands: Geoscience and Man, v. 18, p. 131-137.

Portnoy, J.W., Nowicki, B.L., Roman, C.T., and Urish, D.W., 1998, The discharge of nitrate-contaminated groundwater from developed shoreline to marsh-fringed estuary: Water Resources Research, v. 34, no. 11, p. 3095-3104.

Puckett, L.J., Cowdery, T.K., McMahon, P.B., Tornes, L.H., and Stoner, J.D., 2002, Using chemical, hydrologic, and age dating analysis to delineate redox processes and flow paths in the riparian zone of a glacial outwash aquiferstream system: Water Resources Research, v. 38, no. 8, doi:10.1029/2001R00396.

Reay, W.G., Gallagher, D.L., and Simmons, G.M.J., 1992, Groundwater discharge and its impact on surface water quality in a Chesapeake Bay inlet: Journal of the American Water Resources Association, v. 28, p. 1121-1134.

Ritter, W.F., and Eastburn, R.P., 1988, A review of denitrification in on-site wastewater treatment systems: Environmental Pollution, v. 51, no. 1, p. 49-61.

Roman, C.T., LaBash, Charles, Weber, Jill, and Rooney, Sally, 2001, Wetland and deepwater habitats, Northeast Creek (Mt. Desert Island, Maine): U.S. National Park Service Technical Report 2179258, 18 p., plus 1 map sheet.

Scheiner, Dora, 1976, Determination of ammonia and Kjeldahl nitrogen by indophenol method: Water Research, v. 10, p. 31-36.

Seitzinger, S.P., 1988, Denitrification in freshwater and coastal marine ecosystems: ecological and geochemical significance: Limnology and Oceanography, v. 33, p. 702-724.

Seitzinger, S.P., Harrison, J.A., Böhlke, J.K., Bouwman, A.F., Lowrance, R., Peterson, B., Tobias, C., and Drecht, G.V., 2006, Denitrification across landscapes and waterscapesA synthesis: Ecological Applications, v. 16, no. 6, p. 2064 2090.

Seitzinger, S.P., and Kroeze, C., 1998, Global distribution of nitrous oxide production and $\mathrm{N}$ inputs in freshwater and coastal marine ecosystems: Global Biogeochemical Cycles, v. 12, p. 93-113.

Seitzinger, S.P., and Nixon, S.W., 1985, Eutrophication and the rate of denitrification and nitrous oxide production in coastal marine sediments: Limnology and Oceanography, v. 30 , p. $1332-1339$.

Seitzinger, S.P., Nixon, S.W., and Pilson, M.E.Q., 1984, Denitrification and nitrous oxide production in a coastal marine ecosystem: Limnology and Oceanography, v. 29, p. 73-83.
Silliman, B.R., and Bertness, M.D., 2004, Shoreline development drives invasion of Phragmites australis and the loss of plant diversity on New England salt marshes: Conservation Biology, v. 18, no. 5, p. 1424-1434.

Smith, C.J., Delaune, R.D., and Patrick, W.H., 1985, Fate of riverine nitrate entering an estuary-I. Denitrification and nitrogen burial: Estuaries, v. 8, p. 15-21.

Smith, C.J., Wright, M.F., and Patrick, W.H., Jr., 1983, The effect of soil redox potential and $\mathrm{pH}$ on the reduction and production of nitrous oxide: Journal of Environmental Quality, v. 12, no. 2, p. 186-188.

Tiedje, J.M., Simkins, Stephen, and Groffman, P.M., 1989, Perspectives on measurement of denitrification in the field including recommended protocols for acetylene based methods: Plant and Soil, v. 115, p. 261-284.

Tobias, C.R., Harvey, J.W., and Anderson, I.C., 2001, Quantifying groundwater discharge through fringing wetlands to estuaries - Seasonal variability, methods comparison, and implications for wetland-estuary exchange: Limnology and Oceanography, v. 46, p. 604-615.

Tobias, C.R., and Neubauer, S.C., 2009, Salt marsh biogeochemistry-An overview, in Perillo, G., and others, eds., Coastal wetlands-An integrated ecosystem approach: New York, N.Y., Elsevier, p. 445-492.

Valiela, Ivan, and Bowen, J.L., 2002, Nitrogen sources to watersheds and estuaries - Role of land cover mosaics and losses within watersheds: Environmental Pollution, v. 118, no. 2, p. 239-248.

Valiela, Ivan, Cole, M.L., McClelland, James, Hauxwell, Jennifer, Cebrian, Just, and Joye, S.B., 2000, Role of salt marshes as part of coastal landscapes, in Weinstein, M.P., and Kreeger, D.A., eds., Concepts and controversies in tidal marsh ecology: Dordrecht, Kluwer, p. 23-28.

Valiela, Ivan, Costa, Joseph, Foreman, Kenneth, Teal, J.M., Howes, Brian, and Aubrey, David, 1990, Transport of groundwater-borne nutrients from watersheds and their effects on coastal waters: Biogeochemistry, v. 10, p. 177197.

Weier, K.L., Doran, J.W., Power, J.F., and Walters, D.T., 1993, Denitrification and the dinitrogen/nitrous oxide ratio as affected by soil water, available carbon, and nitrate: Soil Science Society of America Journal, v. 57, no. 1, p. 66-72.

Wigand, C., McKinney, R.A., Chintala, M.M., Charpetier, M.A., and Groffman, P.M., 2004, Denitrification enzyme activity of fringe salt marshes in New England (USA): Journal of Environmental Quality, v. 33, p. 1144-1151.

Wood, E.D., Armstrong, F.A.J., and Richards, F.A., 1967, Determination of nitrate in sea water by cadmium-copper reduction to nitrite: Journal of the Marine Biological Association of the United Kingdom, v. 47, p. 23-31. 
Prepared by the Pembroke Publishing Service Center.

For more information concerning this report, contact:

Director

U.S. Geological Survey

Maine Water Science Center

196 Whitten Road

Augusta, ME 04330

dc_me@usgs.gov

or visit our Web site at:

http://me.water.usgs.gov 
